\title{
An updated checklist of mosquito species (Diptera: Culicidae) from Madagascar
}

\author{
Michaël Luciano Tantely ${ }^{1, *}$, Gilbert Le Goff ${ }^{2}$, Sébastien Boyer $^{1}$, and Didier Fontenille ${ }^{3}$ \\ 1 Laboratoire d'Entomologie Médicale, Institut Pasteur de Madagascar, Antananarivo 101, Madagascar \\ 2 IRD UMR MIVEGEC, 34394 Montpellier and IRD La Réunion-GIP CYROI, 97490 Sainte Clotilde, La Réunion, France \\ 3 IRD UMR MIVEGEC, 34394 Montpellier and Institut Pasteur du Cambodge 5, BP 983, Blvd. Monivong, 12201 Phnom Penh, Cambodia
}

Received 28 September 2015, Accepted 16 March 2016, Published online 21 April 2016

\begin{abstract}
An updated checklist of 235 mosquito species from Madagascar is presented. The number of species has increased considerably compared to previous checklists, particularly the last published in 2003 (178 species). This annotated checklist provides concise information on endemism, taxonomic position, developmental stages, larval habitats, distribution, behavior, and vector-borne diseases potentially transmitted. The 235 species belong to 14 genera: Aedeomyia (3 species), Aedes (35 species), Anopheles (26 species), Coquillettidia (3 species), Culex (at least 50 species), Eretmapodites (4 species), Ficalbia (2 species), Hodgesia (at least one species), Lutzia (one species), Mansonia (2 species), Mimomyia (22 species), Orthopodomyia (8 species), Toxorhynchites (6 species), and Uranotaenia (73 species). Due to non-deciphered species complexes, several species remain undescribed. The main remarkable characteristic of Malagasy mosquito fauna is the high biodiversity with 138 endemic species (59\%). Presence and abundance of species, and their association, in a given location could be a bio-indicator of environmental particularities such as urban, rural, forested, deforested, and mountainous habitats. Finally, taking into account that Malagasy culicidian fauna includes 64 species $(27 \%)$ with a known medical or veterinary interest in the world, knowledge of their biology and host preference summarized in this paper improves understanding of their involvement in pathogen transmission in Madagascar.
\end{abstract}

Key words: Mosquitoes, Taxonomy, Biology, Vectors, Madagascar.

Résumé - Liste à jour des espèces de moustiques (Diptera: Culicidae) de Madagascar. Une liste mise à jour des 235 espèces de moustiques de Madagascar est présentée. Le nombre d'espèces a considérablement augmenté par rapport à celui donné dans les listes précédentes, en particulier la dernière, publiée en 2003 (178 espèces). Cette liste fournit des informations concises sur l'endémisme, la position taxonomique, les stades de développement, les gîtes larvaires, la distribution, le comportement des moustiques, et aussi sur les maladies potentiellement transmises par les moustiques vecteurs. Ces 235 espèces sont réparties dans 14 genres : Aedeomyia ( 3 espèces), Aedes (35 espèces), Anopheles (26 espèces), Coquillettidia ( 3 espèces), Culex (au moins 50 espèces), Eretmapodites (4 espèces), Ficalbia (2 espèces), Hodgesia (au moins une espèce), Lutzia (une espèce), Mansonia ( 2 espèces), Mimomyia (22 espèces), Orthopodomyia ( 8 espèces), Toxorhynchites (6 espèces), Uranotaenia (73 espèces). En raison de complexes d'espèces non résolus, plusieurs espèces sont toujours non décrites. La principale caractéristique remarquable de la faune malgache de moustiques est la grande biodiversité avec 138 espèces endémiques $(59 \%)$. La présence et l'abondance des espèces, et leur association dans un endroit donné, pourrait être un bio-indicateur des particularités environnementales telles que les habitats urbains, ruraux, forestiers, déboisés et montagneux. Enfin, compte tenu que la faune malgache de moustiques comprend 64 espèces $(27 \%)$ ayant un intérêt médical ou vétérinaire connu dans le monde, la connaissance de leur biologie et de leur préférence d'hôtes résumée dans le présent document permet de comprendre leur implication dans la transmission d'agents pathogènes à Madagascar.

*Corresponding author: Iucinambi@pasteur.mg

This is an Open Access article distributed under the terms of the Creative Commons Attribution License (http://creativecommons.org/licenses/by/4.0), which permits unrestricted use, distribution, and reproduction in any medium, provided the original work is properly cited. 


\section{Introduction}

The first information about Malagasy mosquitoes dated from the second half of the 19th century, when the presence of Aedes aegypti (as Culex insatiabilis) (Linnaeus) and Culex quinquefasciatus Say (as C. anxifer) was recorded by Bigot (1859) [12]. The first description of a Malagasy mosquito species was made by a pioneer of tropical medicine, the parasitologist Alphonse Laveran, in 1900 and involved a new Anopheles (An. coustani Laveran) [137]. In 1920, Enderlein [81] and Edwards [75] were the first to report mosquito collections from Madagascar and the Mascareignes Islands in the Indian Ocean [75]. This observation highlights that knowledge about Malagasy Culicidae fauna was closely related to human health, like during health campaigns during World War II [53, 54, 228, 229] and then in studies by the Institut de Recherche Scientifique de Madagascar (IRSM) and Institut Pasteur de Madagascar (IPM). These institutes were responsible for further research on the mosquitoes of Madagascar in relation to malaria, filariasis, and arbovirus control programs. A large number of species were described by Doucet [63-68], Grjebine [103, 105-107], Brunhes [20-26], Brunhes and collaborators [28-31], Ravaonjanahary [183, 184], and Rodhain and Boutonnier [192, 193]. Grjebine presented a monograph of 26 Anopheles species [108], Ravaonjanahary studied the biogeography of the 23 Aedes species [182], Fontenille published the first checklist which included 177 Malagasy species [85], and Brunhes \& Hervy published a monograph of Orthopodomyia species of the Ethiopian region [27]. The last revised checklist was published in 2003 and included 178 mosquito species [70]. Considering the medical and nuisance impact of the genera Aedes, Anopheles, and Culex in pathogen transmission, the checklists included more species belonging to these genera $[70,85]$.

Species belonging to the genera Uranotaenia [51], Toxorhynchites [190], subgenus Aedes (Neomelaniconion) [143] and Aedeomyia [33] were recently described.

The annotated checklist was developed with the aim of updating the list of Malagasy mosquito species, to eliminate species erroneously mentioned in Internet reference such as http://mosquito-taxonomic-inventory.info/ [119], Arthropodes d'intérêt médical (Arim: http://www.arim.ird.fr/) [5]; and the Walter Reed Biosystematics Unit (WRBU) at the Smithsonian Institution WRBU: http://wrbu.si.edu/ [244], and to provide more knowledge on their systematics, bioecology, vectorial capacity, distribution, and vector-borne disease status.

This list was compiled using our own observations, and Internet and bibliographic references. The Culicidae mosquito fauna includes 235 species within 14 genera. The present taxon identifications are based on formally recognized genera, and subgenera. Their abbreviations follow taxonomic nomenclature from A Catalog of the Mosquitoes of the World [132], its supplements [131, 235, 236] and Reinert [188, 189], and Wilkerson et al. [241] for the names of tribe Aedini. The author is given at first mention of a species.

Each species can be cited as follows: genus (subgenus) species, author(s) and date of first description, new name according to Wilkerson et al. [241], author(s) and date of first mention in Madagascar, endemism, development stages, larval habitats, distribution, trophic behavior, and vector-borne diseases potentially transmitted. The relationship between the species distribution and the importance of Malagasy biodiversity has been discussed, raising questions about the mosquito's evolution and differentiation.

\section{Presentation of Malagasy mosquitoes}

\subsection{Genus Anopheles Meigen, 1818}

The genus Anopheles is subdivided into eight subgenera. The subgenera Anopheles and Cellia are present in Madagascar. The subgenus Anopheles is represented by more than 183 species in the world [119]. In Madagascar, three species are present and they belong to the Myzorhynchus Series. One is an endemic species. The subgenus Cellia is represented by 224 species in the world. In Madagascar, 23 species occur. Ten are endemic, and one species (Anopheles mascarensis de Meillon) is present in Madagascar and in the Comoros Islands. Anopheles (Ano.) obscurus (Grünberg), An. (Cel.) argenteolobatus (Gough), An. (Cel.) christyi (Newstead \& Carter), An. (Cel.) confusus Evans \& Leeson, An. (Cel.) marshallii (Theobald), An. (Cel.) nili (Theobald), and An. (Cel.) theileri Edwards are absent from Madagascar (this study, [5]) but were ranked by WRBU among the mosquito species found on the island [244]. Three names of doubtful validity (An. arnoulti, An. courdurieri, and An. fuscicolor soalalaensis), regarded as nomen dubium by Brunhes et al. [32], are not listed in this document.

\subsubsection{Subgenus Anopheles Meigen, 1818}

\section{Myzorhynchus Series [78] \\ Group Coustani [186]}

\section{- Anopheles (Anopheles) coustani Laveran, 1900 [137]} Laveran, 1900 [137]

In Madagascar, larval habitats are cattle hoof prints [63], ponds, swamps [103], rivers, streams, canals, rice fields [67], lakes, rock holes, flushing holes [140], and pools of brackish water [108]. Occurs in all biogeographic domains [85, 108]. Zoo-anthropophilic species, involved in transmission of Plasmodium falciparum and P. vivax [169], Wuchereria bancrofti [20], Setaria sp. [23], endemic Périnet virus (PERV) [85], Rift Valley fever virus (RVFV) [181], and West Nile virus (WNV) [152]. Babanki virus (BABV) was found in a mixed batch of mosquito species, including An. coustani, collected in Périnet [85]. In Africa, involved in transmission of Zika virus (ZIKV) [56]. Oocysts and sporozoite stage of Plasmodium, causing human malaria, were reported [239].

\section{- Anopheles (Anopheles) fuscicolor van Someren, 1947 [228]}

van Someren, 1947 [228]

Endemic. Eggs undescribed. Larval habitats are ponds, streams, rice fields, irrigation canals, marshes, ponds, lakes, rivers, water bodies, and lagoons [108]. Occurs in all Malagasy biogeographic domains [108]. BABV, RVFV, and PERV were 


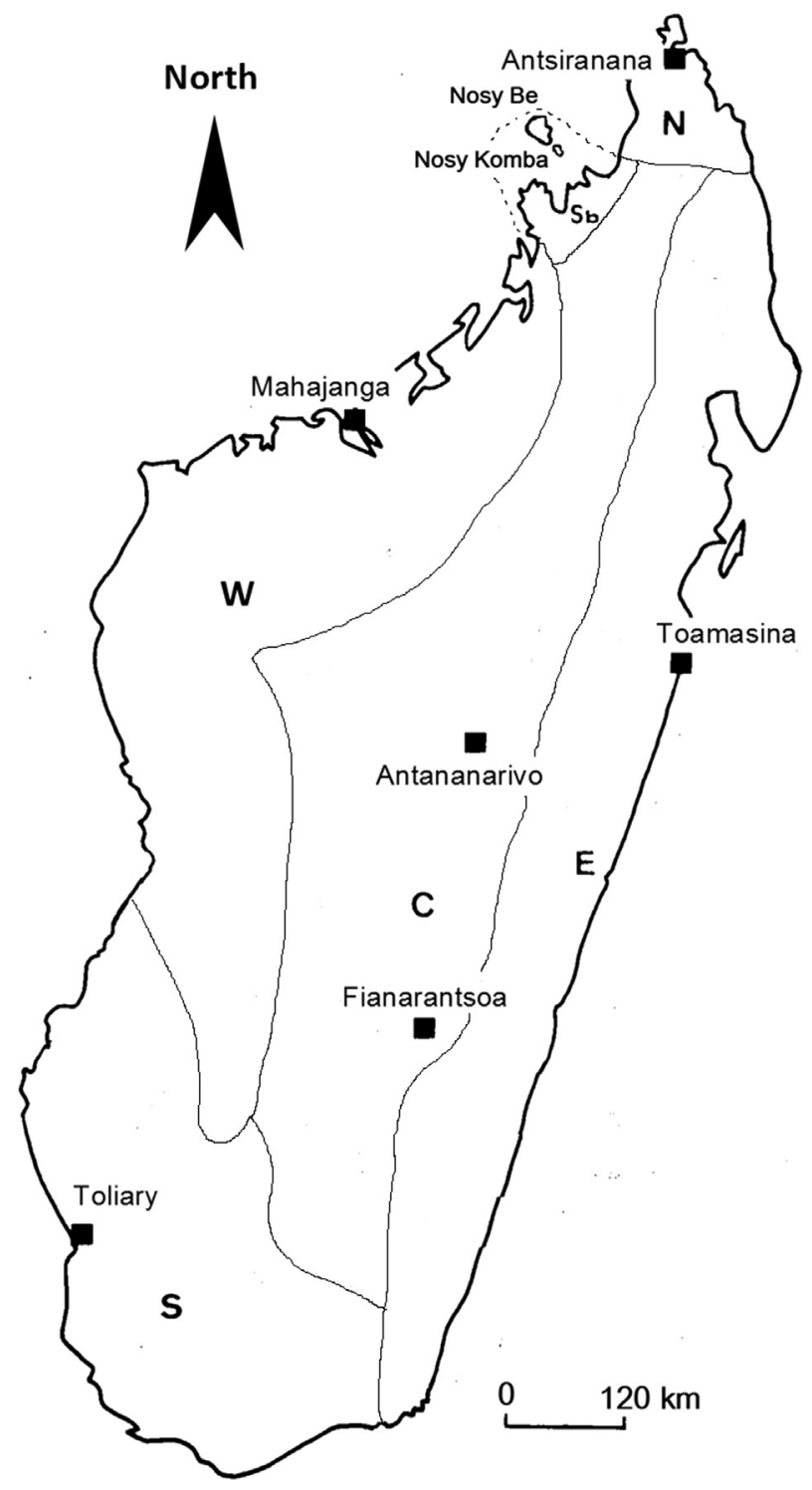

Figure 1. Map showing the biogeographic domains of Madagascar. N: northern domain; W: western domain; S: southern domain; E: eastern domain; C: central domain and Sb: Sambirano area [46].

isolated from a mixed batch of mosquito species, including Anopheles fuscicolor [85]. Wuchereria bancrofti stage III found [23].

\section{- Anopheles (Anopheles) tenebrosus Dönitz, 1902 [61]} Grjebine, 1956 [105]

In Madagascar, larval habitats are rice fields, ponds, swamps, and streams. Occurs in the Sambirano (Nosy Be), northern, central, and western biogeographic domains [108]. Not involved in disease transmission in Madagascar, but involved in transmission of human malaria in Africa [3].

\subsubsection{Subgenus Cellia Theobald, 1902}

Pyretophorus Series [78]

Gambiae Complex
This complex is represented by eight species in Africa. Three of them occur in Madagascar: Anopheles gambiae Giles, An. arabiensis Patton, and An. merus Dönitz. All developmental stages of these three species have been described. Anopheles gambiae and An. arabiensis grow in freshwater breeding sites. Anopheles merus grows in brackish water and occurs in the southern and western biogeographic domains of Madagascar [146]. These three species are vectors of Plasmodium sp. [91, 146]. They are also involved in transmission of Wuchereria bancrofti [20]. In Africa, these three species were found naturally infected with Mengo virus (MgV) [85], Ganjam virus (GANV) [101], Tataguine virus (TATV), Ilesha virus (ILEV) [45], O'nyong-nyong virus (ONNV) [231], and Bwamba virus (BWAV) [47] (Fig. 1).

\section{- Anopheles (Cellia) arabiensis Patton, 1905 [172]}

Chauvet \& Déjardin, 1968 [37]

In Madagascar, it has karyotypes similar to those of east Africa [179], shows high and low degrees of zoophilic and anthropophilic behavior, respectively [179], and occurs in all biogeographic domains [36, 146].

\section{- Anopheles (Cellia) gambiae Giles, 1902 [97]}

Chauvet \& Déjardin, 1968 [37]

On the African mainland, five chromosomal forms, partially panmictic $[43,44]$ and two DNA ribosomal molecular forms, were described [83]. These molecular forms $\mathrm{M}$ and $\mathrm{S}$ have recently been elevated to the status of species and are named respectively: Anopheles coluzzii Coetzee \& Wilkerson and An. gambiae s.s. [42]. In Madagascar, Anopheles gambiae has molecular forms similar to those of east Africa [142, 146, 209] and the species identified is Anopheles gambiae s.s. This species is characterized by a high degree of anthropophilic behavior [179] with notable exceptions [69]. In Madagascar, present in all biogeographic domains [36, 146, 209].

\section{- Anopheles (Cellia) merus Dönitz, 1902}

Chauvet, 1968 [36]

Larval habitats are brackish water in the Mangatsa area, and crab holes in Betsiboka estuary (in the Mahajanga region), in the western and southern domains, and in the extreme south of Madagascar [146, 170]. Major vector of human Plasmodium in local scale [146].

Myzomyia Series (Christophers, 1924) [39]

\section{- Anopheles (Cellia) brunnipes (Theobald, 1910) [220]} Doucet, 1951

Eggs undescribed. In Madagascar, larval habitats are ponds, along riverbanks, streams, road drains, ditches, nurseries, and rice fields [108]. Occurs in the western, central, and eastern domains [108]. WNV was isolated from specimens caught in Manambo area [85]. In the Ethiopian region, it has a wide distribution, and oocysts and sporozoites of Plasmodium causing human malaria were reported for this species [239].

- Anopheles (Cellia) flavicosta Edwards, 1911 [72] Coz, Grjebine \& Hamon, 1960 [49] 
Eggs undescribed. In Madagascar, larval habitats are ponds, rivers, streams, and rice fields [108]. Occurs in all biogeographic domains $[85,108]$. In the Ethiopian region, it has a wide geographical distribution and is highly zoophilic, and occasionally feeds on humans [114]. Involved in transmission of Wuchereria bancrofti [16], Plasmodium sp., and Middelburg virus (MIDV) [1, 239].

Group Funestus (Harbach 2004) [116]

Subgroup Funestus (Gillies and de Meillon, 1968) [98]

\section{- Anopheles (Cellia) funestus Giles, 1900 [95]}

Laveran, 1904 [138]

The Group Funestus includes 10 species. In Madagascar, only the species Anopheles funestus is present. Larval habitats are irrigation canals [67], lakes, ponds, pools, marshes, riverbanks, streams, irrigation drains, and rice fields [108]. Occurs in all Malagasy biogeographic domains [85, 108]. Anthropophilic species and major vector of malaria parasite [91] and involved in transmission of Wuchereria bancrofti and Setaria sp. [23]. In the Ethiopian region, widely distributed and involved in transmission of Pongola virus (PGAV) [47], ONNV, BWAV, Nyando virus (NDV) [151], Chikungunya virus (CHIKV), Wesselsbron virus (WSLV), Bozo virus (BOZOV), Akabane virus (AKAV), Tanga virus (TANV), TATV, and Orungo virus (ORUV) [1].

Cellia Series (Christophers, 1924) [39]

Group Squamosus Grjebine, 1966 [108]

\section{- Anopheles (Cellia) cydippis de Meillon, 1931 [52]} Doucet, 1951 [68]

Adults are morphologically similar to Anopheles squamosus Theobald. Its larval stages differ from those of Anopheles squamosus, in having simple external clypeal seta (3-C), plumose, or with few short or long branches. In Madagascar, larval habitats are lakes, ponds, marshes, riverbanks, streams, pools, water containing iron hydroxide, irrigation drains, tanks, cement basins [108], and watering holes [140]. Occurs in all biogeographic domains [85, 108]. Not involved in disease transmission.

\section{- Anopheles (Cellia) squamosus Theobald, 1901}

Laveran, 1904 [138]

Eggs undescribed. Its larval stages differ from those of Anopheles cydippis, in having a dendroid external clypeal seta (3-C) with one trunk divided into eight branches. In Madagascar, larval habitats are marshes [103], ponds, rice fields [111], irrigation drains, pools, brackish water pools, rivers, and lagoons [108]. Occurs in all biogeographic domains [85, 108]. Zoophilic species (cattle, sheep, and poultry) [210] and involved in transmission of RVFV [181], Andasibe virus (ANDV) [85], Bluetongue virus (BTV) [4], and Wuchereria bancrofti [23]. In Africa, zoophilic species [114] and involved in transmission of Birao virus (BIRV) [45] and BABV [1].

\section{- Anopheles (Cellia) pharoensis Theobald, 1901} Ventrillon, 1905 [75]

In Madagascar, larval habitats are cattle hoof prints, grasslands [63], ponds, rice fields [67], lagoons (fresh water), drains, irrigation, nurseries, lakes, ponds, marshes, riverbanks, streams, and water containing iron hydroxide [108]. Occurs in all biogeographic domains (except the Sambirano area) $[85,108]$. Not involved in disease transmission. In Africa, occurs in Ethiopian region, Egypt, and Eritrea. Essentially zoophilic (especially cattle) and may feed on birds [114]. Involved in transmission of BIRV [45], RVFV [147], Ngari virus (NGAV), Bangui virus (BGIV) [101], BABV, WSLV, Sanar virus (SANV) [1], Wuchereria bancrofti [16], and Plasmodium sp. (with oocysts and sporozoites) [239].

Neocellia Series (Christophers, 1924) [39]

\section{- Anopheles (Cellia) maculipalpis Giles, 1902 [97] Monier, 1937 [167]}

Eggs undescribed. In Madagascar, larval habitats are marshes, ponds, riverbanks, streams, wetlands, lakes, irrigation drains, tanks, cement tanks, tire tracks, cattle hoof prints, plant nurseries, and rice fields [108]. Occurs in all biogeographic domains $[85,108]$ and may be attracted to humans and livestock [85] (Luciano Tantely, unpublished observation). Involved in transmission of WNV [85]. In Africa, involved in transmission of Wuchereria bancrofti [16] and Plasmodium sp. (oocysts or sporozoites) [239].

\section{- Anopheles (Cellia) rufipes (Gough, 1910) [102] \\ Wilson, 1947 [243]}

In Madagascar, larval habitats are lakes, ponds, pools, marshes, wetlands, containing water with more or less iron hydroxide, streams, puddles, rock holes, tanks, cement tanks, nurseries, and rice fields [108]. Occurs in all Malagasy biogeographic domains $[85,108,185]$. May be attracted to humans [85] and livestock (Luciano Tantely, unpublished observation); but not involved in disease transmission. In Africa, zoophilic species (particularly to large mammals) [114] and involved in transmission of CHIKV [57], WSLV, and Gomoka virus (GOMV) [1] and Plasmodium sp. (oocysts or sporozoites) [239].

\section{- Anopheles (Cellia) pretoriensis (Theobald, 1903) [216] Grjebine, 1953 [103]}

In Madagascar, larval habitats are rock holes [112], marshes, ponds, riverbanks, streams, puddles, irrigation drains, and rice fields [108]. Occurs in all Malagasy biogeographic domains [85, 108]. Anthropophilic species [108] and may be attracted to livestock (Luciano Tantely, unpublished observation), but not involved in disease transmission. In Africa, involved in transmission of WSLV and NGAV in Senegal [1], and Plasmodium sp. (oocysts or sporozoites) [239].

Series Neomyzomyia (Christophers, 1924) [39]

Group Mascarensis (Harbach, 1994) [116]

\section{- Anopheles (Cellia) mascarensis de Meillon, 1947 [54]}

Endemic in Madagascar and Comoros archipelagos. Eggs undescribed. In Madagascar, it was confused with An. (Cellia) marshallii (African mainland species) [108]. Larval habitats are streams [103], lakes, ponds, pools, marshes, riverbanks, backwaters, irrigation drains, nurseries, brackish water, lagoons [108], wetland pools [18], and rice fields [191]. Occurs in 
Sambirano domain (Nosy Be, Nosy Komba) [90], and in all Malagasy biogeographic domains [85, 108]. May be attracted to livestock, humans, and poultry [141, 210]. Secondary or major vector of local importance for malaria [87, 141, 146, 154]. Found naturally infected with NGAV [85] and Wuchereria bancrofti [23].

Group Pauliani (Grjebine, 1966) [108]

\section{- Anopheles (Cellia) grassei Grjebine, 1953 [104]} Grjebine, 1953 [104]

Endemic. Only species belonging to the Grassei Group. Morphologically close to Anopheles radama de Meillon. Larval habitats are marshes, ponds, backwaters, coastal rivers, streams, bodies of water due to small dams, and tree holes [85]. Occurs in the eastern [108] and western domains [15, 170]. May be caught in human landing catches [85], but is not involved in transmission of vector-borne diseases.

\section{- Anopheles (Cellia) grenieri Grjebine, 1964 [107]} Grjebine 1964 [107]

Endemic. Only the larval stages were described [107]. Larval habitats are streams flowing through forest and harvested rice fields [108]. Occurs in the eastern wetland area [108] and not involved in disease transmission.

\section{- Anopheles (Cellia) milloti Grjebine \& Lacan, 1953} [103]

Grjebine \& Lacan, 1953 [103]

Endemic. Eggs undescribed. Larval habitats are holes, grassy ponds, lakes, ponds, riverbanks of streams, and lakes, water containing iron hydroxide, irrigation drains [108, 112], swamps, and marshland [18]. Occurs in all Malagasy biogeographic domains (except the southern domain) [108]. Adult biology unknown. Not involved in transmission of vectorborne diseases.

\section{- Anopheles (Cellia) pauliani Grjebine, 1953 [103]} Grjebine, 1953 [103]

Endemic. Eggs undescribed. Larval habitats are lakes, ponds, pools, marshes, ponds, rivers, streams, and rice fields [108]. Occurs in the Sambirano area (Nosy Komba) [90], and all Malagasy biogeographic domains [85, 108, 185], prefers to feed on domestic ruminants, but it may also feed on humans, birds, rodents, and lemurs [108]. RVFV and ANDV were found in a mixed batch of mosquito species, including An. pauliani, caught in Périnet [85]. Involved in transmission of WNV [152] and Wuchereria bancrofti [23].

\section{- Anopheles (Cellia) radama de Meillon, 1943 [53]} de Meillon, 1943 [53]

Endemic. Eggs undescribed. Morphologically close to Anopheles grassei Grjebine. Larval habitats are ponds [66], streams, bodies of water, rivers, and volcanic crater lakes [108]. Occurs in the Sambirano area (in Nosy Be, Nosy Komba) [90], the northern [85, 108], western [185], and eastern domains [66]. Not involved in transmission of vector-borne diseases.
Group Ranci (Grjebine, 1966) [108]

Subgroup Ranci (Grjebine, 1966) [108]

\section{- Anopheles (Cellia) griveaudi Grjebine, 1960 [106]}

Grjebine, 1960 [106]

Endemic. Only the adult female was described [106] and is known only from a single specimen collected in 1956, by Griveaud, in a mercury-vapor lamp, in Ankaratra massif, in the central biogeographic domain [108].

\section{- Anopheles (Cellia) ranci Grjebine, 1953 [103]}

Grjebine, 1953 [103]

Endemic. Eggs undescribed. Larval habitats are pools, riverbanks, streams, and rice fields [108]. Occurs in the northern and eastern biogeographic domains [85, 108]. Adult biology unknown. Not involved in transmission of vector-borne diseases.

Subgroup Roubaudi (Grjebine, 1966) [108]

\section{- Anopheles (Cellia) lacani Grjebine, 1953 [103]}

Grjebine, 1953 [103]

Endemic. Adult male and eggs undescribed. Larval habitats are streams flowing through natural forest areas [108, 207]. Occurs in the Mandraka forest of the eastern wetland domain [108] and in the Anjozorobe-Angavo forest corridor, in the subhumid area of the central biogeographic domain [210]. Adult biology unknown. Not involved in transmission of vector-borne diseases.

\section{- Anopheles (Cellia) notleyi van Someren, 1949 [229]}

van Someren, 1949 [229]

Endemic. Eggs undescribed. Larval habitats are streams flowing through forest areas [108]. Occurs only in Sakaramy area, Antsiranana province, in the northern domain [108] and in Farankaraina forest, near the Masoala National Park, in the eastern domain (Gilbert Le Goff, unpublished observation). Adult biology unknown. Not involved in transmission of vector-borne diseases.

\section{- Anopheles (Cellia) roubaudi Grjebine, 1953 [103]} Grjebine, 1953 [103]

Endemic. Eggs undescribed. Wing morphology similar to that of Anopheles flavicosta Edwards, An. notleyi, An. lacani [108]. Larval habitats are streams flowing through medium altitude forests (900 m asl), like Périnet (Gilbert Le Goff, unpublished observation). Occurs in the humid forest of the eastern domain [108]. Adult biology unknown. Not involved in transmission of vector-borne diseases.

\subsection{Genus Aedeomyia Theobald, 1901 [213]}

This genus is subdivided into two subgenera: Aedeomyia and Lepiothauma. It is represented by seven species distributed in Afrotropical, Australasian, Oriental, and Neotropical regions $[33,117]$. Three species occur in Madagascar: two of them are Malagasy endemic species [33]. Larvae of this genus often breed in permanent water with abundant aquatic vegetation. Little is known about adult biology. 


\subsubsection{Subgenus Aedeomyia Theobald, 1901}

This subgenus is represented by six species in the world. Two species are endemic to Madagascar. Species of genus Aedeomyia has been documented to feed on birds [33].

- Aedeomyia (Aedeomyia) madagascarica Brunhes, Boussès, \& da Cunha Ramos, 2011 [33]

Brunhes, Boussès, \& da Cunha Ramos, 2011 [33]

Endemic. Known only in the adult stages (male and female) [33]. Biology unknown. Collected from the type locality (forest of Ivoloina, Toamasina) [33] and in the western domain [15]. Ornithophilic around Lake Kinkony [211] and found naturally infected with $\mathrm{WNV}$ in Mitsinjo district [152].

\section{- Aedeomyia (Aedeomyia) pauliani Grjebine, 1953 [103]} Grjebine, 1953 [103]

Endemic. Collected only once, known only from the type locality (Lake Zanavorono, Ambila Lemaitso), and only from the larval stages collected from the banks of a lake in Ambila Lemaitso, on the Pangalanes Canal, in the eastern domain of Madagascar [22].

\subsubsection{Subgenus Lepiothauma Enderlein, 1923}

This subgenus is monotypic.

\section{- Aedeomyia (Lepiothauma) furfurea (Enderlein, 1923)} [82]

Doucet, 1950 [65]

Eggs undescribed. Wide spatial distribution in Africa and Madagascar. In Madagascar, larvae were found breeding in muddy swamps, rice fields, ponds [67], crater lakes [108], and fishponds [33]. Collected for the first time by Paulian from Antsohihy of the western domain [65]; also found in central and eastern domains [33]. Not involved in disease transmission in Madagascar.

\subsection{Genus Aedes Meigen, 1818}

Aedes is the largest genus in the subfamily Culicinae with 930 species [241]. Thirty-eight subgenera were reported by Knight and Stone in 1977 [132]. This genus was recently subdivided into 74 subgenera, which was restored to its status prior to the year 2000 [241]. According to Wilkerson et al. [241], 12 subgenera are present in Madagascar. These subgenera are represented by 35 species, 18 species are endemic to Madagascar, and two species are found in Madagascar and in the Comoros archipelago.

\subsubsection{Subgenus Aedimorphus Theobald, 1903}

In Madagascar, this subgenus includes eight species, three are endemic. This list and Arim [5] did not include Aedes (Aedimorphus) ovazzai that may be erroneously reported to be present on the island by WRBU [244]. In Africa, species were involved in transmission of RVFV [93, 147].

\section{- Aedes (Aedimorphus) albodorsalis Fontenille \&} Brunhes, 1984

Fontenille \& Brunhes, 1984 [86]

Endemic. Only the adult female has been described [86]. Found in the eastern [86] and western bioclimatic domains [15]. Anthropophilic, diurnal, seems closely related to northeastern forest areas [86]. Not involved in disease transmission in Madagascar.

\section{- Aedes (Aedimorphus) durbanensis (Theobald, 1903)} Ravaonjanahary, 1978 [182]

Pupal stages undescribed. In Madagascar, larval habitats are ponds, grassy bottom-land, and ditches [182]. Occurs in southern and western Malagasy domains [85, 170]. No medical and veterinary importance in Madagascar. However, was found naturally infected with RVFV in Kenya [168].

\section{- Aedes (Aedimorphus) domesticus (Theobald, 1901)} Doucet, 1951 [67]

Only Malagasy species belonging to the Group Domesticus [80]. Larval stages morphologically close to Aedes leptolabis Edwards which is absent from Madagascar [230]. In Madagascar, larval habitats are puddles near the sea [67]. Presence reported in Madagascar by Doucet [67] in Vangaindrano (eastern domain) but never confirmed. In Africa, involved in transmission of Bunyamwera virus (BUNV) in Cameroon [1].

\section{- Aedes (Aedimorphus) fowleri (de Charmoy, 1908)}

Doucet, 1950 [65]

Egg and pupal stages undescribed. In Madagascar, larval habitats are rice fields, ponds, rock holes, rock crevices, and boreholes [103]. Occurs in all Malagasy biogeographic domains with the exception of the north $[65,85,170]$. Not involved in disease transmission in Madagascar. In Africa, zoophilic and would rather feed on livestock and birds [114]. Involved in transmission of Bagaza virus (BAGV) [58], ZIKV, Kedougou virus (KEDV), Simbu viruses (SIMV), PGAV, RVFV [1], and Setaria sp. [16].

\section{- Aedes (Aedimorphus) dalzieli (Theobald, 1910)}

Ravaonjanahary, 1978 [182]

Egg and pupal stages undescribed. Only Malagasy species belonging to the Group Abnormalis [80]. In Madagascar, larval habitats are rain puddles [182]. Occurs in southern and western domains [182]. Not involved in the transmission of disease in Madagascar. In Africa, zoophilic and may feed on cattle, birds, and bats [114]. Found naturally infected with RVFV [164], Dengue 2 virus (DENV-2) [223], CHIKV, BABV, MIDV, Ndumu virus (NDUV), BAGV, WSLV, WNV, Bouboui virus (BOUV), KEDV, BUNV, Shokwe virus (SHOV), NGAV, SIMV, PGAV [1], ZIKV [56], and Nematoda (undetermined species) [16].

\section{- Aedes (Aedimorphus) masoalensis Fontenille \& Brunhes, 1984}

Fontenille \& Brunhes, 1984 [86]

Endemic. Only the adult female was described [86]. Occurs in the eastern Malagasy domain. Diurnal and anthropophilic [86]. $\mathrm{MgV}$ was isolated from specimens caught in Toamasina [85]. 


\section{- Aedes (Aedimorphus) mathioti Fontenille \& Brunhes, 1984}

Fontenille \& Brunhes, 1984 [86]

Endemic. Only adult female was described [86]. Rare, occurs in the lowland forest of the eastern Malagasy domain (Onive river valley and region of Soanierana-Ivongo). Diurnal and anthropophilic [86]. Not involved in disease transmission.

\section{- Aedes (Aedimorphus) natronius Edwards, 1932 \\ Arim, 1959 [5]}

Egg and pupal stages undescribed. No literature has reported its presence in Madagascar. However, this species occurs in Toliara, southern domain, as shown on the labels of specimens stored at the Institut de Recherche pour le Développement (IRD) of Montpellier [5]. Biology unknown. Not involved in disease transmission in Madagascar. In Africa, arboreal and crepuscular species [113] and involved in transmission of Uganda S virus (UGSV) [59].

\subsubsection{Subgenus Catageiomyia Theobald, 1903}

Only one species belonging to the subgenus Catageiomyia is in Madagascar.

\section{- Aedes (Catageiomyia) argenteopunctatus (Theobald, 1901)}

Doucet, 1951 [67]

Eggs undescribed. In Madagascar, Group Argenteopunctatus is represented only by Aedes argenteopunctatus [80] which occurs in eastern and central domains [85, 182]. Known larval habitats in Madagascar: small pools of water near the ocean, in the Vangaindrano area [67]. Anthropophilic. Potential vector of Dakar Bat virus (DBV) [85]. In Africa, zoophilic and prefers to feed on domestic ruminants, but may also feed on humans [114]. Involved in transmission of Semliki Forest virus (SFV) [159], Nkolbisson virus (NKOV) [197], SHOV, MIDV [47], DENV-2 [223], CHIKV [57], WSLV, BUNV, PGAV, GOMV, NGAV [1], and Nematoda (undetermined species) [16].

\subsubsection{Subgenus Coetzeemyia Huang, Mathis, \& Wilkerson, 2010}

This subgenus was recently created by Huang et al. [126] and is monotypic.

\section{- Aedes (Coetzeemyia) fryeri (Theobald, 1912)}

Edwards, 1920 [75]

Egg and pupal stages undescribed. Subgenus was changed on several occasions. Presence reported in Madagascar by Edwards in 1920 [75]. Adult stage morphologically close to Aedes dufouri Hamon which is endemic to La Réunion and likely absent from Madagascar. In Madagascar, larval habits are rock holes [144] and its biology seems to be related to the presence of mangrove [182]. Occurs in the western and southern biogeographic domains [85]. Caught in abundance in human landing catches in the Morondava region. No medical and veterinary importance in Madagascar [85], but found naturally infected with Spondweni virus (SPOV) in a mixedspecies batch of mosquitoes in Mozambique [161].

\subsubsection{Subgenus Diceromyia Theobald, 1911}

In Madagascar, this subgenus is represented by five endemic species.

\section{- Aedes (Diceromyia) coulangesi Rodhain \& Boutonnier, 1982}

Rodhain \& Boutonnier, 1982 [192]

Endemic. Only the adult female and male were described to date [192]. Occurs in the Marovoay region (dry forest of Ampijoroa), in the western biogeographic domain [192]. Presence reported in the Montagne d'Ambre (northern biogeographic domain) and in Amboasary regions (southern biogeographic domain) [85]. Anthropophilic but no medical and veterinary importance in Madagascar [85].

\section{- Aedes (Diceromyia) grassei Doucet, 1951}

Doucet, 1951 [66]

Endemic. Egg, larval and pupal stages undescribed. Adult male morphologically close to Ae. sylvaticus [26]. Seems to occur only in the primary mountain forest of Moramanga and Périnet, in the eastern biogeographic domain [182]. No medical and veterinary importance in Madagascar.

\section{- Aedes (Diceromyia) madagascarensis van Someren, 1949}

van Someren, 1949, endemic [229]

Endemic. Adult male and female described [192]. Presence reported in all Malagasy biogeographic domains (except the southern domain) [85]. Diurnal and anthropophilic species and found naturally infected with WNV [85].

\section{- Aedes (Diceromyia) sylvaticus Brunhes, 1982}

Brunhes, 1982 [26]

Endemic. Only the adult male described. Morphologically close to Aedes grassei [26]. Collected only once and known only from the type locality (Ambohitranana forest, Masoala peninsula forest, eastern biogeographic domain) [26]. No medical and veterinary importance in Madagascar.

\section{- Aedes (Diceromyia) tiptoni Grjebine, 1953}

Grjebine, 1953 [103]

Endemic. Larval habitats are tree holes (mango tree, kapok tree, coconut tree, palm tree (Medemia nobilis) [182]. Occurs in all biogeographic domains of Madagascar [85, 170, 182]. Diurnal, anthropophilic, exophilic, and exophagic species [182]. May be attracted to domestic ruminants (goats and cattle) (Luciano Tantely, unpublished observation). No medical and veterinary importance in Madagascar.

\subsubsection{Subgenus Fredwardsius Reinert, 2000}

This subgenus includes only a single species.

\section{- Aedes (Fredwardsius) vittatus (Bigot, 1861)}

Doucet, 1951 [67]

Eggs undescribed. Formerly classified into the subgenus Stegomyia [201]. In Madagascar, larval habitats are especially rock holes [67] and rice fields [103]. Occurs in the Sambirano 
area (Nosy Be, Nosy Komba), western, central [85], eastern [67], and southern domains [182]. In Madagascar, human landing catches seem to be a productive method for collecting Aedes vittatus. No medical and veterinary importance in Madagascar. In Africa, zoophilic [114] and involved in the transmission of DENV-2 [223], CHIKV [57], ZIKV, Yellow Fever virus (YFV), WSLV, Saboya virus (SABV), NGAV, SIMV, PGAV, GOMV [1], and Sindbis virus (SINV) [47].

\subsubsection{Subgenus Mucidus Theobald, 1901}

This subgenus includes 11 species. The larvae of this subgenus are voracious predators of mosquito-associated species. Two species are present in Madagascar.

\section{- Aedes (Mucidus) scatophagoides (Theobald, 1901)}

Brunhes, 1968 [182]

Eggs undescribed. Presence reported for the first time in Madagascar by Brunhes in 1968 [182]. Larval habitats are warm temporary pools exposed to sunlight [182]. Occurs in the southern domain, particularly in the Antanimena area, in the semi-arid Androy region [182]. No medical and veterinary importance in Madagascar.

\section{- Aedes (Mucidus) mucidus (Karsch, 1887)}

Grjebine, 1955 [182]

Eggs undescribed. For the first time Grjebine (1955) reported the presence of Ae. mucidus in Périnet, eastern domain of Madagascar [182]. On the island, larval habitats are still unknown. No medical and veterinary importance in Madagascar.

\subsubsection{Subgenus Neomelaniconion Newstead, 1907}

This subgenus includes 28 species. Six species of Neomelaniconion are present in Madagascar. Five species of them are endemic and were described from specimens formerly called Ae (Neo.) palpalis that is absent from Madagascar [5, 143], but ranked among the mosquito species found on the island by WRBU [244]. Vertical transmission of RVFV was described in species belonging to this subgenus [147].

\section{- Aedes (Neomelaniconion) albiradius (Le Goff,}

Boussès, \& Brunhes, 2007)

Le Goff, Boussès, and Brunhes, 2007 [143]

Endemic. Only the adult female was described [143]. Sequence variations of the ribosomal DNA ITS2 consistent with morphological observations, indicating that this species belongs to the Group Sylvaticum [130]. Occurs in forest areas of the western (forest station Ampijoroa), central (forest relic near Anjiro), and south (degraded forest near Mahabo) regions [143]. No medical and veterinary importance in Madagascar.

\section{- Aedes (Neomelaniconion) belleci (Le Goff, Boussès, \& Brunhes, 2007)}

Le Goff, Boussès, \& Brunhes, 2007 [143]

Endemic. Eggs undescribed. Variations in ribosomal DNA ITS2 sequences consistent with morphological observations, indicating that this species belongs to the Group Circumluteolus [130].
No specific differentiation at the molecular level obtained between Ae. belleci and Ae. nigropterum. In Madagascar, larval habitats are temporary ponds characterized by being slightly brownish in color and full of dead leaves and located in forest areas of medium altitude (1000 m asl), near Ranomafana, in the eastern biogeographic domain [143]. Adult biology is unknown because adults were obtained only from larval rearing. No medical and veterinary importance in Madagascar.

\section{- Aedes (Neomelaniconion) circumluteolum (Theobald, 1908)}

Hamon, 1959 [182]

Pupal stages undescribed. Presence reported in Madagascar in the southern domain by Hamon in 1959 [182] and confirmed by molecular study which indicated that Malagasy and South African specimens share a common origin [130]. In Madagascar, larval habitats are temporary pools and puddles [28]. Occurs in coastal areas, in Nosy Be, in western, eastern, and central biogeographic domains [85]. Never captured in the semi-arid bioclimatic domains of south and south-west Madagascar [85]. Diurnal and anthropophilic species in forested areas [143]. Found naturally infected with WNV in Ampijoroa and involved in transmission or dissemination of this virus in Madagascar [85]. In Africa, prefers to feed on cattle and may feed occasionally on humans [114, 182]. Involved in transmission of SIMV [45], WNV [127], SPOV [160], and PGAV [1]. Found naturally [133] and experimentally [225] infected with RVFV.

\section{- Aedes (Neomelaniconion) fontenillei (Le Goff,} Boussès, \& Brunhes, 2007)

Le Goff, Boussès, and Brunhes, 2007 [143]

Endemic. Only adult stages (male and female) were described to date [143]. Sequence variations in ribosomal DNA ITS2 consistent with morphological observations, indicating that this species belongs to the Group Sylvaticum [130]. No specific differentiation at molecular level obtained between Ae. fontenillei and Ae. sylvaticum. In Madagascar, larval habitats may be small depressions in forest areas [143]. Adults collected from humans or using a hand-net in forest undergrowth. Only occurs in the Périnet forest, in the eastern biogeographic domain [143]. No medical and veterinary importance in Madagascar.

\section{- Aedes (Neomelaniconion) nigropterum (Le Goff,} Boussès, \& Brunhes, 2007)

Le Goff, Boussès, \& Brunhes, 2007 [143]

Endemic. Only the adult stages (male and female) were described to date [143]. Sequence variations in ribosomal DNA ITS2 consistent with morphological observations, indicating that this species belongs to the Group Circumluteolus [130]. No specific differentiation at molecular level obtained between this species and Ae. belleci. Only occurs in the Périnet forest, in the eastern biogeographic domain [143]. Adults were collected from humans or using a hand-net in forest undergrowth. No medical and veterinary importance in Madagascar. 
- Aedes (Neomelaniconion) sylvaticum (Le Goff, Boussès, \& Brunhes, 2007)

Le Goff, Boussès, \& Brunhes, 2007 [143]

Endemic. Only the adult stages (male and female) were described [143]. Sequence variations in ribosomal DNA ITS2 consistent with morphological observations, indicating that this species belongs to the Group Sylvaticum [130]. No specific differentiation at molecular level obtained between this species and Ae. fontenillei. Probably present in the northern and eastern biogeographic domains [143]. Occurs in Sainte-Marie island, on the eastern edge of Madagascar (from Sambava region to Manakara region), and in medium mountainous areas (900 $\mathrm{m}$ asl). Collected using a hand-net in forest undergrowth. No medical and veterinary importance in Madagascar.

\subsubsection{Subgenus Ochlerotatus Lynch Arribálzaga, 1891}

This subgenus includes 187 species in the world [241]. Only Ae. (Och.) ambreensis is present in Madagascar. The report of Aedes dufouri as present in Madagascar in Arim dataset [5] is doubtful as information on collection areas is not available. De facto this information was treated as an error. Aedes dufouri was described from Réunion Island and occurs on Europa island (French island in the Mozambique Channel) [99].

\section{- Aedes (Ochlerotatus) ambreensis Rodhain \& Boutonnier, 1983}

Rodhain \& Boutonnier, 1983 [193]

Endemic. Only the female was described [193]. Occurs in the Montagne d'Ambre, in the northern domain [85, 193]. Nocturnal, diurnal species and anthropophilic species, but also seems to feed on lemurs (Eulemur fulvus) [85]. Found naturally infected with unclassified virus (MMP 158 virus) in specimens collected at Montagne d'Ambre [85].

\subsubsection{Subgenus Polyleptiomyia Theobald, 1905}

In Madagascar, this subgenus includes only a single species.

- Aedes (Polyleptiomyia) albocephalus (Theobald, 1903) Grjebine, 1953 [103]

Eggs undescribed. In Madagascar, larval habitats are grassy bottom-land, watercourses, crab holes [103], grassy marshes, mangroves, and small collections of rainwater on salty soil connected to crab holes [182]. Occurs in all bioclimatic Malagasy domains (except the central domain) [85]. Anthropophilic [85], may be attracted to domestic ruminants (goat and cattle) (Luciano Tantely, unpublished observation). Not involved in disease transmission in Madagascar.

\subsubsection{Subgenus Skusea Theobald, 1903}

The species of this subgenus only occur in the western Indian Ocean region. This subgenus includes four species, and three of them occur in Madagascar with one endemic species to the island. In this subgenus, Aedes pembaensis, absent from Madagascar, was ranked among the mosquito species found on the island [5, 244].

\section{- Aedes (Skusea) cartroni (Ventrillon, 1906)}

Ventrillon, 1906 [234]

Endemic to Madagascar and the Comoros archipelago. Egg, larval and pupal stages undescribed. Considered to be a synonym of Aedes pembaensis [80], absent from Madagascar. Presence in Madagascar validated by comparing male genitalia of the two species [25]. Larval habitats are probably brackish waters [182], including mangrove and swamps [85]. Occurs in the western biogeographic and southern domains [25]. Adult mosquitoes, probably belonging to this species, were collected in the northern and eastern domains [85]. For Aedes cartroni, human landing catches were productive close to brackish water [85]. Found naturally infected with $\mathrm{MgV}$ [85].

\section{- Aedes (Skusea) lambrechti van Someren, 1971}

Ravaonjanahary and Brunhes, 1977 [184]

Eggs undescribed. First described from the granitic Seychelles. Its larval habitats are small collections of rainwater on salty soil communicating with crab holes [182]. Occurs in Nosy Be and Nosy Komba, in Sambirano area [85], and in the northern biogeographic domain to Antalaha [182]. Not involved in disease transmission.

\section{- Aedes (Skusea) moucheti Ravaonjanahary \& Brunhes, 1977}

Ravaonjanahary \& Brunhes, 1977 [184]

Endemic. Only the adult male was described [184]. Larval habitats are crab holes filled with brackish water [184]. Occurs in Nosy Be [184] and in the western domain [15]. Not involved in disease transmission.

\subsubsection{Subgenus Stegomyia Theobald, 1901}

This subgenus is represented by 126 species [241]. The Ethiopian region includes 59 species [125]. Only Aedes albopictus and Ae. aegypti, two invasive species, occur in Madagascar. Ae. (Stg.) pia (Le Goff \& Robert), absent from Madagascar (this study, [5]), was ranked by WRBU among the mosquito species found on the island [244].

\section{- Aedes (Stegomyia) aegypti (Linnaeus, 1762)}

Bigot, 1859 [12]

In Madagascar, larval habitats are tree holes [103], peridomestic, tires, cans, metal drums, vehicle carcasses, small receptacles, and tree holes filled with rainwater and plant matter [182]. Occurs in all Malagasy biogeographic domains, with a high density in the western and southern domains where a large number of specimens were captured using human landing [85, 177]. In Madagascar, found naturally infected with BABV, MMP 158 virus, and WNV [85]. Known worldwide as vector of YFV [204], DENV [38], ZIKV [153], CHIKV [212], and at least 16 viruses [1]. Field vertical transmission of YFV [92] and DENV was already described for this species. Extrinsic development of ONNV was also described [231].

\section{- Aedes (Stegomyia) albopictus (Skuse, 1894)}

Ventrillon, 1905

In Madagascar, larval habitats are natural and artificial containers [small receptacles, tires, tree holes (coffee), cut 
bamboo, drums, cans] and leaf axils of Pandanus [182]. Occurs in all Malagasy biogeographic domains [85]. Currently expanding its geographic distribution in Madagascar, to the detriment of Aedes aegypti [177]. Found naturally infected with BABV in Madagascar [85]. Known worldwide as potential vector of SINBV [60], Cache Valley virus (CVV) [166], La Crosse virus (LACV) [94], Potosi virus (POTV) [6], CHIKV, DENV [55], and Banna virus (BAV) [148]. Involved in transmission of WNV in North America [8].

\subsubsection{Subgenus Zavortinkius Reinert, 1999}

This subgenus includes 11 species [241]. Four species occur in Madagascar with three endemic species. Before creating the subgenus Zavortinkius, the Malagasy species were considered to belong to the subgenus Finlaya.

\section{- Aedes (Zavortinkius) brygooi Brunhes, 1971}

Brunhes, 1971 [22]

Endemic. Eggs undescribed. Larval habitats are tree holes full of plant organic matter [182]. Occurs essentially in warm regions characterized by a long dry season, and in Nosy Komba [90] and in all Malagasy biogeographic domains, with the exception of the eastern domain [85, 182]. Not involved in disease transmission.

\section{- Aedes (Zavortinkius) interruptus Reinert, 1999}

Reinert, 1999 [187]

Endemic. Only the adult stages (male and female) were described [187]. Larval habitats are water-filled trees [207]. Adult biology unknown. Occurs in the eastern [187] and central [210] biogeographic domains. Not involved in disease transmission.

\section{- Aedes (Zavortinkius) monetus Edwards, 1935}

\section{Edwards, 1935 [79]}

Eggs and pupal stages undescribed. First reported in Madagascar and was also collected on the islands of Comoros, Mayotte, and Moheli [24]. Larval habitats are tree holes filled with rainwater and plant organic matter [182]. Occurs in all Malagasy biogeographic domains (except the central domain) $[85,182]$. Not involved in disease transmission.

\section{- Aedes (Zavortinkius) phillipi van Someren, 1949 van Someren, 1949 [229]}

Endemic. Eggs undescribed. Larval habitats are sectioned trunks of Ravenala sp. [22], tree holes [207], rarely leaf axils of Pandanus [182], bamboo ovitraps, and leaf axils of agave [85]. Essentially present in the warmer and humid eastern coast of Madagascar, also occurs in Nosy Komba, in the Sambirano area, western and northern [85] and the central [210] domains. Not involved in disease transmission.

\subsection{Genus Coquillettidia Dyar, 1905 [71]}

This genus includes 57 species in the world [117]. These species represent three subgenera: Coquillettidia, Rhynchotaenia, and Austromansonia. In Madagascar, only the subgenus
Coquillettidia is present and it is represented by three species. Two of them are endemic to Madagascar. Larval and pupal stages of Coquillettidia species derive their oxygen by puncture of the aerenchyma of aquatic plants. The report of Coquillettidia (Coquillettidia) aurites (Theobald) as present in Madagascar in Arim dataset [5] is doubtful as information on collection areas is not available. De facto this information was treated as an error.

\section{- Coquillettidia (Coquillettidia) grandidieri (Blanchard, 1905) \\ Ventrillon, 1904 [232]}

Endemic. Eggs and pupal stages undescribed. Larval habitats are flushing holes containing clear water and floating aquatic plants [140]. Occurs in the western, eastern, and central biogeographic domains [85, 210]. Anthropophilic [85] and zoophilic species (feeds on domestic ruminants) [210]. RVFV was found in a mixed batch of mosquito species, which included Cq. grandidieri, collected in Périnet [85].

\section{- Coquillettidia (Coquillettidia) metallica (Theobald, 1901) [214] \\ Doucet, 1951 [67]}

Eggs undescribed. Larval habitats are unknown. In Madagascar, occurs in the western, eastern, and central domains and frequently caught in human landing catches [85]. In Madagascar, not involved in transmission of vector-borne disease. In Africa, involved in transmission of WNV [127], BABV, MIDV [1], and avian Plasmodium parasite [171].

\section{- Coquillettidia (Coquillettidia) rochei (Doucet, 1951) [67]}

Doucet, 1951 [67]

Endemic. Only adult males and females were described [67]. Larval habitats are unknown. Occurs at low altitude, in the western and eastern domains [67, 85, 140], with the exception of the forest corridor Anjozorobe-Angavo where this species was collected at altitudes below $1000 \mathrm{~m}$ asl [210]. Anthropophilic [85] but not involved in transmission of vector-borne diseases.

\subsection{Genus Culex Linnaeus, 1758}

The genus Culex includes 26 subgenera and 769 species in the world [119]. In total, 45 species from 6 subgenera were described in Madagascar. They include two Culex salisburiensis subspecies (Culex salisburiensis salisburiensis and Culex salisburiensis coursi). In Madagascar, like in many regions of the world, the systematics of Culex have to be revisited. The majority of these species belong to the subgenus Culex. Ten species are endemic to Madagascar. Culex salisburiensis coursi was described only from a single specimen.

\subsubsection{Subgenus Culex Linnaeus, 1758}

This subgenus includes 198 species in the world. Twentyseven species were recorded in Madagascar. Among them, Culex scottii Theobald and $C x$. vansomereni Edwards were 
inventoried in this study and in the Arim dataset [5]. Three species are endemic to Madagascar and two other species occur on several Indian Ocean islands. The report of $C x$. sinaiticus Kirkpatrick in the Arim dataset [5] and Cx. thalassius Theobald in WRBU [244] as present in Madagascar is doubtful as information on collection areas is not available. De facto this information was treated as an error.

\section{- Culex (Culex) antennatus (Becker, 1903) [11]}

Edwards, 1920 (as Cx. laurenti) [75]

This species belongs to Subgroup Decens in the Group Pipiens [115]. Larval stages are morphologically close to those of $C x$. decens Theobald [124] and Cx. quasiguiarti Theobald [230]. Often confused with $C x$. univittatus Theobald and $C x$. trifoliatus Edwards [230], which is absent in Madagascar. In Madagascar, larval habitats are the hoof prints, canals, marshes, ditches, water reservoirs [63] and rice fields [67, 191]. Occurs in the Sambirano area (Nosy Be, Nosy Komba) [90], and all Malagasy biogeographic domains, except the northern domain $[85,181]$. Zoophilic species and prefers to feed on cattle [210]. Frequently caught in the human landing catches in the central highlands [85] and may be attracted to poultry [210]. Involved in the transmission of Wuchereria bancrofti [20], RVFV [181, 210], WNV, and PERV [85]. BABV was isolated from a mixed batch of mosquito species, which included CX. antennatus, collected in Périnet [85]. In Africa, zoophilic species (especially livestock) and occasionally feeds on humans [114]. Involved in transmission of NGAV [101], BABV, BAGV, WSLV, WNV [1], and Setaria sp. [16]. Sporozoites of avian Plasmodium parasite were reported in Cx. antennatus [199].

\section{- Culex (Culex) argenteopunctatus (Ventrillon, 1905)} [233]

Ventrillon, 1905 [233]

Endemic. Eggs undescribed. Larval habitats are wetlands [18], rice fields [67], grassy holes [30], puddles, and ponds [85]. Occurs in the central $[85,210]$ and eastern domains [67]. Culex argenteopunctatus exhibits strong positive phototropism using light traps, even within urban areas [85]. Not involved in the transmission of diseases.

\section{- Culex (Culex) carleti Brunhes \& Ravaonjanahary, 1971 [29]}

Brunhes and Ravaonjanahary, 1971 [29]

Endemic species to Madagascar and to the Comoros archipelago [29]. Eggs undescribed. Larval stages are morphologically close to $C x$. perfidiosus Edwards and $C x$. mirificus Edwards [29], which is absent in Madagascar. In Madagascar, larval habitats are cut bamboo [29]. Occurs in the Sambirano area (Nosy Be, Nosy Komba) [90] and in the eastern domain [85]. Captured during daytime catches in human landing catches [85]. Not involved in transmission of vector-borne diseases.

\section{- Culex (Culex) comorensis Brunhes, 1977 [24]}

Brunhes, 1977 [24]

Endemic species to Madagascar and to the Comoros archipelago [24]. Eggs undescribed. Larval habitats are ovitraps, tree holes, puddles, ponds, and tire tracks [85]. Described in the Comoros archipelago, and collected by Brunhes in the Ankaratra Massif (1700 m asl) [24] and in the AndasibeMantadia forest (or forest Périnet), in the eastern domain [85]. Rare in Madagascar and not involved in the transmission of vector-borne diseases.

\section{- Culex (Culex) decens Theobald, 1901 [215]}

Edwards, 1941 [80]

Eggs undescribed. Belongs to Decens Group, which is represented by $C x$. decens, $C x$. quasiguiarti, $C x$. guiarti Blanchard, Cx. scottii, and Cx. weschei Edwards in Madagascar. The adult stages of these five species are morphologically close, and they are distinguishable by male morphology [85]. Culex decens and Cx. invidiosus Theobald are morphologically close, and few morphological differences were proposed in the larval [115] and adult stages [80]. In Madagascar, the breeding sites of $C x$. decens include tree holes [103], ponds, rice fields, and swamps [67]. This species also grows in artificial ovitraps and bamboo [85]. This species is present in all Malagasy biogeographic domains [85]. Culex decens is abundant in the central domain $[85,210]$ and exhibited anthropophilic behavior in the village of Anjiro during the day [85]. This species exhibits positive phototropism using light traps [85] and may be attracted to livestock and poultry [210]. WNV and BABV were isolated from specimens caught in the Tsiroanomandidy area [85]. In Africa, this species was involved in the transmission of SINV, Usutu virus (USUV) [47], Moussa virus (MOUV) [175], BAGV, WNV, M'Poko virus (MPOV), Mossuril (MOSV), and Kamese virus (KAMV) [1].

\section{- Culex (Culex) demeilloni Doucet, 1950 [65] \\ Doucet, 1950 [65]}

Endemic. Only larval stages were described [65]. The type was collected in a rice field in the Ambositra region [65]. This larval specimen has never been found in Madagascar since that time. Morphologically close to Culex guiarti by the presence of nine posterolateral combs of segment VIII and well visible teeth of the mentum [65].

\section{- Culex (Culex) duttoni Theobald, 1901 [215]}

Edwards, 1941 [80]

Eggs undescribed. It is the only species of the Group Duttoni [115]. Its larval stages probably indistinguishable from those of Culex watti Edwards [124]. In Madagascar, larval habitats are puddles [103]. Occurs in the Sambirano area (Nosy Be) [90] and in a few localities of the central biogeographic domain [85]. Involved in the transmission of the Flavivirus in Africa (Yaoundé virus [YAOV], Ar 11266 B virus, UGSV) [1].

\section{- Culex (Culex) grahamii Theobald, 1910 [220] Doucet, 1950 [65]}

Eggs undescribed. Collected in Madagascar one time by Doucet in the Ambatolampy region [65]. The presence of this African species is questioned in Madagascar. This species can be confused with $C x$. striatipes Edwards. 


\section{- Culex (Culex) guiarti Blanchard, 1905}

Doucet, 1950 [65]

Eggs undescribed. In Madagascar, larval habitats are canals, ponds, rice fields, stagnant water ponds [67], and grassy holes [30]. Rare species and occurs only in the eastern domain $[30,67,85]$. Captured in human landing catches during nighttime catches [85]. In Madagascar, not involved in transmission of vector-borne diseases. In Africa, involved in transmission of at least 12 viruses [1], for instance BAGV [45] and WNV [127], and Avian Plasmodium parasite [171].

\section{- Culex (Culex) neavei Theobald, 1906 [218]}

Fontenille \& Jupp, 1989 [88]

Eggs undescribed. Morphologically close to $C x$. univittatus, also present in Madagascar. In Madagascar, larval habitats are still unknown. Presence reported only from the Tsiroanomandidy region [88]. Not involved in disease transmission. In Africa, may be attracted to domestic ruminants, poultry, and humans [10]. Involved in transmission of at least 16 viruses (Alphavirus, Flavivirus, Bunyaviruses, Orbivirus) [1] and avian Plasmodium parasite in Cameroon [171]. Seems to have a lower vectorial capacity than $C x$. univittatus for the transmission of WNV [88].

\section{- Culex (Culex) perfidiosus Edwards, 1914}

\section{Doucet, 1949 [64]}

Egg and pupal stages undescribed. Larval stages might be confused with those of $C x$. carleti, which were described in 1971 [29]. Larval habitats are in the rice fields, water holes, swamps, puddles, lakes, and flooded grasslands [63, 67]. In Madagascar, occurs in the eastern domain [63, 67].

\section{- Culex (Culex) pipiens Linnaeus, 1758}

Edwards, 1920 [75]

Eggs appear to be very similar in surface morphology to those of Culex quinquefasciatus Say [2]. In Madagascar, larval habitats are irrigation drains, canals, tires, and water tanks [207, 227]. In the central domain, occurs essentially in urban and suburban areas [227], also abundant in the Anorana rainforest, in the Anjozorobe district, in Antananarivo province [210]. A few specimens were recently collected in the western domain $[15,170]$. Zoophilic species, prefers to feed on cattle and poultry. Not involved in disease transmission in Madagascar. In Africa, involved in transmission of RVFV [123], SINV [242], and avian Plasmodium parasite (presence of sporozoites) [199]. In North America, vector of WNV [8].

\section{- Culex (Culex) quasiguiarti Theobald, 1910 [220]}

\section{Edwards, 1941 [80]}

Eggs undescribed. Morphologically close to Culex decens and $C x$. invidiosus, and distinguishable by male genitalia morphology. In Madagascar, larval habitats are unknown. Occurs near Lake Alaotra (in the eastern domain) [80], in the Tsiroanomandidy region (central domain) [85], in the Ihosy and Ampandrandava regions (at the boundary between the southern and western domains) [80]. Not involved in the transmission of diseases.

\section{- Culex (Culex) quinquefasciatus Say, 1823}

Edwards, 1920 [80]

Eggs appear to be very similar in surface morphology to those of Culex tritaeniorhynchus Giles [205] and Culex pipiens [2]. Belongs to the subgroup pipiens of the Group Pipiens [115] and has about 40 synonyms. In Madagascar, larval habitats are sewage, tires, plastic containers, and metal drums (Tantely, unpublished data). Occurs in all geographic domains with a preference for urban environments [85]. Anthropophilic species [85] and may be attracted to domestic ruminants (Luciano Tantely, unpublished observation). Involved in the transmission of Wuchereria bancrofti [20], WNV, BABV, and endemic PERV [85]. In the world, has a variable host preference from high degree of mammalophily and anthropophily to a high degree of ornithophily [206]. Involved in transmission of RVFV [198], CHIKV, WNV, and MgV [1]. Involved in transmission of avian Plasmodium parasite (presence of sporozoites) in India and the United States of America [199].

\section{- Culex (Culex) scottii Theobald, 1912 [221]}

Fontenille \& Mathiot, 1984 [86]

Eggs, larval and pupal stages undescribed. Morphologically close to Culex pipiens Linnaeus, Cx. musarum Edwards, and $C x$. hancocki Edward. Culex musarum and $C x$. hancocki absent in Madagascar. Supposed to be endemic to the Seychelles [156], but occurs in Madagascar in the central (Mahasolo region) and in the eastern (Taolagnaro, Soanierana Ivongo, and Périnet) domains [85]. In Madagascar, anthropophilic and diurnal species [85] in the eastern and central domains [85]. WNV was isolated from specimens morphologically close to $C x$. scottii, captured from an outdoor resting area near a cattle park in Mahazoarivo village (Mahasolo, Antananarivo province) [85].

\section{- Culex (Culex) simpsoni Theobald, 1905 [217]}

\section{Doucet, 1950 [65]}

Eggs undescribed. Belongs to the subgroup Simpsoni of Group Pipiens [115]. In Madagascar, larval habitats are ponds [66], rock holes [103], fishponds, and tire tracks [85]. Occurs in the Sambirano area (in Nosy Be) [90] and in the eastern domain [66]. Rarely captured in human landing catches [85]. RVFV was found in a mixed batch of Culex mosquito species, including Culex simpsoni, collected in Périnet [85].

\section{- Culex (Culex) sitiens Wiedemann, 1828}

Edwards, 1941 [80]

Eggs undescribed. Belongs to the Group Sitiens [115]. In Madagascar, larval habitats are unknown, occurs in the Sambirano area (Nosy Be, Nosy Komba) [90], and in the western and central domains [85]. Not involved in disease transmission in Madagascar. In Africa, involved in transmission of MOSV in Mozambique [134], Murray Valley Encephalitis virus (MVEV), Japanese Encephalitis virus (JEV), Sepik virus (SEPV), and SINV in New Guinea [128]. In Malaysia, involved in the transmission of avian Plasmodium parasite (presence of sporozoites) [199]. 


\section{- Culex (Culex) striatipes Edwards, 1941 [80]}

Brunhes \& Ravaonjanahary, 1973 [30]

Egg and pupal stages undescribed. Larval stages are morphologically close to those of Culex grahamii Theobald [124]. In Madagascar, larval habitats are grassy swamps [30] and rice fields [191]. Occurs in the eastern and central domains, over $900 \mathrm{~m}$ asl [30]. Adult biology unknown and not involved in the transmission of diseases.

\section{- Culex (Culex) theileri Theobald, 1903 [216]}

Doucet, 1951 [67]

Eggs undescribed. Belongs to Subgroup Theileri of Group Pipiens [115]. In Madagascar, presence reported with single female collected by Doucet in Vangaindrano area, on the eastern coast [67]. Presence is questioned in Madagascar.

\section{- Culex (Culex) tritaeniorhynchus Giles, 1901 [96]}

Doucet, 1950 [65]

Eggs appear to be very similar in surface morphology to those of Culex quinquefasciatus [205]. Belongs to the Group Vishnui [115]. In Madagascar, larval habitats are in rice fields [67]. Occurs in all biogeographic domains of Madagascar. Frequently captured in human landing catches in the Morondava and Mahajanga regions [85]. Considered as a sylvatic vector of WNV [85]. $\mathrm{MgV}$ was isolated from this species [85]. In the world, major vector of JEV, SINV [242], NGAV and BABV [101], RVFV [129], Sagiyama virus (SAGV), Oya virus (OYAV), AKAV and Getah virus (GETV) [34], Yunnan orbivirus (YUOV) [7], and BANV [148]. In Japan, involved in transmission of avian Plasmodium parasite (presence of oocyst) [199].

\section{- Culex (Culex) perfuscus Edwards, 1914}

Grjebine, 1955 [5]

Eggs and pupal stages undescribed. No literature has reported its presence in Madagascar. However, this species occurs in Nosy Be, in the Sambirano area, as shown on the labels of specimens stored at the IRD of Montpellier [5]. Biology unknown. Not involved in transmission of diseases on the island. In Africa, involved in transmission of at least 19 viruses [1].

\section{- Culex (Culex) trifilatus Edwards, 1914}

Brunhes, 1971 [5]

Eggs, larval and pupal stages undescribed. No literature has reported its presence in Madagascar. However, this species occurs in Namakia, in the western domain, as shown on the labels of specimens stored at the IRD of Montpellier [5]. Biology unknown. Not involved in disease transmission.

\section{- Culex (Culex) univittatus Theobald, 1901 [215]} Ventrillon, 1905 [233]

Eggs undescribed. Belongs to the Group Pipiens [115]. Larval stages might be confused with those of $C x$. quasiguiarti Theobald [230], Cx. decens, and Cx. antennatus. Adult stages morphologically close to $C x$. neavei, also present in Madagascar. In Madagascar, larval habitats are rice fields and marshes [67]. Occurs in all Malagasy biogeographic domains (except the northern domain). Frequently found and abundant in the central highlands [85], exhibits positive phototropism [85]. In the central highlands, collected in net-traps baited with domestic ruminants and poultry [210]. In Madagascar, $\mathrm{MgV}$ was isolated from this species [85]. This species was found naturally infected with BABV in a mixed batch of mosquito species collected in Périnet [85]. In Africa, anthropophilic species and can also feed on cattle [114]. Involved in transmission of WNV [163], BABV [101], BAGV [165], RVFV [198], Wuchereria bancrofti [16], and avian Plasmodium parasite (presence of sporozoites) [199].

\section{- Culex (Culex) ventrilloni Edwards, 1920 [75]}

Edwards, 1920 [75]

Endemic. Eggs, larval and pupal stages undescribed. Morphologically close to $C x$. simpsoni and male genitalia of these two species are morphologically identical [80]. Presence only reported in Antananarivo city [85]. Further studies are needed to guarantee the status of this endemic species. Adult biology unknown. Not involved in disease transmission.

\section{- Culex (Culex) watti Edwards, 1920 [74]}

Ravaonjanahary, 1979 [183]

Eggs undescribed. Larval stages morphologically close to those of Culex duttoni [124]. The larva of Culex watti is characterized by the presence of two subdorsal siphonal bristles which are absent in Culex duttoni [183]. In Madagascar, typical larval habitats are shady rock holes [183]. Occurs in the Sambirano area (Nosy Be, Nosy Komba) [90] and occasionally reported in the eastern domain [85]. Adult biology unknown. Not involved in disease transmission.

\section{- Culex (Culex) vansomereni Edwards, 1926 [77]}

Clerc \& Coulanges, 1979 [40]

Eggs undescribed. In Madagascar, larval habitats are unknown. Presence only reported in the Andasibe-Mantadia forest (or Périnet forest) in the eastern domain [40, 85]. Rare species. Adult biology unknown. BABV and RVFV were isolated from a mixed batch of mosquito species, including this species, collected in Périnet forest [85]. In Africa, ornithophilic species and competent vector of WNV under laboratory conditions [150]. Potential vector of RVFV [147].

\section{- Culex (Culex) weschei Edwards, 1935 [79]}

Brunhes \& Ravaonjanahary, 1973 [30]

Eggs and pupal stages undescribed. In Madagascar, larval habitats are grassy holes [30]. Occurs in the eastern and central domains $[30,85]$ and caught in human landing catches during daytime catches [85]. Not involved in disease transmission. In Africa, involved in transmission of WNV, MOSV, SINV [45], CHIKV, BABV, and WSLV. $\mathrm{MgV}$ was isolated from this species [1].

\subsubsection{Subgenus Culiciomyia Theobald, 1907 [219]}

This subgenus includes 55 species in the world. Six species occur in Madagascar, two of them are endemic species to the island. The report of CX. semibrunneus Edwards as present in 
Madagascar in the Arim dataset [5] is doubtful as information on collection areas is not available. De facto this information was treated as an error.

\section{- Culex (Culiciomyia) cinerellus Edwards, 1922 [76]}

Grjebine, 1953 [103]

Eggs undescribed. Larval stages are morphologically close to those of $C x$. subaequalis Edwards [124]. In Madagascar, larval habitats are tree holes [103] and many phytotelmata [27]. Occurs in the Sambirano area (Nosy Be, Nosy Komba) [90] and in the eastern domain. Caught in human landing catches during night-time catches [85]. Not involved in disease transmission.

\section{- Culex (Culiciomyia) cinereus Theobald, 1901}

Grjebine, 1953 [103]

Eggs undescribed. In Madagascar, larval habitats are tree holes [103]. Rare species and occurs in the western domain [103] and Sambirano area [85]. Adult biology unknown. In Africa, involved in transmission of at least 16 viruses [1].

\section{- Culex (Culiciomyia) milloti Doucet, 1949}

Doucet, 1949 [64]

Endemic. Only the larval stages were described [64]. Known only from a single specimen captured in the Tsimbazaza Park in Antananarivo [64]. Its larvae have similarities with those of Culex nebulosus. Larval habitats are water tables containing dissolved organic matter [64].

\section{- Culex (Culiciomyia) nebulosus Theobald, 1901} Edwards, 1941

Eggs undescribed. In Madagascar, larval habitats are tree holes [103], bamboo trunks [85], and many phytotelmata [27]. Occurs in the Sambirano area (Nosy Be, Nosy Komba) [90], in the western, eastern, and central domains [85]. Captured in human landing catches [85], but not involved in disease transmission. In Africa, involved in transmission of Ntaya virus (NTAV) [17], BABV, MIDV, BAGV, YAOV, MPOV, and Tai virus (TAIV) [1].

\section{- Culex (Culiciomyia) pandani Brunhes, 1969 [21]}

Brunhes, 1969 [21]

Endemic. Eggs undescribed. Larval habitats are cut trunks of Ravenala [29], tree holes, leaf axils of Pandanus [182] and agave [85], and many phytotelmata [27]. Rare species and occurs throughout the eastern cliffs of Madagascar [21, 85]. Captured in human landing catches during daytime catches [85]. Not involved in disease transmission.

\section{- Culex (Culiciomyia) subaequalis Edwards, 1941} Brunhes, 1967 [5]

Eggs, pupal stages, and adult female undescribed. No literature has reported the presence of $C x$. subaequalis in Madagascar. Occurs on the island, as shown on the labels of specimens stored at the IRD of Montpellier [5]. The locality type was not well specified. Biology unknown. Not involved in disease transmission.

\subsubsection{Subgenus Kitzmilleria Danilov, 1989}

This subgenus includes only one species in the world: $C X$. (Kit.) moucheti.

\section{- Culex (Kitzmilleria) moucheti Evans, 1923}

Coulanges et al., 1977 [48]

Eggs undescribed. Formerly classified in the subgenus Culex. In Madagascar, rare species and reported in the Andasibe-Mantadia forest (forested area near Périnet) in the eastern area [85]. Biology unknown. Not involved in disease transmission. In Africa, involved in transmission of NTAV [17].

\subsubsection{Subgenus Oculeomyia Theobald, 1907}

This subgenus, rehabilitated by Tanaka in 2004, is represented by 19 species in the world. Five species are present in Madagascar and one species is endemic to the island. This study includes $C x$. aurantapex Edwards that was not ranked among the mosquito species found on the island in WRBU [244]. The morphological diversity and the worldwide distribution of the species of subgenus Oculeomyia suggest that it is an old group [203]. Similar characters are observable in the larval stages for the majority of these species [124].

\section{- Culex (Oculeomyia) annulioris Theobald, 1901}

Clerc \& Coulanges, 1980 [41]

Eggs undescribed. In Madagascar, larval habitats are unknown. Occurs in the eastern forest [41], central [210], western [15], and southern domains [170]. RVFV was isolated in a mixed batch of mosquito species, including $C x$. annulioris, collected in Périnet forest [41]. In Africa, zoophilic species [114] and involved in transmission of SINV [237] and MIDV [1], and avian Plasmodium parasite (in Cameroon) [171].

\section{- Culex (Oculeomyia) aurantapex Edwards, 1914} Brunhes, 1975

Eggs, pupal stages, and adult male undescribed. In Madagascar, larval habitats are unknown. Occurs only in the eastern area. Specimens collected at Périnet should be re-examined as all species close to Group Annulioris [85]. Captured in human landing catches during daytime catches [85], but not involved in disease transmission.

\section{- Culex (Oculeomyia) bitaeniorhynchus Giles, 1901}

Doucet, 1950 [65]

Eggs undescribed. In Madagascar, larval habitats are flooded grasslands [63], puddles [65], cattle hoof prints, swamps, rice fields, and ponds $[67,191]$. Occurs in the western, eastern, central [85] and southern (in the Tsihombe region) biogeographic domains [65]. Captured in human landing catches [85], but not involved in disease transmission. In Africa, involved in transmission of SINV [196], SAGV, GETV [34], and RVFV [198]. In Japan, involved in transmission of avian Plasmodium parasite (with sporozoites) [199].

\section{- Culex (Oculeomyia) giganteus Ventrillon, 1906 Ventrillon, 1906}


Endemic. Eggs undescribed. Classified in the Bitaeniorhynchus Series of Group Lasioconops [78]. Currently, Harbach ranks this species in the subgenus Oculeomyia [119], contrary to what is indicated in Arim [5]. In Madagascar, larval habitats are grassy swamps, rice fields, and slow-flowing streams [18]. Occurs in the central domain $[85,210]$ and abundant on the eastern margins, in the medium altitude forest of Ranomafana (Fianarantsoa) and Périnet forest (or Andasibe-Mantadia forest) [85]. Recently observed in the western and southern domains [170]. May be attracted to domestic ruminants, poultry, and humans [210], but not involved in disease transmission.

\section{- Culex (Oculeomyia) poicilipes (Theobald, 1903)}

Ventrillon, 1905 [233]

Egg and pupal stages undescribed. Morphologically atypical species, and classified in the subgenus Oculeomyia [244], contrary to what is indicated in Arim [5]. In Madagascar, larval habitats are ponds and rice fields $[67,103]$. Occurs particularly in the central and eastern domain and collected in abundance around lake Soamalipo, in the Antsalova region of the western domain [15]. May be attracted to humans and poultry bait [85] (Luciano Tantely, unpublished observation). Not involved in disease transmission. In Africa, zoophilic species and feeds on livestock, birds, and humans [114]. Involved in transmission of NGAV [101], WNV, BAGV [222], RVFV, SANV [58], Setaria sp. [16], and avian Plasmodium parasite (in Cameroon) [171].

\subsubsection{Subgenus Eumelanomyia Theobald, 1909}

This subgenus includes 77 species in the world [119]. Among which eight species are present in Madagascar with two endemic species to the island, and $C x$. sunyaniensis Edwards that was not ranked by WRBU among the mosquito species of the island [244].

\section{- Culex (Eumelanomyia) brenguesi Brunhes \&} Ravaonjanahary, 1973 [30]

Brunhes \& Ravaonjanahary, 1973 [30]

Endemic. Eggs undescribed. Belongs to Group Rubinotusrima [30]. Larval stages are morphologically close to those of $C x$. sunyaniensis. Larval habitats are grassy holes and swamps [30]. Rare species and occurs in the eastern domain [30]. Adult biology unknown. Not involved in disease transmission.

\section{- Culex (Eumelanomyia) chauveti Brunhes \& Rambelo, 1968}

Brunhes \& Rambelo, 1968 [28]

Endemic to Madagascar and to the Comoros archipelago (Mohéli) [28]. Eggs undescribed. Larval habitats are temporary pools and small grassy pools under forest cover [28, 143]. Occurs on the eastern slopes of the central highlands and in the eastern domain [28, 85]. Captured in human landing catches during daytime catches [85]. Not involved in disease transmission.

\section{- Culex (Eumelanomyia) horridus Edwards, 1922}

Grjebine, 1953 [103]

Eggs undescribed. Belongs to the Group Protomelanoconion [202]. Includes two subspecies: the only subspecies
Cx. horridus is present in Madagascar. Larval habitats are tree holes [103]. Occurs in the western [103] and central domains [85]. Adult biology unknown. Not involved in disease transmission.

\section{- Culex (Eumelanomyia) insignis (Carter, 1911)} Grjebine, 1955 [5]

Eggs undescribed. No literature has reported its presence in Madagascar. However, this species occurs in Nosy Be, in the Sambirano area, as shown on the labels of specimens stored at the IRD of Montpellier [5]. Biology unknown. Not involved in disease transmission.

\section{- Culex (Eumelanomyia) kingianus Edwards, 1922}

Doucet, 1950 [65]

Eggs undescribed. In Madagascar, larval habitats are tree holes [85], and phytotelmata [27], fresh water marshes (in Mahajanga city) [112]. Occurs in the western [103] and eastern domains [85]. Adult biology unknown. Not involved in disease transmission.

\section{- Culex (Eumelanomyia) rubinotus Theobald, 1906}

Fontenille \& Mathiot, 1984 [89]

Eggs undescribed. In Madagascar, larval habitats are tree holes [85] and many phytotelmata [27]. Occurs in the Sambirano area (Nosy Be) [90] and in the eastern domain [85]. Not involved in disease transmission. In Africa, involved in transmission of RVFV [147], UGSV, Germiston virus (GERV) [1], Banzi (BANV), and Witwatersrand (WITV) virus [162].

\section{- Culex (Eumelanomyia) sunyaniensis Edwards, 1941}

Doucet, 1950 [65]

Eggs undescribed. In Madagascar, larval habitats are slow streams of Périnet forest and in leaf axils of Pandanus located in the Vangaindrano region of the eastern domain [66]. Its presence must be confirmed by observing male genitalia morphology. Adult biology unknown. Rare species, not involved in disease transmission.

\section{- Culex (Eumelanomyia) wigglesworthi Edwards, 1941} Grjebine, 1952 [5]

Egg and pupal stages undescribed. No literature has reported its presence in Madagascar. However, this species occurs in Manakara, eastern domain, as shown on the labels of specimens stored at the IRD of Montpellier [5]. Biology unknown. Not involved in disease transmission.

\subsubsection{Subgenus Maillotia Theobald, 1907}

This subgenus includes nine species in the world [119]. Two species of this subgenus are reported in Madagascar. The report of $C x$. avianus de Meillon as present in Madagascar in the WRBU dataset [244] is doubtful as information on collection areas is not available. De facto this information was treated as an error.

- Culex (Maillotia) salisburiensis Theobald, 1901

Doucet, 1949 [63] 
In Madagascar, presence reported of two Culex salisburiensis subspecies (Culex salisburiensis salisburiensis and Culex salisburiensis coursi). The subspecies Culex salisburiensis coursi, endemic [63], described only from a single specimen and known only at larval stages collected from rice fields in the eastern domain. Sympatric with Culex salisburiensis salisburiensis in the Lake Alaotra region on the eastern slope of the central highlands [63]. For Culex salisburiensis salisburiensis, pupal stage and eggs undescribed. Adult biology unknown. Not involved in the transmission of diseases.

\section{- Culex (Maillotia) seyrigi Edwards, 1941 [80]}

Edwards, 1941 [80]

Endemic. Eggs undescribed. In Madagascar, larval habitats are swamps [18], rock holes and grassy ditches [19]. Occurs in the central domain [19]. Adult biology unknown. Not involved in disease transmission.

\subsection{Genus Eretmapodites Theobald, 1901}

The genus Eretmapodites includes 48 species that occur only in Afrotropical region [117, 119]. Four species were reported in Madagascar.

\section{- Eretmapodites oedipodeios Graham, 1909}

Doucet, 1950 [65]

Eggs, larval and pupal stages undescribed. Presence reported in Madagascar by Doucet, only in 1950 from specimens caught by Paulian in Taolagnaro [65]. In Africa, involved in transmission of Eret 147 virus in Cameroon [1].

\section{- Eretmapodites plioleucus Edwards, 1941}

Doucet, 1950 [65]

Eggs, larval and pupal stages undescribed. Includes two subspecies: Er. plioleucus brevis and Er. plioleucus plioleucus. Morphologically close to Er. leucopous Graham which is absent from Madagascar. In Madagascar, presence reported only in 1950 by Doucet, from specimens caught by Paulian on Europa island and in the Lokobe region of the Sambirano area [65]. Its presence on the Indian Ocean islands is questioned. Not involved in disease transmission.

\section{- Eretmapodites quinquevittatus Theobald, 1901 [214]}

Ventrillon, 1905 [233]

In Madagascar, larval habitats are stagnant water [65] and many phytotelmata [27]. Occurs in all Malagasy biogeographic domains [85]. Rare species in the central domain [85]. Anthropophilic and diurnal species under forest area [85]. $\mathrm{MgV}$ was isolated from Er. quinquevittatus [90]. In Africa, involved in transmission of RVFV [174] and viruses belonging to the genera Flavivirus and Bunyaviruses [1].

\section{- Eretmapodites subsimplicipes Edwards, 1914}

Doucet, 1951 [66]

Eggs undescribed. In Madagascar, presence reported only in 1951 by Doucet in Périnet forest in the eastern domain [66]. Adult and larval biology unknown. Rare species and not involved in disease transmission. In Comoros archipelago, anthropophilic and nocturnal species [24]. In Kenya, involved in transmission of Okola virus (OKOV) [1].

\subsection{Genus Ficalbia Theobald, 1903}

The genus Ficalbia belongs to the tribe Ficalbiini with the genus Mimomyia. The genus Ficalbia is represented by only eight species in the world [119]. Four species occur in the Afrotropical region. In Madagascar, this genus is represented by two species. Among them, Fi. circumtestacea was not reported as present on the island by WRBU [244]. Some specimens collected in other bioclimatic domains by Fontenille [85] could not be identified with confidence. This observation suggests that this genus is probably insufficiently studied in Madagascar.

\section{- Ficalbia uniformis (Theobald, 1904)}

Doucet, 1949 [63]

Larval habitats are flooded meadows, marshes, canals, and deep clear water containing abundant aquatic vegetation [63]. Occurs in the eastern and central domains [63]. Adult biology unknown. Not involved in disease transmission.

\section{- Ficalbia circumtestacea (Theobald, 1908)}

Grjebine, 1986 [110]

Eggs undescribed. In Madagascar, reported at the larval stage, in the eastern domain, in the Andasibe-Mantadia and Manakara regions [110] and adult stage in Antsalova district of the western domain [15]. Adult biology unknown. Not involved in disease transmission.

\subsection{Genus Hodgesia Theobald, 1903}

The Hodgesia is represented by 11 species in the world [119]. Four species occur in Afrotropical region, mainly in central Africa. Adult females of African specimens are indistinguishable [158]. In Madagascar, presence was reported by Fontenille [85] who captured seven adults in human landing catches during daytime catches in April 1984 in the Mandena forest (Taolagnaro) [85]. The Malagasy specimens are still unidentified to date. This is probably the reason why Arim and WRBU did not rank this genus among the mosquito genera found in Madagascar [5, 244]. Two females are currently stored in the laboratory of vector taxonomy of IRD Montpellier. Two other female specimens were caught by Didier Fontenille, in human landing catches, in May 1983, in the Antetezana forest, along the eastern coast between Toamasina and Foulpointe (Gilbert Le Goff, unpublished observation). Capture efforts for larval stages in swamp areas of the eastern coast could facilitate specimen collection and species identification. Hodgesia is poorly known, and rarely feeds on humans and is not known to be involved in medical or veterinary pathogen transmission.

\subsection{Genus Lutzia Theobald, 1903}

The genus Lutzia was formerly classified in the genus Culex and it was subdivided into three subgenera represented 
by eight species in the world [119]. Only one species belonging to the subgenus Metalutzia is present in the Afrotropical region and Madagascar.

\subsubsection{Subgenus Metalutzia Tanaka, 2003}

This subgenus includes five species; one species occurs in Madagascar: Lutzia tigripes.

\section{- Lutzia (Metalutzia) tigripes de Grandpre \& de Charmoy, 1901}

Edwards, 1920 [75]

Eggs undescribed. Larval stages are predators of mosquitoassociated species and usually found in association with other species in many larval habitats. In Madagascar, larval habitats are canoes, marshes, canals [67], swamps [103], tires, puddles, flooded lowlands [207], and rice fields [191]. Occurs in the Sambirano area (Nosy Be, Nosy Komba) [90], in the western, eastern, and central domains $[67,85]$. Not involved in disease transmission. In Africa, involved in transmission of NTAV [17], WNV [200], and many other viruses in the Central African Republic (SINV, BABV, Bobia virus [BIAV], MOSV, and KAMV) [1].

\subsection{Genus Mansonia Blanchard, 1901}

This genus is subdivided into two subgenera and includes 25 species in the world [119]. In Madagascar, only the subgenus Mansonoides occurs and it is represented by two species. Among them, Ma. africana was not reported to be present on the island [244]. Larvae grow in permanent waters containing aquatic plants and derive their oxygen by taking air from the aerenchyma of aquatic plants.

\subsubsection{Subgenus Mansonoides Theobald, 1907}

\section{- Mansonia (Mansonoides) africana (Theobald, 1901)} Grjebine, 1953 [103]

Eggs undescribed. Represented by two subspecies: the subspecies Ma. africana nigerrima confined to central Africa and Ma. africana africana present throughout the Afrotropical region and in Madagascar [120]. In Madagascar, occurs in the western domain [85, 103], anthropophilic [85]. In Africa, anthropophilic species [50]. Involved in transmission of SPOV [160], MIDV, PGAV, RVFV [45], RVFV [93], at least 13 arboviruses (Alphavirus, Flavivirus, Bunyaviruses, Phlebovirus) $[1,224]$ and Brugia patei [16].

\section{- Mansonia (Mansonoides) uniformis (Theobald, 1901)} Edwards, 1920 [75]

In Madagascar, larval habitats are ponds and rice fields [67]. Occurs in all Malagasy biogeographic domains (except the northern domain) [85]. Abundant, anthropophilic [85], zoophilic, nocturnal, and crepuscular species (Luciano Tantely, unpublished observation). Involved in transmission of RVFV, BABV, PERV [85], WNV [152], Wuchereria bancrofti [111], Setaria sp. and Dirofilaria spp. [23]. In Africa, zoophilic species in some areas and anthropophilic species in others [114].
Occasionally feeds on birds and bats [114]. In the world, involved in transmission of MIDV, Yata virus (YATV) [45], ZIKV, CHIKV [47], WNV [127], ONNV [151], RVFV [198], at least 16 arboviruses (Alphavirus, Flavivirus, Bunyaviruses, Orbivirus, Rhabdovirus, Phlebovirus) [1], and avian Plasmodium parasite (in Cameroon) [171].

\subsection{Genus Mimomyia Theobald, 1903}

The genera Mimomyia and Ficalbia belong to the Ficalbiini tribe. The genus Mimomyia includes 45 species subdivided into three subspecies: Etorleptiomyia (7 species), Ingramia (21 species), and Mimomyia (17 species) [119]. In Madagascar, 22 species were reported, and 17 of them are endemic. The phylogenetic relationship between the genus Mimomyia and other Culicidae genus remains uncertain, and the morphological data suggest affinity with the genera Ficalbia and Hodgesia [121]. The biology of genus Mimomyia remains poorly known. The species of this genus have no medical or veterinary importance in Madagascar, although some species were found naturally infected with arboviruses, particularly in Senegal [1].

\subsubsection{Subgenus Etorleptiomyia Theobald, 1904}

The subgenus Etorleptiomyia includes seven species, occurring mainly in the Ethiopian, eastern, and Australian regions. Two species were found in Madagascar, one being endemic to the island. The species of the subgenus Ertoleptiomyia breed in a wide variety of terrestrial water accumulations (marshes, ponds).

\section{- Mimomyia (Etorleptiomyia) martinei (Doucet, 1951)} Doucet, 1951 [66]

Endemic. Only the adult female was described [66]. Its existence and its membership to one subgenus were repeatedly questioned [157]. Without being able to provide indisputable evidence, some authors suggest that the description of the female stage could correspond to that of Mi. (Ingramia) spinosa $[110,157]$. If this were the case, these two species would be synonymous and retain the name Mimomyia martinei [110]. Pending further information, this species must be regarded as valid and inventoried in the Malagasy subgenus Ertoleptiomyia [119]. This endemic species was collected only once and is known only from the type locality (Périnet area) [66], where two adults were captured from an outdoor resting area, in hollow bamboo. This species was not found since that time.

\section{- Mimomyia (Etorleptiomyia) mediolineata (Theobald, 1904)}

Rodhain 1979 cited by [85]

Eggs undescribed. In Madagascar, larval habitats are coastal marshes, containing herbaceous plants (Cyperaceae, ferns), tannins, and plant organic matter [110]. Occurs in the Manakara and Taolagnaro regions (eastern domain), and the Mahajanga region (western domain) [85]. Captured in human 
landing catches [85]. In Africa, feeds mainly on amphibians and occasionally on humans [13].

\subsubsection{Subgenus Ingramia Edwards, 1912}

In total, among the 21 species described in subgenus Ingramia, 16 species occur only in Madagascar.

\section{- Mimomyia (Ingramia) aurata (Doucet, 1951)}

Doucet, 1951 [66]

Endemic. Eggs undescribed. Belongs to a complex of six species (Mi. aurata, Mi. bernardi, Mi. beytouti, Mi. collessi, Mi. marksae, Mi. mattinglyi) which are practically indistinguishable in the adult stage. Exhibits differences, sometimes marked, in the larval and pupal stages. Morphologically close to Mi. bernardi and Mi. beytouti. Larval habitats are leaf axils of Ravenala fronds [66, 85, 110] and leaf axils of Pandanus [110]. Occurs in the central and eastern domains [66, 85, 110]. Diurnal species and captured in human landing catches [85]. Not involved in disease transmission.

\section{- Mimomyia (Ingramia) bernardi (Doucet, 1950)}

Doucet, 1950 [65]

Endemic. Eggs undescribed. Belongs to the complex of six species cited above. All developmental stages are morphologically close to those of Mi. aurata. Larval habitats are in axils of Ravenala and Pandanus fronds in forested area [65]. Occurs in a large part of the eastern domain [65]. Biology unknown. Not involved in the transmission of disease.

\section{- Mimomyia (Ingramia) beytouti (Doucet, 1951)}

Doucet, 1951 [67]

Endemic. Eggs undescribed. Belongs to the complex of six species cited above. Morphologically close to Mi. collessi in the larval stage. Shows significant differences in the pupal stage. Larval habitats are leaf axils of Ravenala [67, 110]. Occurs in eastern domain [110]. Biology unknown. Not involved in disease transmission.

\section{- Mimomyia (Ingramia) brygooi Grjebine, 1986} Grjebine, 1986 [110]

Endemic. Adult female and eggs undescribed. Because of the similarity between the larval stages within the subgenus Ingramia, larval capture data may refer to one of the following species: Mi. brygooi, Mi. levicastilloi, and Mi. longicornis, or to Mi. ramalai. The only adult stage known is the two males used in the original description, they were obtained from larval rearing. Larval habitats are leaf axils of Pandanus and Ravenala [85]. Occurs in the eastern domain [110]. Adult biology unknown. Not involved in disease transmission.

\section{- Mimomyia (Ingramia) collessi Grjebine, 1986}

Grjebine, 1986 [110]

Endemic. Eggs undescribed. Belongs to the complex of six species cited above. Morphologically close to Mi. beytouti. Occurs mainly in the eastern domain [110]. Adult biology unknown. Not involved in disease transmission.

\section{- Mimomyia (Ingramia) jeansottei (Doucet, 1950)} Doucet, 1950 [65]

Endemic. Eggs undescribed. Larval habitats are leaf axils of Ravenala, and Nepenthes madagascariensis pitchers of the coastal peatlands. Only occurs on the eastern coast of Madagascar [27, 109, 110]. Adult biology unknown. Not involved in disease transmission.

\section{- Mimomyia (Ingramia) levicastilloi Grjebine, 1986} Grjebine, 1986 [110]

Endemic. Adult stage and eggs undescribed. Larval habitats are leaf axils of Pandanus. Occurs along the coastal dunes of the eastern domain [110].

\section{- Mimomyia (Ingramia) longicornis Grjebine, 1986} Grjebine, 1986 [110]

Endemic. Eggs undescribed. Larval habitats are leaf axils of large Pandanus, in the forested zone. Adult biology unknown because adult stages were known only from larval rearing [110]. Collected only once and known only from the type locality (Ambodirina Forest), in the eastern domain, at the boundary between the eastern and central highlands. Not involved in disease transmission.

\section{- Mimomyia (Ingramia) marksae Grjebine, 1986} Grjebine, 1986 [110]

Endemic. Eggs undescribed. Belongs to a complex of species morphologically closes, including Mi. beytouti, Mi. collessi, and Mi. marksae. Larval habitats are leaf axils of Ravenala, in the eastern domain. Adult biology unknown because adults were known only from larval rearing [110]. Not involved in disease transmission.

\section{- Mimomyia (Ingramia) mattinglyi Grjebine, 1986} Grjebine, 1986 [110]

Endemic. Adult female and eggs undescribed. The only known male was obtained from larval holotype rearing. Larval habitats are leaf axils of Ravenala. Only occurs in the Andasibe forest of the eastern domain [110]. Adult biology unknown. Not involved in disease transmission.

\section{- Mimomyia (Ingramia) milloti Grjebine, 1986}

Grjebine, 1986 [110]

Endemic. Eggs undescribed. Belongs to a complex of species with Mimomyia roubaudi in Madagascar and Mi. grjebinei in the Comoros archipelago. Larval habitats are leaf axils of Arum (Colocasia sp. and Typhonodorum) and Pandanus. Collected in the central domain [110]. Adult biology unknown. No medical and veterinary importance.

\section{- Mimomyia (Ingramia) ramalai Grjebine, 1986} Grjebine, 1986 [110]

Endemic. Adult male and egg undescribed. The two females, used in the description, were obtained from larval rearing. Larval habitats are leaf axils of Pandanus. Collected only once and known only from the type locality (Mandraka forest). Morphologically close to Mimomyia brygooi. Adult biology unknown. Not involved in disease transmission. 


\section{- Mimomyia (Ingramia) roubaudi (Doucet, 1950)}

Doucet, 1950 [65]

Endemic. Eggs undescribed. Belongs to a complex of species with Mimomyia milloti which occurs in Madagascar and Mi. grjebinei in the Comoros archipelago. Morphological variations observed from specimens collected in the Vohipeno region, allowing us to assume the presence of a complex of species. Larval habitats are mainly the leaf axils of Typhonodorum sp. and exceptionally the axils of fronds of Ravenala. Occurs in the eastern domain and locally on the west coast of Madagascar (Nosy Be, Morondava, and Mahajanga regions) [103]. Adult biology unknown. Not involved in disease transmission.

\section{- Mimomyia (Ingramia) spinosa (Doucet, 1951)}

Doucet, 1951 [66]

Endemic. Eggs undescribed. Redescription of specimens collected in Analamazaotra forest near Périnet forest, allowed Grjebine [110] to suggest that this species is a synonym of Mimomyia martinei, without providing any evidence [110]. Larval habitats are mainly axils of fronds of Ravenala and bamboo [66]. Occurs in the eastern domain [66, 110]. Adult biology unknown. Not involved in disease transmission.

\section{- Mimomyia (Ingramia) stellata Grjebine, 1986}

Grjebine, 1986 [110]

Endemic. Eggs undescribed. Larval habitats are axils of fronds of Ravenala and bamboo. Only occurs in the Moramanga region (Périnet, Mandraka, and Lakato) in forested areas of the eastern domain. Adults are known only from larval rearing [110]. Not involved in disease transmission.

\section{- Mimomyia (Ingramia) vansomerenae Grjebine, 1986} Grjebine, 1986 [110]

Endemic. Only the larval stages were described [110]. Known only from the type locality (Lokobe Reserve, Nosy $\mathrm{Be}$ ). Larval habitats are axils of fronds of Ravenala [110].

\subsubsection{Subgenus Mimomyia Theobald, 1903}

The subgenus Mimomyia includes 21 species, widely distributed throughout the Ethiopian and Oriental regions and extends to northern Australia and the South Pacific. The four Malagasy species have a wide distribution on the African mainland. The report of Mi. lacustris Edwards and Mi. pallida Edwards as present in Madagascar in the Arim dataset [5] is doubtful as information on collection areas is not available. De facto this information was treated as an error. The species of the subgenus Mimomyia develop in a wide variety of terrestrial water accumulations (ponds, marshes, ponds, and riverbanks).

\section{- Mimomyia (Mimomyia) hispida (Theobald, 1910)}

Doucet, 1951 [66]

Eggs undescribed. In Madagascar, larval habitats are ponds and marshes containing abundant aquatic vegetation [110], muddy swamp water and rice fields with low vegetation [67]. Occurs in the central and eastern domains [65, 67, 85, 110]. Adult biology unknown. In Africa, caught in human biting catches in West Africa [155] and feeds mainly on amphibians and cattle in Kenya [13]. Involved in transmission of BABV, BAGV, and WNV [222].

\section{- Mimomyia (Mimomyia) mimomyiaformis (Newstead, 1907)}

Doucet, 1951

Eggs undescribed. In Madagascar, larval habitats are stagnant or slow moving water, with aquatic vegetation (swamps, irrigation canals, and rivers) within forested areas [66]. Occurs in the eastern domain, western coastal plains, in the Mahajanga region [110]. Adult biology unknown. In Africa, captured in human biting catches [155]. Not involved in disease transmission.

\section{- Mimomyia (Mimomyia) plumosa (Theobald, 1901)}

Doucet, 1951 [67]

Eggs undescribed. In Madagascar, larval habitats are forest ponds with vegetation [110]. Occurs in the eastern domain (Périnet and Vangaindrano) and the Sambirano area. Adult biology unknown. Not involved in disease transmission. Adult biology unknown. In Africa, involved in transmission of Bunyaviruses of the Bwamba Group, a non-pathogenic virus to humans [1].

\section{- Mimomyia (Mimomyia) splendens Theobald, 1903} Grjebine, 1956

Eggs undescribed. In Madagascar, larval habitats are terrestrial water accumulations, invariably associated with aquatic plants, indispensable for breathing larvae. Occurs throughout the eastern domain, from the eastern margin of the central highlands (Moramanga Périnet) to the coastal lagoons of the south-eastern domain (Manakara and Vangaindrano regions). Also reported locally in the western domain (Mahajanga region). In Africa, feeds mainly on amphibians and occasionally on humans [13]. Involved in transmission of WNV, BABV, and BAGV [1].

\subsection{Genus Orthopodomyia Theobald, 1904}

This genus is represented by 36 species in the world [119]. Eight species occur in Madagascar. The Malagasy species belong to Group Vernoni and are all endemic to Madagascar. They are not involved in disease transmission.

\section{- Orthopodomyia ambremontis Brunhes \& Hervy, 1995} [27]

Brunhes \& Hervy, 1995 [27]

Endemic. Eggs and adult female undescribed. Larval habitats are tree holes. Occurs in the Montagne d'Ambre, at altitudes above about $1200 \mathrm{~m}$ asl, in the northern domain [27]. Adult biology unknown.

- Orthopodomyia ankaratrensis Brunhes \& Hervy, 1995 [27]

Brunhes \& Hervy, 1995 [27]

Endemic. Eggs, pupal and adult stages undescribed. Larval habitats are tree holes. Collected only once and known only 
from the type locality (Manjakatompo, Ankaratra massif), at altitudes above about $1800 \mathrm{~m}$, in the central domain. Adult biology unknown [27].

\section{- Orthopodomyia fontenillei Brunhes \& Hervy, 1995 [27]}

Brunhes \& Hervy, 1995 [27]

Endemic. Eggs undescribed. Larval habitats are tree holes. Occurs in forested areas, at an altitude greater than $80 \mathrm{~m}$ asl of the eastern [27] and central domains [207]. Adult biology and larval habitats unknown.

\section{- Orthopodomyia milloti Doucet, 1951 [66]}

Doucet, 1951 [66]

Endemic. Eggs undescribed. Larval habitats are tree holes, leaf axils of Pandanus and Ravenala and bamboo [85, 182, 207], and ovitraps [85]. Occurs in the eastern and central domains and seems to be frequent at lower altitudes (below $800-900 \mathrm{~m}$ ): from the sea to the eastern margins of the central highlands [27, 85]. Adult biology unknown.

\section{- Orthopodomyia rajaonariveloi Brunhes \& Hervy, 1995} [27]

Brunhes \& Hervy, 1995 [27]

Endemic. Only known from the holotype female [27]. Biology unknown. Occurs only in the Fenoarivo Atsinanana region of the eastern domain [27].

\section{- Orthopodomyia ravaonjanaharyi Brunhes \& Hervy,} 1995 [27]

Brunhes \& Hervy, 1995 [27]

Endemic. Eggs undescribed. Larval habitats are tree holes (Albizzia, mango tree). Only occurs in the Sambava and Antalaha regions, on the north-eastern coast of Madagascar. Adult biology unknown.

\section{- Orthopodomyia rodhaini Brunhes \& Hervy, 1995 [27]} Brunhes \& Hervy, 1995 [27]

Endemic. Egg and adult stages undescribed. Larval habitats are tree holes and cut bamboo. Only occurs in Antongil Bay, in the eastern domain [27].

\section{- Orthopodomyia vernoni van Someren, 1949 [229]} van Someren, 1949 [229]

Endemic. Eggs undescribed. Larval habitats are many phytotelmata but sometimes artificial containers (tin cans and metal cans) [27, 85]. Occurs in the western and southern domains of Madagascar, and can reach areas bordering other bioclimatic domains, at lower altitude (below $1000 \mathrm{~m}$ ).

\subsection{Genus Toxorhynchites Theobald, 1901}

This genus includes four subgenera represented by 89 species in the world [119]. Six species occur in Madagascar. This study did not include Tx. brevipalpis that is reported to be present on the island by WRBU [244]. The Malagasy species belong only to the subgenus Afrorhynchus which dominates on the African mainland, and within the Group Pauliani which is endemic to Madagascar [190]. The external morphology of this group is homogeneous. Only male genitalia morphology allows differentiation of these species. The adult stages of Toxorhynchites are phytophagous and are not involved in transmission of pathogens. The larval stages are predators feeding on larval stages of other mosquito species. Its host preference allows us to consider Toxorhynchites mosquitoes as a biological control agent of vector mosquitoes [190]. In Madagascar, Toxorhynchites larva develops generally in many phytotelmata: Typhonodorum, Ravenala, Pandanus, Nepenthes madagascarensis, Colocasia, bamboo, and fruit shells [111]. Most Malagasy Toxorhynchites species occur in the eastern biogeographic domain [67, 190]. Larval stages of this genus were collected by Rodhain et al. [195] in the Mahajanga area, of the western domain, but remained unidentified. The adult biology of Toxorhynchites of Madagascar is unknown and the Malagasy species has no medical or veterinary importance.

\section{- Toxorhynchites (Afrorhynchus) brunhesi Ribeiro, 2004 [190]}

Ribeiro, 2004 [190]

Endemic. Eggs undescribed. The holotype male was collected in the Moramanga district located in the eastern domain, on the eastern margin of the central highlands.

\section{- Toxorhynchites (Afrorhynchus) fontenillei Ribeiro, 2004 [190] \\ Ribeiro, 2004 [190]}

Endemic. Eggs, larval and pupal stages and adult female undescribed. The holotype male was obtained from larval rearing after collection in Ravenala, in the rainforest park of Analamazaotra (Périnet forest).

\section{- Toxorhynchites (Afrorhynchus) grjebinei Ribeiro, 2004 [190] \\ Ribeiro, 2004 [190]}

Endemic. Eggs undescribed. Larval habitats are Ravenala, as shown on one of the two labels of the holotype [190]. Occurs in the Périnet region, and in the Sainte-Luce region, far south-east of Madagascar [190].

\section{- Toxorhynchites (Afrorhynchus) lemuriae Ribeiro, 2004 [190]}

Ribeiro, 2004 [190]

Endemic. Only described and known from holotype female, which was collected in the Manakara region of the eastern domain [190].

\section{- Toxorhynchites (Afrorhynchus) madagascarensis Ribeiro, 2004 [190] \\ Ribeiro, 2004 [190] \\ Endemic. Eggs undescribed. The holotype male was obtained from larval rearing after collection in Ravenala. Known only from the Taolagnaro area, in the eastern domain [67].}

\section{- Toxorhynchites (Afrorhynchus) pauliani (Doucet, 1951) [67]}

Doucet, 1951 [67] 
Endemic. Only known from the holotype male, which was collected by Doucet from an outdoor area (in leaf of Ravenala) in Vangaindrano city, in 1950 [67].

\subsection{Genus Uranotaenia Lynch Arribálzaga, 1891}

Genus Uranotaenia is the only genus of Culicidae belonging to the tribe Uranotaeniini. This genus is subdivided into two subgenera and includes 267 species in the world: the subgenus Pseudoficalbia (146 species) and the subgenus Uranotaenia (121 species) [119]. The genus Uranotaenia occurs on all continents, with the exception of the Pacific Ocean islands and Antarctica. This genus is particularly well represented in the Afrotropical and Oriental regions. In Madagascar, a comprehensive and complete systematic revision was carried out on the genus Uranotaenia [51]. With this revision, the genus Uranotaenia is the best represented and probably the best known genus, regarding the number of species in Madagascar. Among 73 Malagasy species belonging to this genus, 65 species are endemic, and four species occur only in Madagascar and in the Comoros archipelago. Although we have little information on the host preferences and behavior of adults, we know that these mosquitoes prefer to feed on cold-blooded animals (reptiles, amphibians), and nevertheless are probably involved in disease transmission.

\subsubsection{Subgenus Pseudoficalbia Theobald, 1912 [221]}

All Malagasy species $(n=52)$ of this subgenus are endemic. This study did not include Ur. comorensis, Ur. fusca, Ur. mashonaensis, Ur. nepenthes, Ur. ornate, Ur. pandani, and $U r$. shillitonis that were reported to be present on the island by WRBU [244]. The larval habitats are always associated with small breeding sites and phytotelmata.

\section{- Uranotaenia (Pseudoficalbia) albimanus da Cunha} Ramos \& Brunhes, 2004 [51]

da Cunha Ramos \& Brunhes, 2004 [51]

Endemic. Egg and larval stages undescribed. Belongs to the Annulata section (Lavieri Group). Larval habitats are leaf axils of Ravenala. Collected only once and known only from the type locality (coastal forests of the Manakara region), in the eastern domain [51].

\section{- Uranotaenia (Pseudoficalbia) albinotata da Cunha} Ramos \& Brunhes, 2004 [51]

da Cunha Ramos \& Brunhes, 2004 [51]

Endemic. Eggs undescribed. Belongs to section and group Shillitonis. Larval habitats are cut bamboo. Occurs only in the Manakara region, in the eastern domain.

\section{- Uranotaenia (Pseudoficalbia) ambodimanga da Cunha Ramos \& Brunhes, 2004 [51] \\ da Cunha Ramos \& Brunhes, 2004 [51]}

Endemic. Eggs, larval and pupal stages undescribed. Belongs to section Annulata (Lavieri Group). Larval habitats are dried bamboo. Collected only once and known only from the type locality (Ambodimanga, Moramanga region) [51].

\section{- Uranotaenia (Pseudoficalbia) antalahaensis da Cunha Ramos \& Brunhes, 2004 [51]}

da Cunha Ramos \& Brunhes, 2004 [51]

Endemic. Eggs, larval stages and adult male undescribed. Belongs to section Spinosa. Larval habitats are rotten Ravenala trunks containing plant organic matter. Collected on one occasion in the Masoala National Park, in the eastern domain [51].

\section{- Uranotaenia (Pseudoficalbia) apicosquamata da} Cunha Ramos \& Brunhes, 2004 [51]

da Cunha Ramos \& Brunhes, 2004 [51]

Endemic. Eggs undescribed. Belongs to section Annulata (Lavieri Group). Larval habitats are sectioned Ravenala trunks, bamboo, mango tree trunks, and rock holes. Occurs in the eastern and western domains and in the Sambirano area (Nosy Be) [51].

\section{- Uranotaenia (Pseudoficalbia) bambusicola da Cunha Ramos \& Brunhes, 2004 [51]}

da Cunha Ramos \& Brunhes, 2004 [51]

Endemic. Eggs and adult male undescribed. Belongs to section and group Shillitonis. Larval habitats are cut bamboo. Occurs in the eastern domain, at altitudes around $1000 \mathrm{~m}$.

\section{- Uranotaenia (Pseudoficalbia) belkini Grjebine, 1979 [109]}

Grjebine, 1979 [109]

Endemic. Eggs undescribed. Belongs to section and group Shillitonis. Larval habitats are Nepenthes madagascariensis pitchers. Occurs on the south-eastern coast of Madagascar from Manakara to Taolagnaro.

\section{- Uranotaenia (Pseudoficalbia) bicincta da Cunha Ramos \& Brunhes, 2004 [51]}

da Cunha Ramos \& Brunhes, 2004 [51]

Endemic. Eggs and adult female undescribed. Belongs to section Shillitonis, sole representative of the Bicincta Group. Larval habitats are cut bamboo. Occurs in the Sambirano area (Nosy $\mathrm{Be})$ and in the Antalaha region of the eastern domain [51].

\section{- Uranotaenia (Pseudoficalbia) bifasciata da Cunha Ramos \& Brunhes, 2004 [51]}

da Cunha Ramos \& Brunhes, 2004 [51]

Endemic. Eggs and adult male undescribed. Belongs to section Annulata (Lavieri Group). Larval habitats are crab holes. Collected only once and known only from the type locality (Nosy Mangabe, in Antongil Bay in the eastern domain) [51].

\section{- Uranotaenia (Pseudoficalbia) bosseri Grjebine, 1979} [109]

Grjebine, 1979 [109]

Endemic. Eggs undescribed. Belongs to section Nigripes. Larval habitats are Nepenthes madagascariensis pitchers 
[109]. Occurs from the Manakara region to the Amboasary region, from the eastern domain to the southern domain boundary [51].

\section{- Uranotaenia (Pseudoficalbia) boussesi da Cunha Ramos \& Brunhes, 2004 [51] \\ da Cunha Ramos \& Brunhes, 2004 [51] \\ Endemic. Eggs, pupal and adult stages undescribed. Larval stages are morphologically close to those of Uranotaenia rave- nalicola. Belongs to section Nigripes. Larval habitats are leaf axils of Ravenala. Collected only once and known only from the type locality (Ampasinalotra, in the Brickaville region of the eastern domain) [51].}

\section{- Uranotaenia (Pseudoficalbia) breviseta da Cunha Ramos \& Brunhes, 2004 [51]}

da Cunha Ramos \& Brunhes, 2004 [51]

Endemic. Eggs, larval stages and adult female undescribed. Belongs to section Annulata (Lavieri Group). Description of larva unknown. The larvae develop in Ravenala trunks. This species was collected only once and is known only from the type locality (coastal forest of Manakara of the eastern domain) [51].

\section{- Uranotaenia (Pseudoficalbia) brumpti Doucet, 1951 [67]}

Doucet, 1951 [67]

Endemic. Eggs undescribed. Belongs to section Nigripes. Larval habitats are dry dead leaves of Ravenala, clear waters [67], puddles on tree trunks, banana leaves, and cut bamboo [51]. Occurs in the eastern domain [51], from sea level up to $1000 \mathrm{~m}$.

\section{- Uranotaenia (Pseudoficalbia) brunhesi Grjebine, 1979 [109] \\ Grjebine, 1979 [109]}

Endemic. Eggs undescribed. Belongs to section and group Shillitonis. Larval habitats are Nepenthes madagascarensis pitchers, in the Taolagnaro region of the far south-east of Madagascar [50, 109].

\section{- Uranotaenia (Pseudoficalbia) cachani (Doucet, 1950) [65] \\ Doucet, 1950 [65]}

Endemic. Eggs undescribed. Belongs to section Nigripes. Larval stages were formerly described as Aedes (Skusea) cachani by Doucet [65], classified in the genus Uranotaenia in 1955 by Mattingly \& Brown [156]. Larval habitats are only the leaf axils of Typhonodorum lindleyanum. Occurs in the eastern and central domains [51].

\section{- Uranotaenia (Pseudoficalbia) carcinicola da Cunha Ramos \& Brunhes, 2004 [51]}

da Cunha Ramos \& Brunhes, 2004 [51]

Endemic. Eggs undescribed. Belongs to section Annulata, and sole representative of the Annulata Group. Larval habitats are crab holes. Collected only once and known only from the type locality (Nosy Mangabe in Antongil Bay).

\section{- Uranotaenia (Pseudoficalbia) combesi Doucet, 1950 [65] \\ Doucet, 1950 [65]}

Endemic. Eggs undescribed. Belongs to section Nigripes. Larval habitats are rock holes, pools near rice fields [65], bamboos resting on the beach, and basin cement. Occurs in the eastern, western, central, and southern domains [51, 65].

\section{- Uranotaenia (Pseudoficalbia) contrastata da Cunha Ramos \& Brunhes, 2004 [51] \\ da Cunha Ramos \& Brunhes, 2004 [51]}

Endemic. Eggs, larval stages and adult male undescribed. Belongs to section and group Shillitonis. Larval habitats are cut bamboo. Collected only once and known only from the type locality (Ambodimanga village, in Moramanga district, at altitudes of about 400 to $500 \mathrm{~m}$ ) [51].

- Uranotaenia (Pseudoficalbia) cornuta da Cunha Ramos \& Brunhes, 2004 [51]

da Cunha Ramos \& Brunhes, 2004 [51]

Endemic. Eggs and adult male undescribed. This species belongs to section Spinosa. Larval habitats are leaf axils of Pandanus, exposed to the sun or located in forested areas. Occurs in the Lakato region (Moramanga district) and in the locality near the Bay of Saint-Luce (Taolagnaro region) of the eastern domain [51].

\section{- Uranotaenia (Pseudoficalbia) damasei Grjebine, 1979} [109]

Grjebine, 1979 [109]

Endemic. Eggs and adult stages undescribed. Belongs to section and group Shillitonis. Larval habitats are Nepenthes madagascariensis pitchers. Occurs on the south-eastern coast: from Manakara to Sainte-Luce [50, 109].

\section{- Uranotaenia (Pseudoficalbia) donai da Cunha Ramos \& Brunhes, 2004 [51]}

da Cunha Ramos \& Brunhes, 2004 [51]

Endemic. Eggs, pupal and adult stages undescribed. Belongs to section and group Shillitonis. Larval habitats are Nepenthes madagascariensis pitchers, often hidden in sphagnum. Present only in the Taolagnaro region of the eastern domain [51].

\section{- Uranotaenia (Pseudoficalbia) douceti Grjebine, 1953 [103]}

Grjebine, 1953 [103]

Endemic. Eggs undescribed. This species belongs to section Nigripes. Larval habitats are leaf axils of Typhonodorum lindleyanum and Pandanus [103, 182]. Occurs in the Sambirano area, western and eastern domains. Widely distributed at altitudes below $100 \mathrm{~m}$ asl [51, 103].

\section{- Uranotaenia (Pseudoficalbia) fulgens da Cunha Ramos \& Brunhes, 2004 [51] \\ da Cunha Ramos \& Brunhes, 2004 [51]}

Endemic. Egg, pupal stages and adult male undescribed. Belongs to section and group Shillitonis. Larval habitats are 
cut bamboo. Occurs in the Moramanga region of the eastern domain [51].

\section{- Uranotaenia (Pseudoficalbia) grenieri Doucet, 1951} [67]

Doucet, 1951 [67]

Endemic. Eggs undescribed. Belongs to section Nigripes. Morphologically close to Ur. ornata Theobald, which is absent from Madagascar. Larval habitats are dead leaves of Ravenala [67], leaf axils of Typhonodorum and Pandanus, gutters, mushrooms horns, rock holes, fallen tree trunks, puddles, and streams [51]. Occurs in the central and eastern domains. Abundant from eastern seaboard up to $1200 \mathrm{~m}$ asl [51].

\section{- Uranotaenia (Pseudoficalbia) grjebinei da Cunha} Ramos \& Brunhes, 2004 [51]

da Cunha Ramos \& Brunhes, 2004 [51]

Endemic. Eggs undescribed. Belongs to section Spinosa. Larval habitats are leaf axils of Pandanus. Occurs in the eastern domain [51].

\section{- Uranotaenia (Pseudoficalbia) haddowi da Cunha} Ramos \& Brunhes, 2004 [51]

da Cunha Ramos \& Brunhes, 2004 [51]

Endemic. Eggs undescribed. Belongs to section Annulata (Lavieri Group). Larval habitats are mango tree trunks, Kapok trees, and Ravenala. Occurs in the Sambirano area (Nosy Be), northern, western, and eastern domains, always on coastal plains.

\section{- Uranotaenia (Pseudoficalbia) hirsuta Boussès \& Brunhes, 2013 [14] \\ Boussès \& Brunhes, 2013 [14]}

Endemic. Eggs, pupal and adult stages undescribed. Belongs to section Annulata (Lavieri Group). Larval habitats are rock holes. Collected only once and known only from the type locality (Ambovanomby forest, in the Namoroka reserve of Mahajanga Province).

\section{- Uranotaenia (Pseudoficalbia) hervyi da Cunha Ramos} \& Brunhes, 2004 [51]

da Cunha Ramos \& Brunhes, 2004 [51]

Endemic. Eggs undescribed. Belongs to section and group Shillitonis. Larval habitats are water retained in cut or broken bamboo. Occurs in the Moramanga region of the eastern domain [51].

\section{- Uranotaenia (Pseudoficalbia) kraussi Grjebine, 1953 [103]}

Grjebine, 1953 [103]

Endemic. Eggs undescribed. Belongs to section Nigripes. Larval habitats are leaf axils of Taro [103] and Typhonodorum sp., banana leaves, bamboo, and mushroom caps [51]. Carnivorous larvae, which feed on mosquito larvae of the same or other species. Rare species, but widely distributed throughout Montagne d'Ambre in the northern domain, Mandraka in Antananarivo province, Ikongo of Fianarantsoa province in the central domain, and Andasibe forest in the eastern domain [51].
- Uranotaenia (Pseudoficalbia) laffosseae da Cunha Ramos \& Brunhes, 2004 [51]

da Cunha Ramos \& Brunhes, 2004 [51]

Endemic. Eggs undescribed. Belongs to section Nigripes. Larval habitats are cut bamboo and tree holes [51] and axils of Typhonodorum in Mayotte [145]. This species is present in Madagascar and Mayotte [145]. In Madagascar, occurs in the eastern domain and in the Montagne d'Ambre of the northern domain [51].

\section{- Uranotaenia (Pseudoficalbia) lavieri Doucet, 1950 [65]} Doucet, 1950 [65]

Endemic. Eggs and adult stages undescribed. Belongs to section Annulata (representative of the nominal group). Larval habitats are cut bamboo [66] and tree holes [51]. Occurs in the Sambirano area (Nosy Be, Nosy Komba) [90], in rainforests of the eastern [66] and northern domains [51].

\section{- Uranotaenia (Pseudoficalbia) legoffi da Cunha Ramos \& Brunhes, 2004 [51]}

da Cunha Ramos \& Brunhes, 2004 [51]

Endemic. Eggs undescribed. Belongs to section Spinosa. Larval habitats are bamboo and leaf axils of Pandanus on the Pangalana canal. Occurs from the Brickaville region to the margins of the eastern domain, up to $500 \mathrm{~m}$ asl [51].

\section{- Uranotaenia (Pseudoficalbia) longitubus da Cunha} Ramos \& Brunhes, 2004 [51]

da Cunha Ramos \& Brunhes, 2004 [51]

Endemic. Eggs, pupal and adult stages undescribed. Belongs to section Annulata (Lavieri Group). Larval habitats are cut bamboo. Collected only once and known only from the type locality (Masoala island in the eastern domain) [51].

\section{- Uranotaenia (Pseudoficalbia) lousthei Boussès \&} Brunhes, 2013 [14]

Boussès \& Brunhes, 2013 [14]

Endemic. Only the larval stages were described [14]. Belongs to section Spinosa [51]. Larval habitats are leaf axils of Pandanus along the beachfront. Collected only once and known only from the type locality (Ambila-Lemaitso, Toamasina province of the eastern domain).

- Uranotaenia (Pseudoficalbia) madagascarensis da Cunha Ramos \& Brunhes, 2004 [51]

da Cunha Ramos \& Brunhes, 2004 [51]

Endemic. Eggs undescribed. Belongs to section and group Shillitonis. Larval habitats are cut bamboo. Occurs in the eastern domain, from sea level up to $1000 \mathrm{~m}$ altitude [51].

- Uranotaenia (Pseudoficalbia) manakaraensis da Cunha Ramos \& Brunhes, 2004 [51]

da Cunha Ramos \& Brunhes, 2004 [51]

Endemic. Eggs and larval stages undescribed. Belongs to section Annulata (Lavieri Group). Larval habitats are Ravenala trunks. Occurs only in the Manakara region, in the eastern domain [51]. 


\section{- Uranotaenia (Pseudoficalbia) nigricephala da Cunha Ramos \& Brunhes, 2004 [51] \\ da Cunha Ramos \& Brunhes, 2004 [51] \\ Endemic. Eggs undescribed. Belongs to section Nigripes. Larval habitats are leaf axils of Typhonodorum and Pandanus sp. Occurs in the eastern domain.}

\section{- Uranotaenia (Pseudoficalbia) nigripleura da Cunha} Ramos \& Brunhes, 2004 [51]

da Cunha Ramos \& Brunhes, 2004 [51]

Endemic. Eggs and larval stages undescribed. Belongs to section Spinosa. Larval habitats are leaf axils of Ravenala along the beachfront of the eastern domain [51].

\section{- Uranotaenia (Pseudoficalbia) pallidipleura da Cunha} Ramos \& Brunhes, 2004 [51]

da Cunha Ramos \& Brunhes, 2004 [51]

Endemic. Further description of egg and larval stages will perhaps help to distinguish $U r$. pallidipleura from $U r$. donai [51]. Belongs to section and group Shillitonis. Larval habitats are Nepenthes madagascariensis pitchers. Occurs on the southeastern coast of Madagascar.

\section{- Uranotaenia (Pseudoficalbia) pauliani Doucet, 1949 [64]}

Doucet, 1949 [64]

Endemic. Only the larval stages were described [64]. Belongs to section Nigripes. Formerly synonymized with $U r$. nepenthes and $U r$. pandani which are endemic to the Seychelles archipelago [124, 156]. Morphologically close to Ur. ornate which is absent from Madagascar [64]. Only type series of larval stages were caught to date. Larval habitats are dried leaf rachis of Neodypsis on the ground. Collected only once. Known only from the type locality (Ambohiby, Tsiroanomandidy region in the central domain) [64].

\section{- Uranotaenia (Pseudoficalbia) pilosa da Cunha Ramos} \& Brunhes, 2004 [51]

da Cunha Ramos \& Brunhes, 2004 [51]

Endemic. Eggs and adult female undescribed. Belongs to section Spinosa. Larval habitats are leaf axils of Pandanus throughout the beachfront to the mountainous regions of the eastern slopes. Occurs in the central and eastern domains.

\section{- Uranotaenia (Pseudoficalbia) pseudoalbimanus da} Cunha Ramos \& Brunhes, 2004 [51]

da Cunha Ramos \& Brunhes, 2004 [51]

Endemic. Eggs undescribed. Belongs to section Annulata (Lavieri Group). Larval habitats are Ravenala trunks and cut bamboo. Occurs in the central and eastern domains [51]. Frequent in humid forest areas or areas formerly occupied by forest.

- Uranotaenia (Pseudoficalbia) pseudoshillitonis da Cunha Ramos \& Brunhes, 2004 [51]

da Cunha Ramos \& Brunhes, 2004 [51]
Endemic. Eggs undescribed. Belongs to section and group Shillitonis. Larval habitats are cut bamboo. Occurs in the central and eastern domains [51].

\section{- Uranotaenia (Pseudoficalbia) ravenalaphila Boussès \& Brunhes, 2013 [14]}

Boussès \& Brunhes, 2013 [14]

Endemic. Only the larval stages were described [14]. Belongs to section Annulata. Larval habitats are cut trunks of Ravenala madagascariensis containing brown water and rotting vegetable matter. Its larval stages are usually found in association with Uranotaenia haddowi, Ur. manakaraensis, Ur. albimanus, and Ur. breviseta. Collected only once and known only from the type locality (Ifaho, Manakara region of the eastern domain).

\section{- Uranotaenia (Pseudoficalbia) ravenalicola da Cunha} Ramos \& Brunhes, 2004 [51]

da Cunha Ramos \& Brunhes, 2004 [51]

Endemic. Eggs undescribed. Belongs to section Nigripes. Morphologically close to Ur. boussesi. Larval habitats are leaf axils of Ravenala. Occurs in the eastern domain, from sea level up to about $1000 \mathrm{~m}$ asl.

\section{- Uranotaenia (Pseudoficalbia) scutostriata da Cunha} Ramos \& Brunhes, 2004 [51]

da Cunha Ramos \& Brunhes, 2004 [51]

Endemic. Eggs undescribed. Belongs to section Annulata (Lavieri Group). Larval habitat is bamboo forest. Collected only once and known only from the type locality (Ambodimanga, Moramanga region of the eastern domain) [51].

\section{- Uranotaenia (Pseudoficalbia) spinitubus da Cunha} Ramos \& Brunhes, 2004 [51]

da Cunha Ramos \& Brunhes, 2004 [51]

Endemic. Only the larval stages were described [51]. Belongs to section Annulata (Lavieri Group). Larval habitats are tree holes. Occurs in the northern and eastern domains [51].

\section{- Uranotaenia (Pseudoficalbia) spinosa da Cunha} Ramos \& Brunhes, 2004 [51]

da Cunha Ramos \& Brunhes, 2004 [51]

Endemic. Eggs and adult male undescribed. Belongs to section Spinosa. Larval habitats are leaf axils of Pandanus on the beachfront of the eastern domain [51]

\section{- Uranotaenia (Pseudoficalbia) spiraculata da Cunha} Ramos \& Brunhes, 2004 [51]

da Cunha Ramos \& Brunhes, 2004 [51]

Endemic. Eggs undescribed. Belongs to section and group Shillitonis. Larval habitats are cut bamboo. Occurs in the eastern domain, and is particularly abundant in the eastern forest (Beforona, Périnet), at an altitude between 500 and $1000 \mathrm{~m}$.

\footnotetext{
- Uranotaenia (Pseudoficalbia) tricolor da Cunha Ramos \& Brunhes, 2004 [51]

da Cunha Ramos \& Brunhes, 2004 [51]
} 
Endemic. Only the larval stages were described [51]. Belongs to section Spinosa. Larval habitats are leaf axils of Pandanus along the beachfront of the eastern coast.

\section{- Uranotaenia (Pseudoficalbia) tridentata da Cunha Ramos \& Brunhes, 2004 [51] \\ da Cunha Ramos \& Brunhes, 2004 [51]}

Endemic. Only the larval stages were described [51]. Belongs to section and group Shillitonis. Larval habitats are bamboo. Occurs in the eastern domain, between 800 and $1000 \mathrm{~m}$ asl.

\section{- Uranotaenia (Pseudoficalbia) tsaratananae Doucet, 1950 [65] \\ Doucet, 1950 [65]}

Endemic. Eggs undescribed. Belongs to section Nigripes. Larval habitats are tree holes [65], palm tree forming a gutter, coconuts, and the leaf axils of Pandanus [51]. Occurs in high altitude forests of the eastern and northern domains [51], between 700 and $1700 \mathrm{~m}$ asl.

\subsubsection{Subgenus Uranotaenia Lynch Arribálzaga, 1891}

This subgenus includes 21 species in Madagascar. Among them, $U r$. alba was reported to be absent from the island by WRBU [244]. Fourteen species are endemic to the island, three are found in Madagascar and in the Comoros archipelago, and only four are African-Malagasy species.

\section{- Uranotaenia (Uranotaenia) alba Theobald, 1901}

Doucet, 1951 [67]

Eggs undescribed. Belongs to section Alba (Alba Group). Larval habitats are muddy rice fields. Occurs in the eastern domain [51, 67].

\section{- Uranotaenia (Uranotaenia) alboabdominalis Theobald, $1910[220]$}

Doucet, 1951 [67]

Eggs undescribed. Belongs to section Alba (Alba Group). Larval habitats are swamps, puddles under forest cover, and ponds [67]. Occurs mainly in the eastern domain and in the Mahajanga region of the western domain [51].

\section{- Uranotaenia (Uranotaenia) albocephala da Cunha Ramos \& Brunhes, 2004 [51] \\ da Cunha Ramos \& Brunhes, 2004 [51]}

Endemic. Eggs and adult male remain to be described. Belongs to section and group Anopheloides. Larval habitats are tree holes with water containing organic matter. Collected only once and known only from the type locality (Masoala peninsula, in the eastern domain) [51].

\section{- Uranotaenia (Uranotaenia) andavakae Doucet, 1950 [65]}

Doucet, 1950 [65]

Endemic to Madagascar and the Comoros archipelago (Mayotte) [65]. Eggs undescribed. Belongs to section Anopheloides (Neireti Group). Larval habitats are cool and clear waters such as fountains, ditches with sphagnum, puddles, flooded meadows, rice fields, forest ponds, rock holes, and trickle of water along a stream [51, 65]. Occurs in the eastern domain, in mountainous areas of the western, eastern, and central domains [51], and can reach about $1800 \mathrm{~m}$ asl.

\section{- Uranotaenia (Uranotaenia) anopheloides Brunhes \& Razafindrasolo, 1975 [31]}

Brunhes \& Razafindrasolo, 1975 [31]

Endemic to Madagascar and to the Comoros archipelago (Mayotte) [31]. Eggs undescribed. Belongs to section Anopheloides. Larval stages are characterized by their bodies floating parallel to the surface of the water like those of Anopheles. Larval habitats are tree holes (mango tree, kapok tree, and Ravenala) [51]. Occurs in the western, central, and eastern domains, seems more abundant in the warmer regions of the western domain. Eggs are resistant to desiccation [51].

\section{- Uranotaenia (Uranotaenia) argentipleura da Cunha Ramos \& Brunhes, 2004 [51]}

da Cunha Ramos \& Brunhes, 2004 [51]

Endemic. Egg, larval and pupal stages undescribed. Belongs to section Caeruleocephala (Madagascarica Group). Larval habitats are grassy marshes. Occurs in the Sambirano area (Nosy Be) and the dry regions of the western and southern domains.

\section{- Uranotaenia (Uranotaenia) balfouri Theobald, 1904}

Doucet, 1949 [63]

Eggs undescribed. Belongs to section Alba (Balfouri Group). Morphologically close to Uranotaenia hebrardi. In Madagascar, larval habitats are canals containing iron hydroxide, rice fields, pools, marshes [63], grassy holes [103], muddy water under forest cover, swamps, and ponds [51]. Occurs in the Sambirano area (Nosy Be), in the western, eastern, and central domains. This species is found in Madagascar from sea level up to $1700 \mathrm{~m}$ asl [51]. Adult biology unknown. In Africa, feeds mainly on amphibians and cattle in Kenya [13].

\section{- Uranotaenia (Uranotaenia) bidentata da Cunha Ramos \& Brunhes, 2004 [51]}

da Cunha Ramos \& Brunhes, 2004 [51]

Endemic. Eggs, pupal and adult stages undescribed. Belongs to section Chorleyi (Hamoni Group). Biology unknown. Occurs in the Manambolosy area of Toamasina province and in the Ampatsinakoho area of Fianarantsoa province. Seems to be widely distributed throughout the eastern domain (from the Vangaindrano region to the Mananara region) at lower altitudes.

\section{- Uranotaenia (Uranotaenia) connali Edwards, 1912} [73]

da Cunha Ramos \& Brunhes, 2004 [51]

Eggs, larval and pupal stages undescribed. Belongs to section Alba (Bilineata Group). Biology unknown. In Madagascar, captured once and occurs on the Masoala peninsula in the eastern domain [51]. 


\section{- Uranotaenia (Uranotaenia) dumonti Doucet, 1949 [64] Doucet, 1949 [64] \\ Endemic. Only the larval stages were described [64]. Belongs} to section and group Dumonti. Larval habitats are water holes and reed beds. Collected only once and known only from the type locality (Ambohiby mountain stream, at $1633 \mathrm{~m}$ asl, in the Tsiroanomandidy region of the central domain) [51, 64].

\section{- Uranotaenia (Uranotaenia) geniculata da Cunha Ramos \& Brunhes, 2004 [51] \\ da Cunha Ramos \& Brunhes, 2004 [51]}

Endemic. Eggs undescribed. Belongs to section Caeruleocephala (Madagascarica Group). Larval habitats are tree holes containing clear water and cut bamboo. Occurs only on the Masoala peninsula in the eastern domain [51].

\section{- Uranotaenia (Uranotaenia) grassei da Cunha Ramos \& Brunhes, 2004 [51] \\ da Cunha Ramos \& Brunhes, 2004 [51]}

Endemic. Eggs and adult male undescribed. Belongs to section and group Dumonti. Larval habitats are streams of the relict primary rainforest and in holes containing clean and cool water. Occurs in the eastern domain [51].

\section{- Uranotaenia (Uranotaenia) hamoni Grjebine, 1953 [103]} Grjebine, 1953 [103]

Endemic. Eggs undescribed. Originally described under the name of Uranotaenia chorleyi var. hamoni [103] and formally elevated to species rank by White [238]. Belongs to section Chorleyi (Hamoni Group). Larval habitats are forest ponds, rivers, holes containing clear and fresh water, rice fields surrounded by forest, and forest streams. Occurs in the central, eastern, and western domains and was mainly caught in mountainous areas, above $800 \mathrm{~m}$ asl [51].

\section{- Uranotaenia (Uranotaenia) hebrardi da Cunha Ramos} \& Brunhes, 2004 [51]

da Cunha Ramos \& Brunhes, 2004 [51]

Endemic. Belongs to section Alba. Morphologically close to Uranotaenia balfouri (Balfouri Group). Larval habitats are ponds, rice fields, and marshes. Occurs in the eastern, western, and central domains. Caught only as larvae and on five capture occasions in the Amborompotsy [191] and Manakara areas of Fianarantsoa province, the Marvoay area of Mahajanga province, and the Ambodimanga and Moramanga areas of Toamasina province [51]

\section{- Uranotaenia (Uranotaenia) joucouri da Cunha Ramos \& Brunhes, 2004 [51]}

da Cunha Ramos \& Brunhes, 2004 [51]

Endemic. Eggs, pupal and adult stages undescribed. Belongs to Alba section and Group. Larval habitats are unknown. Collected only once and known only from the type locality (Foulpointe, in the eastern domain) [51].

\footnotetext{
- Uranotaenia (Uranotaenia) lebiedi da Cunha Ramos \& Brunhes, 2004 [51]

da Cunha Ramos \& Brunhes, 2004 [51]
}

Endemic. Eggs, larval and pupal stages undescribed. Belongs to section and group Dumonti. Adult biology unknown. Occurs in the eastern domain, and was caught as adult stage, below $900 \mathrm{~m}$ altitude [51].

\section{- Uranotaenia (Uranotaenia) madagascarica da Cunha} Ramos \& Brunhes, 2004 [51]

da Cunha Ramos \& Brunhes, 2004 [51]

Endemic. Eggs undescribed. Belongs to section Caeruleocephala. Larval habitats are holes containing plant debris and iron hydroxide. Occurs in the Ampatsinakoho area (Fianaranstsoa province) and in forested areas of the eastern domain: Mandena forest (Taolagnaro), Masoala National Park (Antsiranana province), and Andasibe National Park (Toamasina province) [51].

\section{- Uranotaenia (Uranotaenia) mayottensis Brunhes, 1977} [25]

da Cunha Ramos \& Brunhes, 2004 [51]

Endemic to Madagascar and the Comoros archipelago (Mayotte). Eggs undescribed. Belongs to Dumonti section. Larval habitats are fresh water, rivers, small forest streams [51], slow-flowing water, rock holes, and water ponds [145]. Present in Madagascar and on Mayotte. Occurs in the eastern, western, and southern domains, in Malagasy National Parks (Masoala, Bemaraha, Andasibe, and Ranomafana parks) and was caught in the Isaka area of Toliara province [51].

\section{- Uranotaenia (Uranotaenia) moramangae da Cunha} Ramos \& Brunhes, 2004 [51]

da Cunha Ramos \& Brunhes, 2004 [51]

Endemic. Eggs undescribed. This species belongs to section Chorleyi (Hamoni Group). Larval habitats are forest puddles, streams containing sphagnum, fresh and acidic water, cattle hoof prints, ditches, and grassy swamps. Occurs in the central, eastern, and southern domains [51] and is distributed between $450 \mathrm{~m}$ (Beraketa, Toliary province) and $1800 \mathrm{~m}$ asl (Ankaratra massif).

- Uranotaenia (Uranotaenia) neireti Edwards, 1920 [75] Edwards, 1920 [75]

Endemic. Eggs undescribed. Belongs to Anopheloides section. Larval habitats are hoof prints, lakes, and swamps areas. Present in the central and eastern domains and always between 900 and $2000 \mathrm{~m}$ asl [51].

\section{- Uranotaenia (Uranotaenia) roberti da Cunha Ramos \& Brunhes, 2004 [51] \\ da Cunha Ramos \& Brunhes, 2004 [51] \\ Endemic. Eggs, pupal and adult stages undescribed. Belongs to Chorleyi section (Hamoni Group). Larval habitats are slow-flowing water of small forest streams of primary rain- forest. Collected only once and known only from the type local- ity (Lakato area, above $1000 \mathrm{~m}$ asl of the eastern domain) [51].}

\section{Discussion}

The main remarkable characteristic of Malagasy mosquito fauna is the high biodiversity with 138 (of 235) endemic 
Table 1. Distribution of restricted endemic species for each Malagasy bioclimatic domain.

\begin{tabular}{|c|c|c|c|c|c|c|c|c|c|c|}
\hline & $\begin{array}{c}\text { Endemic } \\
\text { East }\end{array}$ & $\begin{array}{c}\text { Endemic } \\
\text { West }\end{array}$ & $\begin{array}{c}\text { Endemic } \\
\text { Sambirano }\end{array}$ & $\begin{array}{c}\text { Endemic } \\
\text { North }\end{array}$ & $\begin{array}{l}\text { Endemic } \\
\text { South }\end{array}$ & $\begin{array}{c}\text { Endemic } \\
\text { Centre }\end{array}$ & $\begin{array}{l}\text { Endemic } \\
\text { Mountain }\end{array}$ & $\begin{array}{c}\text { Endemic } \\
\text { Madagascar }^{\dagger}\end{array}$ & $\begin{array}{c}\text { Endemic Madagascar } \\
\text { and Comoros }\end{array}$ & $\begin{array}{c}\text { Number of } \\
\text { species }^{\#}\end{array}$ \\
\hline Aedeomyia & 1 & 0 & 0 & 0 & 0 & 0 & 0 & 2 & 0 & 3 \\
\hline Aedes & 7 & 0 & 0 & 1 & 0 & 0 & 0 & 18 & 2 & 35 \\
\hline Anopheles & 2 & 0 & 0 & 0 & 0 & 1 & 1 & 11 & 1 & 26 \\
\hline Coquillettidia & 0 & 0 & 0 & 0 & 0 & 0 & 0 & 2 & 0 & 3 \\
\hline Culex & 3 & 0 & 0 & 0 & 0 & 4 & 0 & 9 & 3 & $50 *$ \\
\hline Eretmapodites & 0 & 0 & 0 & 0 & 0 & 0 & 0 & 0 & 0 & 4 \\
\hline Ficalbia & 0 & 0 & 0 & 0 & 0 & 0 & 0 & 0 & 0 & 2 \\
\hline Hodgesia & $?$ & 0 & 0 & 0 & 0 & 0 & 0 & $?$ & 0 & $\geq 1$ \\
\hline Lutzia & 0 & 0 & 0 & 0 & 0 & 0 & 0 & 0 & 0 & 1 \\
\hline Mansonia & 0 & 0 & 0 & 0 & 0 & 0 & 0 & 0 & 0 & 2 \\
\hline Mimomyia & 12 & 0 & 1 & 0 & 0 & 2 & 0 & 17 & 0 & 22 \\
\hline Orthopodomyia & 3 & 0 & 0 & 1 & 0 & 1 & 1 & 8 & 0 & 8 \\
\hline Toxorhynchites & 6 & 0 & 0 & 0 & 0 & 0 & 0 & 6 & 0 & 6 \\
\hline Uranotaenia & 42 & 1 & 0 & 0 & 0 & 2 & 2 & 65 & 4 & 73 \\
\hline Total & 76 & 1 & 1 & 2 & 0 & 10 & $4 * *$ & 138 & 10 & 235 \\
\hline
\end{tabular}

$\dagger$ Endemic mosquitoes restricted to Madagascar.

$\S$ Endemic mosquitoes in Madagascar and the Comoros archipelago.

\# Species described and/or clearly identified.

* The species Culex thalassius, mentioned with doubt in Madagascar by Knight and Stone [132] and listed in Madagascar by the site WRBU (www.mosquitocatalog.org/, August 2014) [244], has not been recorded in this table; similarly the species belonging to the Rima group surveyed but remaining unidentified by Rhodain et al. [195] have not been recorded. Cx. pipiens and Cx. quinquefasciatus were counted as two separate species following the conclusion of Harbach [118].

${ }^{* *}$ The four species of mosquitoes known only in mountains areas (altitude $>1500 \mathrm{~m}$.) are usually associated with the central bioclimatic domain.

species $(58.7 \%)$. This pattern is not only specific to mosquitoes since Madagascar has one of the highest rates of endemicity in the world, due to its insularity with long geographic isolation since the migration of the Indo-Malagasy subcontinent $155-120$ million years ago. The isolation of the island dates from the Upper Cretaceous (83 million years). Paulian [173] highlighted this endemism rate in many vertebrate and invertebrate groups. The endemism rate is about $92-100 \%$ for terrestrial animals and $52-60 \%$ for flying animals (bats and birds) [100]. As an example, 75\% (97/130) of Drosophila species [135], all of the 40 species of scorpions [149], and 91\% (379/418) of ant species [84] are endemic to Madagascar.

Among other hematophagous arthropods other than mosquitoes, the endemism rate is $92 \%(11 / 12)$ in sand flies (Vincent Robert, pers. comm.), 78.2\% (36/46 species) in fleas (Sébastien Boyer, unpublished observation), and 79\% (27/34) in ticks [226].

\subsection{Diversity}

In total 235 mosquitoes species are currently recorded in Madagascar. These 235 species belong to 14 genera: Aedeomyia (3 species), Aedes (35 species), Anopheles (26 species), Coquillettida (3 species), Culex (at least 50 species), Eretmapodites (4 species), Ficalbia (2 species), Hodgesia (at least one species), Lutzia (one species), Mansonia (2 species), Mimomyia (22 species), Orthopodomyia (8 species), Toxorhynchites (6 species), and Uranotaenia (73 species). This number of 235 species is considerably higher than that given in the previous checklist published in 2003 (i.e. 178 species) [70] (Tables 1 and 2). This main difference is primarily due to the inclusion of an additional collection of Uranotaenia [14, 51], Toxorhynchites [190], Aedeomyia [33], and Aedes belonging to the subgenus Neomelaniconion [143]. However, this number is moderately lower than that given in Internet references such as WRBU (253 species) [244] and Arim (245 species) [5], which include an enlarged area of several islands in the Mozambique Channel.

The report of the genus Culiseta (Culiseta longiareolata (Macquart)) as present in Madagascar in the Arim dataset [5] is doubtful as information on collection areas is not available. To date, there is no conclusive evidence of the presence of this tropical species in Madagascar and this information was treated as an error.

Taking into account that 3546 mosquito species are currently recognized in the world [119], $6.6 \%$ of them are present in Madagascar. In addition, 28\% of the 804 known species in the Ethiopian zoogeographical area are present in Madagascar [144]. Moreover, despite decades of research, there is no doubt that new species remain to be discovered and that endemism could be higher than $60 \%$. Indeed, some species have been reported only once (32 endemic species) and sometimes described from a single specimen with the possibility of misidentification (7 endemic species). In addition, species complexes exist, and several new species could occur without having been identified and described. On the other hand, due to deforestation, anthropogenization, and degradation of natural (and poorly explored) biotopes, several mosquito species have probably already disappeared. 
Table 2. Summary information on the 235 mosquito species that occur in Madagascar.

\begin{tabular}{|c|c|c|c|c|c|c|c|c|}
\hline \multirow[b]{2}{*}{ Genus } & \multirow[b]{2}{*}{ Species } & \multirow[b]{2}{*}{$\begin{array}{l}\text { Unknown } \\
\text { stages }\end{array}$} & \multicolumn{4}{|c|}{ Biology of each species on Madagascar } & \multicolumn{2}{|l|}{$\begin{array}{c}\text { Pathogens associated with } \\
\text { each species }\end{array}$} \\
\hline & & & Endemicity & $\begin{array}{l}\text { Specific climatic } \\
\text { domain }\end{array}$ & $\begin{array}{l}\text { Host } \\
\text { preferences }\end{array}$ & $\begin{array}{l}\text { Larval } \\
\text { habitats }\end{array}$ & Madagascar & Africa \\
\hline Anopheles & coustani & & & & $\mathrm{GF}$ & $\mathrm{A}, \mathrm{N}$ & $\mathrm{BABV}^{£}$, PERV, RVFV, WNV, F & \\
\hline Anopheles & fuscicolor & & $\mathrm{X}$ & & & $\mathrm{A}, \mathrm{N}$ & $\mathrm{BABV}^{£}, \mathrm{PERV}^{£}, \mathrm{RVFV}^{£}, \mathrm{~F}$ & \\
\hline Anopheles & tenebrosus & & & $\mathrm{O}, \mathrm{N}, \mathrm{C}, \mathrm{W}$ & & $\mathrm{A}, \mathrm{N}$ & & $\mathrm{P}$ \\
\hline Anopheles & arabiensis & & & & GF & & & \\
\hline Anopheles & brunnipes & & & $\mathrm{W}, \mathrm{E}$ & & $\mathrm{A}, \mathrm{N}$ & WNV & \\
\hline Anopheles & cydippis & & & & & $\mathrm{T}, \mathrm{A}, \mathrm{N}$ & & \\
\hline Anopheles & flavicosta & & & & & $\mathrm{A}, \mathrm{N}$ & & $\mathrm{V}, \mathrm{F}, \mathrm{P}$ \\
\hline Anopheles & funestus & & & & & $\mathrm{A}, \mathrm{N}$ & & $\mathrm{V}$ \\
\hline Anopheles & gambiae & & & & GF & & & \\
\hline Anopheles & grassei & & $\mathrm{X}$ & $\mathrm{W}, \mathrm{S}$ & & $\mathrm{N}$ & $\mathrm{P}$ & \\
\hline Anopheles & grenieri & F M & $\mathrm{X}$ & $\mathrm{E}$ & & $\mathrm{A}, \mathrm{N}$ & & \\
\hline Anopheles & griveaudi & M L & $X$ & $\mathrm{C}$ & & & & \\
\hline Anopheles & lacani & $\mathrm{M}$ & $X$ & $\mathrm{C}, \mathrm{E}$ & & $\mathrm{N}$ & & \\
\hline Anopheles & maculipalpis & & & & GF & $\mathrm{A}, \mathrm{N}$ & WNV & $\mathrm{F}, \mathrm{P}^{*}$ \\
\hline Anopheles & mascarensis & & $\mathrm{X}^{\circ}$ & & GF & $\mathrm{A}, \mathrm{N}$ & NGAV, F, P & \\
\hline Anopheles & merus & & & $\mathrm{W}, \mathrm{S}$ & & $\mathrm{N}$ & $\mathrm{P}$ & \\
\hline Anopheles & milloti & & $\mathrm{X}$ & & & $\mathrm{N}$ & & \\
\hline Anopheles & notleyi & & $X$ & $\mathrm{~N}, \mathrm{E}$ & & $\mathrm{N}$ & & \\
\hline Anopheles & pauliani & & $\mathrm{X}$ & & GF & $\mathrm{A}, \mathrm{N}$ & $\mathrm{RVFV}^{£}, \mathrm{WNV}, \mathrm{F}$ & \\
\hline Anopheles & pharoensis & & & & & $A, N$ & & $\mathrm{~V}, \mathrm{~F}, \mathrm{P}^{*}$ \\
\hline Anopheles & pretoriensis & & & & GF & $\mathrm{A}, \mathrm{N}$ & & $\mathrm{V}, \mathrm{P}^{*}$ \\
\hline Anopheles & radama & & $\mathrm{X}$ & $\mathrm{O}, \mathrm{N}, \mathrm{W}, \mathrm{E}$ & & $\mathrm{N}$ & & \\
\hline Anopheles & ranci & & $\mathrm{X}$ & $\mathrm{N}, \mathrm{E}$ & & $\mathrm{A}, \mathrm{N}$ & & \\
\hline Anopheles & roubaudi & & $X$ & E & & $\mathrm{N}$ & & \\
\hline Anopheles & rufipes & & & & GF & $\mathrm{A}, \mathrm{N}$ & & $\mathrm{V}, \mathrm{P}^{\circ}$ \\
\hline Anopheles & squamosus & & & & $\mathrm{Z}$ & $\mathrm{A}, \mathrm{N}$ & ANDV, BTV, RVFV, F & $\mathrm{V}$ \\
\hline Aedeomyia & madagascarica & F M & $X$ & $\mathrm{E}, \mathrm{W}$ & $\mathrm{O}$ & & WNV & \\
\hline Aedeomyia & pauliani & $\mathrm{L}$ & $\mathrm{X}$ & E & & $\mathrm{P}$ & & \\
\hline Aedeomyia & furfurea & & & $\mathrm{E}, \mathrm{C}, \mathrm{W}$ & & $\mathrm{P}$ & & \\
\hline Aedes & albocephalus & & & $\mathrm{O}, \mathrm{N}, \mathrm{W}, \mathrm{S}, \mathrm{E}$ & GF & $\mathrm{N}$ & & \\
\hline Aedes & albodorsalis & M L & $X$ & $\mathrm{~W}, \mathrm{E}$ & $\mathrm{A}$ & & & \\
\hline Aedes & argenteopunctatus & & & $\mathrm{E}, \mathrm{C}$ & $\mathrm{A}$ & $\mathrm{N}$ & DBV & $\mathrm{V}, \mathrm{Nem}$ \\
\hline Aedes & dalzieli & & & $\mathrm{W}, \mathrm{S}$ & & $\mathrm{N}$ & & $\mathrm{V}, \mathrm{Nem}$ \\
\hline Aedes & domesticus & & & E & & $\mathrm{N}$ & & $\mathrm{V}$ \\
\hline Aedes & durbanensis & & & $\mathrm{S}, \mathrm{W}$ & & $\mathrm{N}$ & & $\mathrm{V}$ \\
\hline Aedes & fowleri & & & $\mathrm{W}, \mathrm{S}, \mathrm{E}, \mathrm{C}$ & & $\mathrm{A}, \mathrm{N}$ & & V, Set \\
\hline Aedes & masoalensis & M L & $X$ & $\mathrm{E}$ & A & & $\mathrm{MgV}$ & \\
\hline Aedes & mathioti & M L & $X$ & $\mathrm{E}$ & A & & & \\
\hline Aedes & natronius & & & $\mathrm{S}$ & & & & $\mathrm{V}$ \\
\hline Aedes & fryeri & & & W, S & A & $\mathrm{N}$ & & $\mathrm{V}^{£}$ \\
\hline Aedes & coulangesi & $\mathrm{L}$ & $\mathrm{X}$ & $\mathrm{W}, \mathrm{N}, \mathrm{S}$ & A & & & \\
\hline Aedes & grassei & $\mathrm{L}$ & $\mathrm{X}$ & E & & & & \\
\hline Aedes & madagascarensis & $\mathrm{L}$ & $\mathrm{X}$ & $\mathrm{O}, \mathrm{N}, \mathrm{W}, \mathrm{C}, \mathrm{E}$ & A & & WNV & \\
\hline Aedes & sylvaticus & F L & $X$ & $\mathrm{E}$ & & & & \\
\hline Aedes & tiptoni & & $\mathrm{X}$ & & A & $\mathrm{P}$ & & \\
\hline Aedes & vittatus & & & $\mathrm{O}, \mathrm{W}, \mathrm{C}, \mathrm{E}, \mathrm{S}$ & A & $\mathrm{A}, \mathrm{N}$ & & $\mathrm{V}$ \\
\hline Aedes & scatophagoides & & S & & $\mathrm{N}$ & & & \\
\hline Aedes & mucidus & & & E & & & & \\
\hline Aedes & albiradius & M L & $\mathrm{X}$ & $\mathrm{W}, \mathrm{C}, \mathrm{S}$ & & & & \\
\hline Aedes & belleci & & $X$ & E & & $\mathrm{N}$ & & \\
\hline Aedes & circumluteolus & & & $\mathrm{W}, \mathrm{E}, \mathrm{C}$ & A & $\mathrm{N}$ & WNV & $\mathrm{V}$ \\
\hline Aedes & fontenillei & $\mathrm{L}$ & $\mathrm{X}$ & E & & $\mathrm{N}$ & & \\
\hline Aedes & nigropterum & $\mathrm{L}$ & $\mathrm{X}$ & $\mathrm{E}$ & & & & \\
\hline Aedes & sylvaticum & $\mathrm{L}$ & $\mathrm{X}$ & $\mathrm{N}, \mathrm{E}$ & & & & \\
\hline Aedes & ambreensis & M L & $\mathrm{X}$ & $\mathrm{N}$ & A & & MMP 158 Virus & \\
\hline Aedes & cartroni & $\mathrm{L}$ & $\mathrm{X}^{\circ}$ & $\mathrm{W}, \mathrm{S}, \mathrm{N}, \mathrm{E}$ & A & $\mathrm{N}$ & $\mathrm{MgV}$ & \\
\hline
\end{tabular}


Table 2. (continued)

\begin{tabular}{|c|c|c|c|c|c|c|c|c|}
\hline \multirow[b]{2}{*}{ Genus } & \multirow[b]{2}{*}{ Species } & \multirow[b]{2}{*}{$\begin{array}{l}\text { Unknown } \\
\text { stages }\end{array}$} & \multicolumn{4}{|c|}{ Biology of each species on Madagascar } & \multicolumn{2}{|c|}{$\begin{array}{c}\text { Pathogens associated with } \\
\text { each species }\end{array}$} \\
\hline & & & Endemicity & $\begin{array}{l}\text { Specific climatic } \\
\text { domain }\end{array}$ & $\begin{array}{c}\text { Host } \\
\text { preferences }\end{array}$ & $\begin{array}{c}\text { Larval } \\
\text { habitats }\end{array}$ & Madagascar & Africa \\
\hline Aedes & lambrechti & & & $\mathrm{O}, \mathrm{N}$ & & $\mathrm{N}$ & & \\
\hline Aedes & moucheti & F L & $\mathrm{X}$ & $\mathrm{O}, \mathrm{W}, \mathrm{C}, \mathrm{E}, \mathrm{S}$ & & $\mathrm{N}$ & & \\
\hline Aedes & aegypti & & & & A & $\mathrm{T}, \mathrm{P}$ & $\begin{array}{l}\text { BABV, MMP 158, } \\
\text { WNV }\end{array}$ & $\mathrm{V}$ \\
\hline Aedes & albopictus & & & & A & $\mathrm{T}, \mathrm{P}$ & BABV & $\mathrm{V}$ \\
\hline Aedes & brygooi & & $\mathrm{X}$ & $\mathrm{O}, \mathrm{N}, \mathrm{W}, \mathrm{S}, \mathrm{C}$ & & $\mathrm{P}$ & & \\
\hline Aedes & interruptus & $\mathrm{L}$ & $\mathrm{X}$ & E, C & & $\mathrm{T}$ & & \\
\hline Aedes & monetus & & $\mathrm{X}^{\circ}$ & $\mathrm{N}, \mathrm{W}, \mathrm{S}, \mathrm{E}$ & & $\mathrm{P}$ & & \\
\hline Aedes & phillipi & & $\mathrm{X}$ & $\mathrm{O}, \mathrm{E}, \mathrm{W}, \mathrm{N}, \mathrm{C}$ & & $\mathrm{P}$ & & \\
\hline Coquillettidia & grandidieri & & $\mathrm{X}$ & $\mathrm{W}, \mathrm{E}, \mathrm{C}$ & GF & $\mathrm{N}$ & $\mathrm{RVFV}^{\mathfrak{f}}$ & \\
\hline Coquillettidia & metallica & & & $\mathrm{W}, \mathrm{E}, \mathrm{C}$ & A & & & $\mathrm{V}, \mathrm{P} \mu$ \\
\hline Coquillettidia & rochei & $\mathrm{L}$ & $X$ & W, E, C & A & & & \\
\hline Culex & antennatus & & & & GF & $\mathrm{A}, \mathrm{N}$ & & $\mathrm{V}, \mathrm{F}, \mathrm{P} \mu$ \\
\hline Culex & argenteopunctatus & & $\mathrm{X}$ & $\mathrm{C}, \mathrm{E}$ & & $\mathrm{N}$ & & \\
\hline Culex & carleti & & $\mathrm{X}^{\circ}$ & $\mathrm{O}, \mathrm{E}$ & A & $\mathrm{P}$ & & \\
\hline Culex & comorensis & & $\mathrm{X}^{\circ}$ & $\mathrm{C}, \mathrm{E}$ & & $\mathrm{P}, \mathrm{T}, \mathrm{N}$ & & \\
\hline Culex & decens & & & & GF & $\mathrm{P}, \mathrm{A}, \mathrm{N}$ & BABV, WNV & $\mathrm{V}$ \\
\hline Culex & demeilloni & M F & $X$ & $\mathrm{C}$ & & & & \\
\hline Culex & duttoni & & & $\mathrm{O}, \mathrm{C}$ & & $\mathrm{N}$ & & $\mathrm{V}$ \\
\hline Culex & grahamii & & & $\mathrm{C}$ & & & & \\
\hline Culex & guiarti & & & $\mathrm{E}$ & A & $\mathrm{N}$ & & $\mathrm{V}, \mathrm{P} \mu$ \\
\hline Culex & neavei & & & $\mathrm{C}$ & & & & $\mathrm{V}, \mathrm{P} \mu$ \\
\hline Culex & perfidiosus & & & $\mathrm{E}$ & & A, $N$ & & \\
\hline Culex & pipiens & & & $\mathrm{C}, \mathrm{W}$ & GF & $\mathrm{T}, \mathrm{A}$ & & $\mathrm{V}, \mathrm{P} \mu$ \\
\hline Culex & quasiguiarti & & & $\mathrm{C}, \mathrm{E}, \mathrm{S}$ & & & & \\
\hline Culex & quinquefasciatus & & & & GF & $\mathrm{T}$ & WN, BABV, PERV, F & $\mathrm{V}, \mathrm{P} \mu$ \\
\hline Culex & scottii & $\mathrm{L}$ & & $\mathrm{C}, \mathrm{E}$ & A & & WNV & \\
\hline Culex & simpsoni & & & $\mathrm{O}, \mathrm{E}$ & A & $\mathrm{T}, \mathrm{N}$ & $\mathrm{RVFV}^{£}$ & \\
\hline Culex & sitiens & & & $\mathrm{O}, \mathrm{W}, \mathrm{C}$ & & & & $\mathrm{V}$ \\
\hline Culex & striatipes & & & E, C & & $\mathrm{A}, \mathrm{N}$ & & \\
\hline Culex & theileri & & & E & & & & \\
\hline Culex & tritaeniorhynchus & & & & GF & A & MgV, WNV & $\mathrm{V}, \mathrm{P} \mu^{\S}$ \\
\hline Culex & perfuscus & & & $\mathrm{O}$ & & & & V \\
\hline Culex & trifilatus & $\mathrm{L}$ & & W & & & & \\
\hline Culex & univittatus & & & $\mathrm{W}, \mathrm{S}, \mathrm{E}, \mathrm{C}$ & $\mathrm{Z}$ & A & $\mathrm{BABV}^{£}, \mathrm{MgV}$ & $\mathrm{V}, \mathrm{F}, \mathrm{P} \mu$ \\
\hline Culex & ventrilloni & $\mathrm{L}$ & $X$ & $\mathrm{C}$ & & & & \\
\hline Culex & watti & & & $\mathrm{O}, \mathrm{E}$ & & $\mathrm{N}$ & & \\
\hline Culex & vansomereni & & & E & & & $\mathrm{BABV}^{£}, \mathrm{RVFV}^{£}$ & $\mathrm{~V}$ \\
\hline Culex & weschei & & & $\mathrm{C}$ & A & $\mathrm{N}$ & & $\mathrm{V}$ \\
\hline Culex & cinerellus & & & $\mathrm{O}, \mathrm{E}$ & & $\mathrm{P}$ & & \\
\hline Culex & cinereus & & & $\mathrm{O}, \mathrm{W}$ & & $\mathrm{P}$ & & $\mathrm{V}$ \\
\hline Culex & milloti & M F & $X$ & $\mathrm{C}$ & & $\mathrm{N}$ & & \\
\hline Culex & nebulosus & & & $\mathrm{O}, \mathrm{W}, \mathrm{E}, \mathrm{C}$ & A & $\mathrm{P}$ & & $\mathrm{V}$ \\
\hline Culex & pandani & & $\mathrm{X}$ & E & A & $\mathrm{P}$ & & \\
\hline Culex & subaequalis & $\mathrm{F}$ & & $?$ & & & & \\
\hline Culex & moucheti & & & $\mathrm{E}$ & & & & $\mathrm{V}$ \\
\hline Culex & brenguesi & & $\mathrm{X}$ & E & & $\mathrm{N}$ & & \\
\hline Culex & chauveti & & $\mathrm{X}^{\circ}$ & $\mathrm{E}, \mathrm{C}$ & A & $\mathrm{N}$ & & \\
\hline Culex & horridus & & & $\mathrm{W}, \mathrm{C}$ & & $\mathrm{P}$ & & \\
\hline Culex & insignis & & & $\mathrm{O}$ & & & & \\
\hline Culex & kingianus & & & $\mathrm{W}, \mathrm{E}$ & & $\mathrm{P}, \mathrm{N}$ & & \\
\hline Culex & rubinotus & & & $\mathrm{O}, \mathrm{E}$ & & $\mathrm{P}$ & & $\mathrm{V}$ \\
\hline Culex & sunyaniensis & & & E & & $\mathrm{P}, \mathrm{N}$ & & \\
\hline Culex & wigglesworthi & & & $\mathrm{E}$ & & & & \\
\hline Culex & salisburiensis/coursi & M F & $\mathrm{X}$ & $\mathrm{E}$ & & A & & \\
\hline Culex & $\begin{array}{l}\text { salisburiensis/ } \\
\quad \text { salisburiensis }\end{array}$ & & & $\mathrm{C}$ & & & & \\
\hline
\end{tabular}


Table 2. (continued)

\begin{tabular}{|c|c|c|c|c|c|c|c|c|}
\hline \multirow[b]{2}{*}{ Genus } & \multirow[b]{2}{*}{ Species } & \multirow[b]{2}{*}{$\begin{array}{l}\text { Unknown } \\
\text { stages }\end{array}$} & \multicolumn{4}{|c|}{ Biology of each species on Madagascar } & \multicolumn{2}{|c|}{$\begin{array}{l}\text { Pathogens associated with } \\
\text { each species }\end{array}$} \\
\hline & & & Endemicity & $\begin{array}{l}\text { Specific climatic } \\
\text { domain }\end{array}$ & $\begin{array}{c}\text { Host } \\
\text { preferences }\end{array}$ & $\begin{array}{c}\text { Larval } \\
\text { habitats }\end{array}$ & Madagascar & Africa \\
\hline Culex & seyrigi & & $\mathrm{X}$ & $\mathrm{C}$ & & $\mathrm{N}$ & & \\
\hline Culex & aurantapex & $\mathrm{M}$ & & E & A & & & \\
\hline Culex & annulioris & & & $\mathrm{E}, \mathrm{C}, \mathrm{S}$ & & & $\mathrm{RVFV}^{£}$ & \\
\hline Culex & bitaeniorhynchus & & $\mathrm{W}, \mathrm{E}, \mathrm{C}, \mathrm{S}$ & GF & $\mathrm{A}, \mathrm{N}$ & & $\mathrm{V}, \mathrm{P} \mu^{* \S}$ & \\
\hline Culex & giganteus & & X & $\mathrm{C}, \mathrm{E}, \mathrm{W}, \mathrm{S}$ & GF & $\mathrm{A}, \mathrm{N}$ & & \\
\hline Culex & poicilipes & & & W, C, E & GF & $\mathrm{A}, \mathrm{N}$ & & $\mathrm{V}, \mathrm{F}, \mathrm{P} \mu$ \\
\hline Eretmapodites & oedipodeios & $\mathrm{L}$ & & E & & & & V \\
\hline Eretmapodites & plioleucus & $\mathrm{L}$ & & $\mathrm{O}, \mathrm{E}$ & & & & \\
\hline Eretmapodites & quinquevittatus & & & A & $\mathrm{P}, \mathrm{N}$ & $\mathrm{MgV}$ & $\mathrm{V}$ & \\
\hline Eretmapodites & subsimplicipes & & & $\mathrm{E}$ & $\mathrm{A}^{\$}$ & & & $\mathrm{~V}$ \\
\hline Ficalbia & uniformis & & & $\mathrm{E}, \mathrm{C}$ & & $\mathrm{N}$ & & \\
\hline Ficalbia & circumtestacea & & & $\mathrm{E}, \mathrm{W}$ & & & & \\
\hline Hodgesia & Hodgesiasp & & & E & A & $\mathrm{N}$ & & \\
\hline Lutzia & tigripes & & & $\mathrm{O}, \mathrm{W}, \mathrm{E}, \mathrm{C}$ & & $\mathrm{T}, \mathrm{A}, \mathrm{N}$ & & $\mathrm{V}$ \\
\hline Mansonia & africana & & & W & $\mathrm{A}$ & & & $\mathrm{F}, \mathrm{V}$ \\
\hline Mansonia & uniformis & & & $\mathrm{W}, \mathrm{S}, \mathrm{E}, \mathrm{C}$ & GF & $\mathrm{A}, \mathrm{N}$ & $\begin{array}{l}\text { BABV, PERV, RVFV, } \\
\text { WNV, F }\end{array}$ & $\mathrm{V}, \mathrm{P} \mu$ \\
\hline Mimomyia & martinei & M L & $\mathrm{X}$ & $\mathrm{E}$ & & & & \\
\hline Mimomyia & mediolineata & & & $\mathrm{W}, \mathrm{E}$ & A & $\mathrm{N}$ & & \\
\hline Mimomyia & aurata & & $\mathrm{X}$ & $\mathrm{C}, \mathrm{E}$ & A & $\mathrm{P}$ & & \\
\hline Mimomyia & bernardi & & $\mathrm{X}$ & $\mathrm{E}$ & & $\mathrm{P}$ & & \\
\hline Mimomyia & beytouti & & $\mathrm{X}$ & $\mathrm{E}$ & & $\mathrm{P}$ & & \\
\hline Mimomyia & brygooi & $\mathrm{F}$ & $\mathrm{X}$ & $\mathrm{E}$ & & $\mathrm{P}$ & & \\
\hline Mimomyia & collessi & & $\mathrm{X}$ & $\mathrm{E}$ & & & & \\
\hline Mimomyia & jeansottei & & $\mathrm{X}$ & $\mathrm{E}$ & & $\mathrm{P}$ & & \\
\hline Mimomyia & levicastilloi & M F & $\mathrm{X}$ & $\mathrm{E}$ & & $\mathrm{P}$ & & \\
\hline Mimomyia & longicornis & & $\mathrm{X}$ & $\mathrm{E}$ & & $P$ & & \\
\hline Mimomyia & marksae & & $\mathrm{X}$ & $\mathrm{E}$ & & $\mathrm{P}$ & & \\
\hline Mimomyia & mattinglyi & $\mathrm{F}$ & $\mathrm{X}$ & E & & $\mathrm{P}$ & & \\
\hline Mimomyia & milloti & & $\mathrm{X}$ & $\mathrm{C}$ & & $\mathrm{P}$ & & \\
\hline Mimomyia & ramalai & M & $\mathrm{X}$ & $\mathrm{C}$ & & $\mathrm{P}$ & & \\
\hline Mimomyia & roubaudi & & $\mathrm{X}$ & $\mathrm{W}, \mathrm{E}$ & & $\mathrm{P}$ & & \\
\hline Mimomyia & spinosa & & $\mathrm{X}$ & E & & $\mathrm{P}$ & & \\
\hline Mimomyia & stellata & & $\mathrm{X}$ & $\mathrm{E}$ & & $P$ & & \\
\hline Mimomyia & vansomerenae & M F & $\mathrm{X}$ & $\mathrm{O}$ & & $\mathrm{P}$ & & \\
\hline Mimomyia & hispida & & & $\mathrm{C}$ & & $\mathrm{A}, \mathrm{N}$ & & \\
\hline Mimomyia & mimomyiaformis & & & $\mathrm{W}, \mathrm{E}$ & & $\mathrm{N}$ & & \\
\hline Mimomyia & plumosa & & & $\mathrm{O}, \mathrm{E}$ & & $\mathrm{N}$ & & \\
\hline Miтотуіа & splendens & & & $\mathrm{W}, \mathrm{E}$ & & $\mathrm{N}$ & & \\
\hline Orthopodomyia & ambremontis & $\mathrm{F}$ & $\mathrm{X}$ & $\mathrm{N}$ & & $\mathrm{P}$ & & \\
\hline Orthopodomyia & ankaratrensis & M F & $\mathrm{X}$ & $\mathrm{C}$ & & $\mathrm{P}$ & & \\
\hline Orthopodomyia & fontenillei & & $\mathrm{X}$ & $\mathrm{C}, \mathrm{E}$ & & $\mathrm{P}$ & & \\
\hline Orthopodomyia & milloti & & $\mathrm{X}$ & $\mathrm{C}, \mathrm{E}$ & & $\mathrm{P}$ & & \\
\hline Orthopodomyia & rajaonariveloi & M L & $\mathrm{X}$ & $\mathrm{E}$ & & & & \\
\hline Orthopodomyia & ravaonjanaharyi & & $\mathrm{X}$ & $\mathrm{N}$ & & $\mathrm{P}$ & & \\
\hline Orthopodomyia & rodhaini & $\mathrm{L}$ & $\mathrm{X}$ & E & & $\mathrm{P}$ & & \\
\hline Orthopodomyia & vernoni & & $\mathrm{X}$ & $\mathrm{W}, \mathrm{E}$ & & $\mathrm{P}, \mathrm{T}$ & & \\
\hline Toxorhynchites & brunhesi & & $X$ & E & & & & \\
\hline Toxorhynchites & fontenillei & F L & $\mathrm{X}$ & $\mathrm{E}$ & & $\mathrm{P}$ & & \\
\hline Toxorhynchites & grjebinei & & $\mathrm{X}$ & $\mathrm{E}$ & & $\mathrm{P}$ & & \\
\hline Toxorhynchites & lemuriae & M L & $\mathrm{X}$ & E & & $\mathrm{P}$ & & \\
\hline Toxorhynchites & madagascarensis & & $\mathrm{X}$ & $\mathrm{E}$ & & $\mathrm{P}$ & & \\
\hline Toxorhynchites & pauliani & M L & $\mathrm{X}$ & E & & $\mathrm{P}$ & & \\
\hline Uranotaenia & albimanus & $\mathrm{L}$ & $\mathrm{X}$ & E & & $\mathrm{P}$ & & \\
\hline Uranotaenia & albinotata & & $\mathrm{X}$ & $\mathrm{E}$ & & $\mathrm{P}$ & & \\
\hline Uranotaenia & ambodimanga & $\mathrm{L}$ & $\mathrm{X}$ & $\mathrm{E}$ & & $\mathrm{P}$ & & \\
\hline Uranotaenia & antalahaensis & M L & $X$ & E & & $\mathrm{P}$ & & \\
\hline
\end{tabular}


Table 2. (continued)

\begin{tabular}{|c|c|c|c|c|c|c|c|c|}
\hline \multirow[b]{2}{*}{ Genus } & \multirow[b]{2}{*}{ Species } & \multirow[b]{2}{*}{$\begin{array}{l}\text { Unknown } \\
\text { stages }\end{array}$} & \multicolumn{4}{|c|}{ Biology of each species on Madagascar } & \multicolumn{2}{|c|}{$\begin{array}{l}\text { Pathogens associated with } \\
\text { each species }\end{array}$} \\
\hline & & & Endemicity & $\begin{array}{c}\text { Specific climatic } \\
\text { domain }\end{array}$ & $\begin{array}{c}\text { Host } \\
\text { preferences }\end{array}$ & $\begin{array}{c}\text { Larval } \\
\text { habitats }\end{array}$ & Madagascar & Africa \\
\hline Uranotaenia & apicosquamata & $\mathrm{X}$ & $\mathrm{O}, \mathrm{W}, \mathrm{E}$ & & $\mathrm{P}, \mathrm{N}$ & & & \\
\hline Uranotaenia & bambusicola & M & $\mathrm{X}$ & $\mathrm{E}$ & & $\mathrm{P}$ & & \\
\hline Uranotaenia & belkini & & $X$ & $\mathrm{E}$ & & $\mathrm{P}$ & & \\
\hline Uranotaenia & bicincta & $\mathrm{F}$ & $X$ & $\mathrm{O}, \mathrm{E}$ & & $\mathrm{P}$ & & \\
\hline Uranotaenia & bifasciata & M & $\mathrm{X}$ & $\mathrm{E}$ & & $\mathrm{N}$ & & \\
\hline Uranotaenia & bosseri & & $\mathrm{X}$ & E & & $\mathrm{P}$ & & \\
\hline Uranotaenia & boussesi & M F & $\mathrm{X}$ & E & & $\mathrm{P}$ & & \\
\hline Uranotaenia & breviseta & F L & $\mathrm{X}$ & $\mathrm{E}$ & & $\mathrm{P}$ & & \\
\hline Uranotaenia & brumpti & & $\mathrm{X}$ & $\mathrm{E}$ & & $\mathrm{P}, \mathrm{N}$ & & \\
\hline Uranotaenia & brunhesi & & $\mathrm{X}$ & $\mathrm{E}$ & & $\mathrm{P}$ & & \\
\hline Uranotaenia & cachani & & $\mathrm{X}$ & $\mathrm{C}, \mathrm{E}$ & & $\mathrm{P}$ & & \\
\hline Uranotaenia & carcinicola & & $X$ & E & & $\mathrm{N}$ & & \\
\hline Uranotaenia & combesi & & $X$ & $\mathrm{~W}, \mathrm{E}, \mathrm{C}, \mathrm{S}$ & & $\mathrm{T}, \mathrm{P}, \mathrm{N}$ & & \\
\hline Uranotaenia & contrastata & M L & $X$ & E & & $\mathrm{P}$ & & \\
\hline Uranotaenia & cornuta & $\mathrm{M}$ & $X$ & E & & $\mathrm{P}$ & & \\
\hline Uranotaenia & damasei & M F & $X$ & E & & $\mathrm{P}$ & & \\
\hline Uranotaenia & donai & M F & $X$ & E & & $\mathrm{P}$ & & \\
\hline Uranotaenia & douceti & & $X$ & $\mathrm{O}, \mathrm{W}, \mathrm{E}$ & & $\mathrm{P}$ & & \\
\hline Uranotaenia & fulgens & $\mathrm{M}$ & $X$ & E & & $\mathrm{P}$ & & \\
\hline Uranotaenia & grenieri & & $X$ & $\mathrm{C}, \mathrm{E}$ & & $\mathrm{P}, \mathrm{N}$ & & \\
\hline Uranotaenia & grjebinei & & $X$ & E & & $\mathrm{P}$ & & \\
\hline Uranotaenia & haddowi & & $X$ & $\mathrm{O}, \mathrm{N}, \mathrm{W}, \mathrm{E}$ & & $\mathrm{P}$ & & \\
\hline Uranotaenia & hervyi & & $\mathrm{X}$ & E & & $\mathrm{P}$ & & \\
\hline Uranotaenia & hirsuta & M F & $X$ & W & & $\mathrm{N}$ & & \\
\hline Uranotaenia & kraussi & & $\mathrm{X}$ & $\mathrm{N}, \mathrm{C}$ & & $\mathrm{P}$ & & \\
\hline Uranotaenia & laffosseae & & $\mathrm{X}^{\circ}$ & $\mathrm{N}, \mathrm{E}$ & & $\mathrm{P}$ & & \\
\hline Uranotaenia & lavieri & M F & $\mathrm{X}$ & $\mathrm{O}, \mathrm{N}, \mathrm{E}$ & & $\mathrm{P}$ & & \\
\hline Uranotaenia & legoffi & & $\mathrm{X}$ & E & & $\mathrm{P}$ & & \\
\hline Uranotaenia & longitubus & M F & $X$ & E & & $\mathrm{P}$ & & \\
\hline Uranotaenia & lousthei & M F & $\mathrm{X}$ & E & & $\mathrm{P}$ & & \\
\hline Uranotaenia & madagascarensis & & $\mathrm{X}$ & $\mathrm{E}$ & & $\mathrm{P}$ & & \\
\hline Uranotaenia & manakaraensis & $\mathrm{L}$ & $\mathrm{X}$ & $\mathrm{E}$ & & $\mathrm{P}$ & & \\
\hline Uranotaenia & nigricephala & & $X$ & E & & $\mathrm{P}$ & & \\
\hline Uranotaenia & nigripleura & $\mathrm{L}$ & $\mathrm{X}$ & $\mathrm{E}$ & & $\mathrm{P}$ & & \\
\hline Uranotaenia & pallidipleura & $\mathrm{L}$ & $\mathrm{X}$ & $\mathrm{E}$ & & $\mathrm{P}$ & & \\
\hline Uranotaenia & pauliani & M F & $\mathrm{X}$ & $\mathrm{C}$ & & $\mathrm{P}$ & & \\
\hline Uranotaenia & pilosa & $\mathrm{F}$ & $\mathrm{X}$ & $\mathrm{C}, \mathrm{E}$ & & $\mathrm{P}$ & & \\
\hline Uranotaenia & pseudoalbimanus & & $\mathrm{X}$ & $\mathrm{E}$ & & $\mathrm{P}$ & & \\
\hline Uranotaenia & pseudoshillitonis & & $\mathrm{X}$ & $\mathrm{C}, \mathrm{E}$ & & $\mathrm{P}$ & & \\
\hline Uranotaenia & ravenalaphila & M F & $\mathrm{X}$ & $\mathrm{E}$ & & $\mathrm{P}$ & & \\
\hline Uranotaenia & ravenalicola & & $X$ & E & & $\mathrm{P}$ & & \\
\hline Uranotaenia & scutostriata & & $\mathrm{X}$ & E & & $\mathrm{P}$ & & \\
\hline Uranotaenia & spinitubus & M F & $\mathrm{X}$ & $\mathrm{E}$ & & $\mathrm{P}$ & & \\
\hline Uranotaenia & spinosa & M & $X$ & $\mathrm{E}$ & & $\mathrm{P}$ & & \\
\hline Uranotaenia & spiraculata & & $\mathrm{X}$ & E & & $\mathrm{P}$ & & \\
\hline Uranotaenia & tricolor & M F & $\mathrm{X}$ & $\mathrm{E}$ & & $\mathrm{P}$ & & \\
\hline Uranotaenia & tridentata & M F & $X$ & $\mathrm{E}$ & & $\mathrm{P}$ & & \\
\hline Uranotaenia & tsaratananae & & $\mathrm{X}$ & $\mathrm{N}, \mathrm{E}$ & & $\mathrm{P}$ & & \\
\hline Uranotaenia & alba & & & $\mathrm{E}$ & & $\mathrm{A}$ & & \\
\hline Uranotaenia & alboabdominalis & & & W, E & & $\mathrm{N}$ & & \\
\hline Uranotaenia & albocephala & M & $\mathrm{X}$ & E & & $\mathrm{P}$ & & \\
\hline Uranotaenia & andavakae & & $\mathrm{X}^{\circ}$ & $\mathrm{W}, \mathrm{C}, \mathrm{E}$ & & $\mathrm{A}, \mathrm{N}$ & & \\
\hline Uranotaenia & anopheloides & & $X^{\circ}$ & $\mathrm{W}, \mathrm{C}, \mathrm{E}$ & & $\mathrm{P}$ & & \\
\hline Uranotaenia & argentipleura & $\mathrm{L}$ & $\mathrm{X}$ & $\mathrm{O}, \mathrm{W}, \mathrm{S}$ & & $\mathrm{N}$ & & \\
\hline Uranotaenia & balfouri & & & $\mathrm{O}, \mathrm{W}, \mathrm{C}, \mathrm{E}$ & & $\mathrm{A}, \mathrm{N}$ & & \\
\hline
\end{tabular}


Table 2. (continued)

\begin{tabular}{llccccc}
\hline & & \multicolumn{3}{c}{ Biology of each species on Madagascar } & Pathogens associated with \\
each species
\end{tabular}

M: male, F: female, L: larva (only the information about the stages of development routinely used in taxonomy are indicated: adult and larva). ${ }^{\circ}$ Endemic in Madagascar and Comoros archipelagos specific bioclimatic domains, W: west, C: center, E: east, N: north, S: south, O: Sambirano (in case of presence in all climatic domains the response remained blank).

?The locality where this species was collected was not well specified.

O: ornitophile, Z: zoophile, (ruminants), A: anthropophilic, GF: general feeder (Z, O, A). A: terrestrial water accumulation associated with agricultural activity, $\mathrm{N}$ : natural larval habitats associated with terrestrial habitat, P: phytotelmata (bamboo, tree hole, leaf axils), T: artificial containers (small plastic receptacles, tires, drums, cans, sewage) water accumulation (temporary or not). F: filariasis, PERV: Périnet virus, RVFV: Rift Valley fever virus, WNV: West Nile virus, BABV: Babanki virus, P: Plasmodium parasite, NGAV: Ngari virus, ANDV: Andasibe virus, DBV: Dakar Bat virus, BTV: Bluetongue virus, MgV: Mengo virus.

${ }^{£}$ mixed batch of mosquito species.

$\mathrm{V}$ : virus (arbovirus or not).

* Presence of at least an oocyst stage of Plasmodium. $\mu=$ avian plasmodium.

$\$$ On Comoros island.

$\S$ In Japan.

\subsection{Endemism rate of Malagasy mosquitoes}

Mosquitoes already existed before separation of Madagascar and the Indian subcontinent from Africa, 156 million years ago, during the Upper Jurassic. The phylogeographic origins of sylvatic Malagasy mosquito species are not easy to decipher, and we do not yet know when and how founder species reached Madagascar. Differentiation occurred in nearly all the country's biogeographic domains. It was not observed in the southern domain because no strictly southern endemic species is known. However, there are Malagasy endemic mosquitoes in all biogeographic domains, including the south where more than $33 \%$ of species are endemic. The eastern domain, where the relict rainforest is still present, has the highest number of mosquito species $(n=190)$ and level of regional endemism (67\%). Several species are microendemics, only present (or described) in a single biotope, often in forested areas (e.g., Ae. ambreensis, Ae albodorsalis, Ae. mathioti, An. roubaudi, Mi. longicornis, Mi. mattinglyi, Mi. stellata, and Or. ankaratrensis, all species belonging to the genus Toxorhynchites, and eight species belonging to the genus Uranotaenia).

There is no endemic genus in Madagascar. Mosquito species endemism occurs in 9 of the 13 genera of mosquito, with variation of the endemism rate from $27 \%$ to $100 \%$, according to the genus.
The genus Aedeomyia has 66\% (2/3) endemism. This genus is distributed in the Australasian, Oriental, African, and Neotropical regions [117]. The known species would appear to be from a primitive population that developed during the fragmentation of Gondwana 100 million years ago [33].

The genus Aedes (which includes the following subgenera, or genera in the new classification: Aedimorphus, Coetzeemyia, Diceromyia, Fredwardsius, Mucidus, Neomelaniconion, Ochlerotatus, Skusea, Stegomyia, and Zavortinkius) has 57\% (20/ 35) endemism. This genus of Malagasy fauna has a higher affinity with those of the African continent, Indonesian region [182], and Oriental region [193].

The genus Anopheles has a cosmopolitan distribution [117]. All non-endemic Anopheles species are known from broad regions of Africa. The Anopheles fauna of Madagascar is typically Ethiopian and the occurrence of high endemism $(46 \% ; 12 / 26)$ supports evidence that its separation from the mainland must have taken place a long time ago [70].

The genus Coquillettidia is distributed in the Old World and Neotropical region [117]. In Madagascar, this genus has $66 \%(2 / 3)$ endemism.

For the genus Culex, the majority of non-endemic species are of African origin and only the subgenus Culex contains a few species occurring outside the African region (species belonging to the groups Univittatus and Pipiens). Culex 
species, endemic to Madagascar, belong to five subgenera. Today, there are less than 24\% endemic Culex species in Madagascar and the best known bioclimatic area for this genus is probably the central domain. In contrast, no endemic Culex species are known in the western, northern, and southern domains. There is no doubt that endemicity should be higher in this genus. Already recorded species belong to species complexes, and a revision of genus Culex would likely modify the species inventory in the future.

The genus Mimomyia has a high endemism rate $(77 \% ; 17 /$ 22 ). The subgenus Ingramia is well represented and all species belonging to this subgenus are endemic to Madagascar. The subgenus Etorleptiomyia is found from Africa to the Oriental and South Pacific regions. The subgenus Mimomyia is widely distributed on the African mainland and extends in the east to New Guinea, north-eastern Australia, and the South Pacific [110].

The genus Orthopodomyia is distributed throughout the Afrotropical, Nearctic, Neotropical, Palaearctic, and Oriental regions [117]. However, all Malagasy species of Orthopodomyia are endemic (8/8) and belong only to the Vernoni Group. Because of their morphological homogeneity, these species are probably derived from a single ancestral species [27].

The genus Toxorhynchites with four subgenera is distributed throughout the Afrotropical, Australasian, Neotropical, eastern Palaearctic, and Oriental regions [117]. All Malagasy species of Toxorhynchites are endemic (6/6) and belong only to the subgenus Afrorhynchus. This subgenus evolved here after the separation of Madagascar from the African mainland during the Tertiary period [190].

The genus Uranotaenia is represented by Pseudoficalbia and Uranotaenia subgenera. All species of subgenus Pseudoficalbia are endemic to Madagascar and affinity between Malagasy, African, and Indo-Malaysian species is observed [51]. These authors suggested that the subgenus Pseudoficalbia seems to have appeared in the Madagascar-Indian plate boundary during the Upper Cretaceous. Most species belonging to the subgenus Uranotaenia exhibit a marked affinity with African and Indian species and high endemic components are observed in different sections. Specific radiation seems to have appeared before Gondwana fragmentation [51].

There are no endemic species within the genera Eretmapodites, Ficalbia, Lutzia, and Mansonia. It is important to note that these genera are represented at most by four species. The genus Eretmapodites occurs only in the Afrotropical region, the two Ficalbia species have Afrotropical origin [110]; Lutzia is present in the Neotropical, Asian, Australasian, and African regions and Mansonia has worldwide distribution [117]

\subsection{Bio-indicator species}

According to Leclercq [139], a good bio-indicator should have a specific exigency allowing a link between its presence/absence and environmental particularities. Mosquitoes fit into this definition [62].

\subsubsection{Urban species}

Mosquito species which grow in peri- and para-domestic breeding sites are characteristic of urban areas [240]. Mosquito species growing in several artificial and polluted breeding sites exist in Malagasy urban habitats. It is not surprising to find a high abundance of Cx. quinquefasciatus and Ae. albopictus in Antananarivo, the capital and most urbanized city of Madagascar $[85,176]$ where discarded bottles represent $64 \%$ of household waste [178] and the rice fields of the bottom-land are converted into polluted watercress fields [9].

The same situation is observed in Toamasina, the second largest city in Madagascar, where $C x$. quinquefasciatus and Ae. albopictus have colonized several peri- and para-domestic breeding sites [85]. These species are already considered an urban species in the tropical and south-east Asian regions [240] and in the Mascareignes Archipelago [208].

Ancient entomological data have suggested the presence of Ae. aegypti as a bio-indicator of urban areas in Madagascar [85]. This is however probably not true because its distribution is actually limited to smaller anthropized and/or forested areas [176].

However, An. squamosus and An. coustani are the most abundant Anopheles species in the peripheral areas of the capital city Antananarivo [85], and in the suburban areas of the eastern and central domains where rice fields are abundant in and around cities $[85,210]$.

A study performed in the Morondava region showed the abundance and concomitant presence of Ma. uniformis and Ma. africana in the cities of the western domain [85]. Indeed, all western plains, including within and on the outskirts of cities, are dotted with numerous swamps and ponds [36] which are typical habitats of these two species. These species constitute a major nuisance in some cities of south-east Asia and on the African mainland [240].

\subsubsection{Forested and rural species}

In total, 78 species are restricted to the rainforest biotope and can be considered as bio-indicator of this habitat. Mosquito species belonging to Anopheles of the Neomyzomyia series [108, 112], Aedeomyia (Aedeomyia) madagascarica [33], Aedes (Aedimorphus) albodorsalis [86], Aedes (Diceromyia) sylvaticus [26], and endemic species of Mimomyia (Ingramia) $[66,110]$ were collected only in rainforest habitats. Unlike other follow-up studies [85, 227], Cx. pipiens was abundant only in the Anorana rainforest in the central domain [210]. Because of its abundance, $C x$. pipiens could be considered as a bio-indicator of the rainforest habitat in the central domain. This finding raises important questions regarding the differentiation history or behavior modification of $C x$. pipiens in relation to urban and suburban habitats [123, 180, 227]. Little information is available about its biology in Madagascar, even though a much lower proportion of this species was reported in the Andasibe rainforest of the eastern domain [85].

Several studies have reported that mosquito species of $\mathrm{Fi}$ calbia, Toxorhynchites, Mimomyia (Ingramia), and large numbers of Uranotaenia genera (especially subgenus Pseudoficalbia) occur only in the eastern region. These species lay their eggs in phytothelm breeding sites (Typhonodorum, Ravenala, Pandanus, and Nepenthes madagascarensis) which are characteristic of the eastern domain $[35,122,136]$. These 
observations confirm that these mosquito genera could be considered as good indicators of the eastern domain.

Eretmapodites quinquevittatus is considered as indicator species of degraded areas in all domains, with the exception of the central domain where this species is rare [85]. Four species Aedes brygooi, Ae. coulangesi, Ae. albiradius, and Ae. aegypti are confined to the driest forest of the western domain. In this domain, Ae. fryeri and Ae. cartroni species seem to be related to the presence of mangrove [182]. Anopheles merus was also found in dry regions in the western domain and far south-east of Madagascar and is probably associated with salt-water.

Few species are strongly represented in the warmer and dryer areas of the western domain, even though they occur in others domains: Ae. coulangesi, Ae. durbanensis, Ae. brygooi, Ae. albocephalus, Ae. tiptoni, Ae. cartroni, Cx. tritaeniorhynchus, and Ur. anopheloides are abundant in this area $[31,85,182,194]$. Similarly, Ae. scatophagoides is present only in the semi-arid Androy region, in the southern domain [182], while Ae. ambreensis occurs only in the northern domain [85]. These observations allow us to consider these species bio-indicators of their corresponding geographical domains.

\subsection{Mountain species}

Few species have been caught in mountainous areas, at $1500 \mathrm{~m}$ asl, and could be considered as characteristic of this biotope. These species are Uranotaenia andavakae [65], Ur. dumonti [64], Ur. hamoni [112], Ur. pauliani [64], An. griveaudi [106], and Orthopodomyia ankaratrensis [27]. Of these, only four species are strictly endemic to high mountains (the Ankaratra and Ambohiby mountains near Tsiroanomandidy).

\section{Conclusion}

In Madagascar, up to February 2016, 235 mosquito species belonging to 14 genera have been reported, with a high level of endemism. There is no doubt that this inventory will change with new species. The taxonomic status of species complexes described from only one specimen or from one stage should be deciphered. Further description of species belonging especially to the genus Hodgesia, and the subgenus Culex (Eumelanomyia), should be carried out to complete this inventory.

Acknowledgements. We thank Prof. Steven Goodman, Dr. Philippe Boussès, and Dr. Nohal Elissa for scientific discussions about the south-western Indian Ocean culicidian fauna. This study was conducted as part of the RIFT-OI research project on emerging infectious diseases transmitted by arthropod vectors in the geographical area of the Indian Ocean, and financed by the Centre de Recherche et de Veille sur les maladies émergentes dans l'Océan Indien (CRVOI) and the Institut Pasteur de Madagascar.

\section{References}

1. Adam F, Digoutte JP. 2005. Virus d'Afrique (Base de Données). Centre Collaborateur OMS de Référence et de Recherche pour les Arbovirus et les Virus de Fièvres Hémorrhagiques (CRORA) Dakar, Institut Pasteur de Dakar: Sénégal, Available from: http://www.pasteur.fr/recherche/banques/CRORA/.

2. Adham F, Yaman AS, Mehlhorn H. 2012. Scanning electron microscopic studies on eggsurface morphology and morphometrics of Culex pipiens pipiens (Lin.) (northern house mosquito) and Culex quinquefasciatus (Say) (southern house mosquito) (Diptera: Culicidae). Journal of the Egyptian Society of Parasitology, 42(2), 397-404.

3. Adugna N, Petros B, Woldegiorgis M, Tilahun D, Lulu M. 1998. A study of the status of An. tenebrosus (Donitz, 1902) in the transmission of malaria in Sille, Southern Ethiopia. Ethiopian Journal of Health Development, 12, 75-80.

4. Andriamandimby S, Viarouge C, Ravalohery J, Reynes J, Sailleau C, Tantely M, Elissa N, Cardinale E, Sall A, Zientara S, Héraud. JM. 2015. Detection in Madagascar and circulation of Bluetongue virus among domestic ruminants in Madagascar. Veterinary Microbiology, 176, 268-273.

5. Arim: Arthropodes d'Intérêt Médical, Available from: https:// arim.ird.fr/, accessed on November 2015

6. Armstrong PM, Andreadis TG, Anderson JF, Main AJ. 2005. Isolations of Potosi virus from mosquitoes (Diptera: Culicidae) collected in Connecticut. Journal of Medical Entomology, 42, 875-881.

7. Attoui H, Jaafar FM, Belhouchet M, Aldrovandi N, Tao S, Chen B, Liang G, Tesh RB, de Mico P, de Lamballerie X. 2005. Yunnan orbivirus, a new orbivirus species isolated from Culex tritaeniorhynchus mosquitoes in China. Journal of General Virology, 86, 3409-3417.

8. Aubé-Maurice B, Gingars D, Labbé Y. 2005. Étude de l'impact stratégique du plan d'intervention gouvernemental de protection de la santé publique contre le virus du Nil occidental. Rapport sectoriel 1: problématique du virus du Nil occidental. Bibliothèque et Archive Nationales du Québec Rapport, 1-88

9. Aubry C, Ramamonjisoa J, Dabat M-H, Rakotoarisoa J, Rakotondraibe J, Rabeharisoa L. 2011. Urban agriculture and land use in cities: an approach with the multi-functionality and sustainability concepts in the case of Antananarivo (Madagascar). Land Use Policy, 29, 429-439.

10. Ba Y, Diallo D, Dia I, Diallo M. 2006. Comportement trophique des vecteurs du virus de la fièvre de la vallée du Rift au Sénégal: implications dans l'épidémiologie de la maladie. Bulletin de la Société de Pathologie Exotique, 99, 283-289.

11. Becker T. 1903. Aegyptische Dipteren. Mitteilungen aus dem Zoologischen Museum in Berlin, 2, 67-195.

12. Bigot MJ. 1859. Diptères de Madagascar. Annales de la Société Entomologique de France, 3, 115-135.

13. Boreham PFL, Chandlera JA, Hightona RB. 1975. Studies on the feeding patterns of mosquitoes of the genera Ficalbia, Mimomyia and Uranotaenia in the Kisumu area of Kenya. Bulletin of Entomological Research, 65, 69-74.

14. Boussès P, Brunhes J. 2013. Trois nouveaux Uranotaenia Lynch Arribálzaga de Madagascar (Diptera, Culicidae). Bulletin de la Société Entomologique de France, 118, 399-410.

15. Boyer S, Tantely ML, Randriamaherijaona S, Andrianaivolambo L, Cardinale E. 2014. Mosquitoes sampling strategy for studying West Nile Virus vectors in Madagascar: abundance, distribution and methods of catching in high risk areas. Archives de 1'Institut Pasteur de Madagascar, 71, 1-8.

16. Brengues J, Subra R, Mouchet J, Nelson GS. 1968. La transmission de Wuchereria bancrofti Cobbold en Afrique occidentale. Étude préliminaire d'un foyer de savane nord- 
guinéenne. Bulletin de l'Organisation Mondiale de la Santé, 38, 595-608.

17. Brottes H, Rickenbach A, Brès P, Salaün JJ, Ferrara L. 1966. Les arboviroses au Cameroun. Isolements à partir des moustiques. Bulletin de l'Organisation Mondiale de la Santé, 35, 811-825.

18. Brunhes J. 1967. Contribution à l'étude des Culicidés de Madagascar. Description des larves et de nymphes de Culex (C.) giganteus ventrillon et de Culex (C.) argenteopunctatus Ventrillon. Notes complémentaires sur les adultes de ces deux espèces. Cahiers ORSTOM Série Entomologie médicale et Parasitologie, 5, 207-216.

19. Brunhes J. 1968. Contribution à l'étude des Culicidés de Madagascar. Synonymie entre Culex (N.) seyrigi Edwards 1941 et Culex (N.) robici Doucet 1960; description de la nymphe et de la femelle de Culex (N.) seyrigi Edwards. Cahiers ORSTOM Série Entomologie Médicale et Parasitologie, 6, 15-18.

20. Brunhes J. 1969. Nouvelles données sur les vecteurs de Wuchereria bancrofti à Madagascar. Bulletin de l'Organisation Mondiale de la Santé, 40, 763-769.

21. Brunhes J. 1969. Culicidés de Madagascar: IV. Description des imagos, de la nymphe et de la larve de Culex (Culiciomyia) pandani sp. n. Cahiers ORSTOM Série Entomologie Médicale et Parasitologie, 7, 175-180.

22. Brunhes J. 1971. Culicidés de Madagascar V, Quelques Aedes (sous-genre Finlaya) de Madagascar. Cahiers ORSTOM, Série Entomologie Médicale et Parasitologie, 9, 335-349.

23. Brunhes J. 1972. Épidémiologie de la filariose de Bancroft à Madagascar. II. Recherches sur Wuchereria voceli Galliard, 1959 et étude morphologique comparée des souches malgache et comorienne de Wuchereria bancrofti Cobbold, 1877. Cahiers ORSTOM Série Entomologie Médicale et Parasitologie, 10, 193-205.

24. Brunhes J. 1977. Les moustiques de l'archipel des Comores. I. - Inventaire, répartition et description de quatre espèces ou sous-espèces nouvelles. Cahiers ORSTOM Série Entomologie Médicale et Parasitologie, 15, 131-152.

25. Brunhes J. 1977. Les moustiques de 1'archipel des Comores II. - Description de quatre espèces nouvelles ou peu connues. Répartition des membres du sous-genre Skusea dans l'Océan Indien occidental. Affinité de la faune culicidienne des Comores. Cahiers ORSTOM série Entomologie médicale et Parasitologie, 15, 153-170.

26. Brunhes J. 1982. Culicidés de Madagascar IX. Compléments à la description d'Aedes (Diceromyia) grassei Doucet, 1951 et description d'Aedes (Diceromyia) sylvaticus n. sp. (Diptères, Nématocères). Cahiers ORSTOM série Entomologie médicale et Parasitologie, 20, 313-318.

27. Brunhes J, Hervy JP. 1995. Insectes Diptères Culicidae Culicinae Genre Orthopodomyia de la sous-région malgache et de la région afrotropicale. Faune de Madagascar $n^{\circ} 85$. Éditions du Muséum National d'Histoire Naturelle: Paris.

28. Brunhes J, Rambelo J. 1968. Contribution à l'étude des Culicides de Madagascar. Description des adultes, nymphe et larve de Culex (Neoculex) chauveti. Cahiers ORSTOM série Entomologie médicale et Parasitologie, 6, 113-118.

29. Brunhes J, Ravaonjanahary C. 1971. Culicidés de Madagascar: VI. Description de Culex (Culex) carleti. Cahiers ORSTOM Série Entomologie Médicale et Parasitologie, 9, 177-182.

30. Brunhes J, Ravaonjanahary C. 1973. Culicidés de Madagascar. VII. Description des imagos, de la nymphe et de la larve de
Culex (Eumelanomyia) brenguesi sp. Cahiers ORSTOM Série Entomologie Médicale et Parasitologie, 11, 169-173.

31. Brunhes J, Razafindrasolo E. 1975. Culicidés de Madagascar VIII. Description des imagos, de la nymphe et de la larve d'Uranotaenia (Uranotaenia) anopheloides sp. n. Cahiers ORSTOM Série Entomologie Médicale et Parasitologie, 13, 223-227.

32. Brunhes J, Le Goff G, Geoffroy B. 1998. Anophèles afrotropicaux. II - Mises au point sur les espèces de la sous-région malgache (Diptera, Culicidae). Bulletin de la Société Entomologique de France, 103, 139-152.

33. Brunhes J, Boussès $P$, da Cunha Ramos H. 2011. Les Aedeomyia Theobald, 1901, des régions afro-tropicale et malgache (Diptera, Culicidae). Bulletin de la Société Entomologique de France, 116, 99-128.

34. Bryant JE, Crabtree MB, Nam VS, Yen NT, Duc HM, Miller BR. 2005. Short report: isolation of arboviruses from mosquitoes in northern Vietnam. American Society of Tropical Medicine and Hygiene, 73, 470-473.

35. Callmander MW, Laivao MO. 2002. Endémisme et biogéographie du genre Pandanus (Pandanaceae) en Afrique et à Madagascar. Bioterre, Revue internationale des Sciences de la Vie et de la Terre, no spécial, Actes du colloque international, Centre Suisse du 27-29 août 2001, 76-89.

36. Chauvet G. 1969. Répartition et écologie du complexe Anopheles gambiae à Madagascar. Cahiers ORSTOM série Entomologie médicale et Parasitologie, 7, 235-278.

37. Chauvet G, Déjardin J. 1968. Caractères chétotaxiques de distinction entre larves (stade IV) de l'espèce A et de l'espèce B du complexe Anopheles gambiae. Cahiers ORSTOM Série Entomologie Médicale et Parasitologie, 6, 70-101.

38. Chow VTK, Chan YC, Yong R, Lee KM, Lim LK, Lam-Phua SG, Tan BT. 1998. Monitoring of dengue viruses in field-caught Aedes aegypti and Aedes albopictus mosquitoes by a typespecific polymerase chain reaction and cycle sequencing. American Journal of Tropical Medecine and Hygiene, 58, $578-586$.

39. Christophers SR. 1924. Provisional list and reference catalogue of the Anophelini. Indian Medical Research Memoirs, 3, $1-105$.

40. Clerc Y, Coulanges P. 1979. Rapport du laboratoire d'Arbovirus pour 1978. Archives de 1'Institut Pasteur de Madagascar, 47, 64-68.

41. Clerc Y, Coulanges P. 1980. Rapport du service de virologie. Archives de l'Institut Pasteur de Madagascar, 48, 65-68.

42. Coetzee M, Hunt RH, Wilkerson R, Della Torre A, Coulibaly MB, Besansky NJ. 2013. Anopheles coluzzii and Anopheles amharicus, new members of the Anopheles gambiae complex. Zootaxa, 3619, 246-274.

43. Coluzzi M, Petrarca V, Di Deco MA. 1985. Chromosoma inversion integration and incipient speciation in Anopheles gambiae. Italian Journal of Zoology, 52, 45-63.

44. Coluzzi M, Sabatini A, della Torre A, Di Deco MA, Petrarca V. 2002. A polytene chromosome analysis of Anopheles gambiae species complex. Science, 298, 1415-1418.

45. Cordellier R, Geoffroy B. 1976. Les moustiques de la République Centrafricaine. Travaux et Documents, ORSTOM: Paris. p. 105.

46. Cornet A. 1974. Essai de cartographie bioclimatique à Madagascar, carte à 1/2000 000 et notice. Éditions ORSTOM: Paris. 
47. Cornet M, Robin Y, Chateau R, Hème G, Adam C, Valade M, Le Gonidec G, Jan C, Renaudet J, Dieng PL, Bangoura JF, Lorand A. 1979. Isolements d'arbovirus au Sénégal Oriental à partir de moustiques (1972-1977) et notes sur l'épidémiologie des virus transmis par les Aedes, en particulier du virus amaril. Cahier ORSTOM série Entomologie médicale et Parasitologie, 3, 149-163.

48. Coulanges P, Sureau P, Robin Y, Rodhain F, Mayoux A, Smets P, Ranaivosata J. 1977. État actuel des recherches sur les arbovirus à Madagascar. Archives de l'Institut Pasteur de Madagascar, 46, 113-163.

49. Coz J, Grjebine A, Hamon J. 1960. Anopheles flavicosta Edwards, 1911 de Madagascar et d'Afrique. Bulletin de la Société de Pathologie Exotique, 53, 742-751.

50. da Cunha Ramos H, Ribeiro H. 1975. Research on the mosquitoes of Angola (Diptera: Culicidae). Instituto de Higiene e Medicina Tropical, 2, 111-141.

51. da Cunha Ramos H, Brunhes J. 2004. Insecta, Diptera, Culicidae, Uranotaenia. Collection Faune de Madagascar $\mathrm{n}^{\circ}$ 91. Éditions IRD, CIRAD, Muséum National d'Histoire Naturelle: Paris. p. 461.

52. de Meillon B. 1931. Illustrated keys to the full-grown larvae adults of South African anopheline mosquitos. Publications of the South African Institute for Medical Research, 4, 275-375.

53. De Meillon B. 1943. New records, and new species of Nematocera (Diptera) from the Ethiopian region. Journal of the Entomological Society of Southern Africa, 6, 90-113.

54. De Meillon B. 1947. New records and species of biting insects from the Ethiopian region. II. Journal of the Entomological Society of Southern Africa, 10, 110-124.

55. Delatte H, Paupy C, Dehecq JS, Thiria J, Failloux AB, Fontenille D. 2008. Aedes albopictus, vecteur des virus du chikungunya et de la dengue à la Réunion: biologie et controle. Parasite, 15, 3-15.

56. Diallo D, Sall A, Diagne C, Faye O, Faye O, Ba Y, Hanley K, Buenemann M, Weaver S, Diallo M. 2014. Zika virus emergence in mosquitoes in southeastern Senegal, 2011. PLoS One, 9(10), e109442.

57. Diallo M, Thonnon J, Traore-Lamizana M, Fontenille D. 1999. Vectors of chikungunya virus in Senegal: Current data and transmission cycles. American Journal of Tropical Medicine and Hygiene, 60, 281-286.

58. Diallo M, Nabeth P, Ba K, Sall AA, Ba Y, Mondo M, Girault L, Abdalahi MO, Mathiot C. 2005. Mosquito vectors of the 19981999 outbreak of Rift Valley fever and other arboviruses (Bagaza, sanar, Wesselsbron and West Nile) in Mauritania and Senegal. Medical and Veterinary Entomology, 19, 119-126.

59. Dick G, Haddow A. 1952. Uganda S virus. A hitherto unrecorded virus isolated from mosquitoes in Uganda. (I). Isolation and pathogenicity. Transaction of the Royal Society of Tropical Medicine and Hygiene, 46, 600-618.

60. Dohm DJ, Logan TM, Barth JF, Turell MJ. 1995. Laboratory transmission of Sindbis virus by Aedes albopictus, Aedes aegypti and Culex pipiens (Diptera: Culicidae). Journal of Medical Entomology, 32, 818-821.

61. Dönitz W. 1902. Beiträge zur Kenntniss der Anopheles. Zeitschrift für Hygiene, 41, 15-88.

62. Dorvillé LFM. 1996. Mosquitoes as bioindicators of forest degradation in southeastern brazil, a statistical evaluation of published data in the literature. Studies on Neotropical Fauna and Environment, 31, 68-78.
63. Doucet JP. 1949. Étude des Culicidae (Diptera) du Lac Alaotra, 2. Mémoire de l'Institut Scientifique de Madagascar, série A, 3, 121-145.

64. Doucet JP. 1949. Recherche sur les Culicidae de Madagascar. Mémoire de l'Institut Scientifique de Madagascar, série A Tome III, 325-332.

65. Doucet JP. 1950. Les Culicines de Madagascar (Diptère). Mémoire de l'Institut Scientifique de Madagascar, sér., 4, 39-65.

66. Doucet JP. 1951. Les moustiques de la région de Périnet. Mémoire de l'Institut Scientifique de Madagascar, série, 6, 63-82.

67. Doucet JP. 1951. Étude des Culicidae de la région de Vangaindrano (Diptera). Mémoire de l'Institut Scientifique de Madagascar, A.6, 83-113

68. Doucet JP. 1951. Les Anophélinés de la région Malgache. Mémoire de l'Institut Scientifique de Madagascar. p. 1-198

69. Duchemin J-B, Léong Pok Tsy JM, Rabarison P, Roux J, Coluzzi M, Costantini C. 2001. Zoophily of Anopheles arabiensis and An. gambiae demonstrated by odour-baited entry traps. Medical and Veterinary Entomology, 15, 50-57.

70. Duchemin JB, Ravoahangimalala OR, Le Goff G. 2003. Culicidae, mosquitoes, Moka Gasy, in Natural history of Madagascar, Goodman SM, Benstead J-P, Editors. University of Chicago Press: Chicago, Illinois. p. 708-715.

71. Dyar HG. 1905. Remarks on genitalic genera in the Culicidae. Proceedings of the Entomological Society of Washington, 7, 42-49.

72. Edwards FW. 1911. Some new West African species of Anopheles (sensu lato), with notes on nomenclature. Bulletin of Entomological Research, 2, 141-143.

73. Edwards FW. 1912. A synopsis of the species of African Culicidae, other than Anopheles. Bulletin of Entomological Research, 3(1), 1-53.

74. Edwards FW. 1920. Mosquito notes. Bulletin of Entomology Research, 10, 129-137.

75. Edwards FW. 1920. Notes on the mosquitoes of Madagascar, Mauritius and Reunion. Bulletin of Entomology Research, 11, 133-138.

76. Edwards FW. 1922. Mosquito notes - III. Bulletin of Entomology Research, 13, 75-102.

77. Edwards FW. 1926. Mosquito notes - VI. Bulletin of Entomological Research, 17, 101-131.

78. Edwards FW. 1932. Genera Insectorum. Diptera. Fam. Culicidae. Belgium Fascicule, 194, 1-258.

79. Edwards FW. 1935. Mosquito notes-XII. Bulletin of Entomological Research, 26, 127-136.

80. Edwards FW. 1941. Mosquitoes of the Ethiopian Region. Culicine adults and pupal stage. The British Museum Natural History: London. p. 498.

81. Enderlein G. 1920. Die culiciden-fauna Madagascar. Wiener Entomologische Zeitung, 38, 47-52.

82. Enderlein G. 1923. Zur Kenntnis afrikanischer und orientalischer Culiciden. Wiener Entomologische Zeitung, 40, 25-29.

83. Favia G, Lanfrancotti A, Spanos L, Sidén-Kiamos I, Louis C. 2001. Molecular characterization of ribosomal DNA polymorphisms discriminating among chromosomal forms of Anopheles gambiae s.s. Insect Molecular Biology, 10, 19-23.

84. Fisher B. 2003. Formicidae, Ants, in Natural history of Madagascar, Goodman SM, Benstead J-P, Editors. The University of Chicago Press: Chicago, Illinois. p. 811-819. 
85. Fontenille D. 1989. Arbovirus transmission cycles in Madagascar. Archives de l'Institut Pasteur de Madagascar, $55,1-317$.

86. Fontenille D, Brunhes J. 1984. Trois nouveaux culicidés de Madagascar: Aedes (Aedimorphus) albodorsalis n. sp., Aedes (Aedimorphus) masoalensis n. sp., Aedes (Aedimorphus) mathioti n. sp. Cahiers ORSTOM série Entomologie médicale et Parasitologie, 22, 151-155.

87. Fontenille D, Campbell GH. 1992. Is Anopheles mascarensis a new malaria vector in Madagascar? American Journal of Tropical Medicine and Hygiene, 46, 28-30.

88. Fontenille D, Jupp PG. 1989. Présence du moustique Culex (Culex) neavei à Madagascar, conséquence dans la transmission des arbovirus. Archives de 1'Institut Pasteur de Madagascar, 56, 287-295.

89. Fontenille D, Mathiot C. 1984. Résultats d'une année (1983) d'enquêtes entomologiques sur les vecteurs d'arboviroses à Madagascar. Archives de l'Institut Pasteur de Madagascar, 51, 161-202.

90. Fontenille D, Mathiot C, Rodhain F, Coulanges P. 1988. Les arboviroses dans l'île de Nosy-Be données sérologiques et entomologiques. Archives de 1'Institut Pasteur de Madagascar, 54, 101-115.

91. Fontenille D, Lepers JP, Campbell GH, Coluzzi M, Rakotoarivony I, Coulanges P. 1990. Malaria transmission and vector biology in Manarintsoa, high plateaux of Madagascar. American Journal of Tropical Medicine and Hygiene, 43, 107-115.

92. Fontenille D, Diallo D, Mondo M, Ndiaye M, Thonnon J. 1997. First evidence of natural vertical transmission of yellow fever virus in Aedes aegypti, its epidemic vector. Transactions of the Royal Society of Tropical Medicine and Hygiene, 91, 533-535.

93. Fontenille D, Traore-Lamizana M, Diallo M, Thonnon J, Digoutte JP, Zeller HG. 1998. New vectors of Rift Valley fever in West Africa. Emerging Infectious Diseases, 4, 289-293.

94. Gerhardt RR, Gottfried KL, Apperson CS, Davis BS, Erwin PC, Smith AB, Panella NA, Powell EE, Nasci RS. 2001. First isolation of La Crosse virus from naturally infected Aedes albopictus. Emerging Infectious Diseases, 7, 807-811.

95. Giles GM. 1900. Addendum I. Description of two species of Anopheles from West Africa. Memoirs of the Liverpool School of Tropical Medicine, 2, 49-51.

96. Giles GM. 1901. A plea for the collective investigation of Indian Culicidae with suggestions as to moot points for enquiry, and a prodromus of species known to the author. Journal of the Bombay Natural History Society, 13, 592-610.

97. Giles GM. 1902. A handbook of the gnats or mosquitoes giving the anatomy and life history of the Culicidae, together with descriptions of all species noticed up to the present date. Second edition. John Bale, Sons \& Danielsson Ltd: London.

98. Gillies MT, de Meillon B. 1968. The Anophelinae of Africa south of the Sahara (Ethiopian zoogeographical region). Publications of the South African Institute for Medical Research, 54, 1-343.

99. Girod R, Le Goff G. 2006. Inventaire actualisé des moustiques (Diptera : Culicidae) des îlots français de Europa, Juan-de-Nova et Grande-Glorieuse (Canal du Mozambique, Océan Indien). Bulletin de la Société de Pathologie Exotique, 99, 122-128.

100. Goodman SM, Benstead JP. 2005. Short communication: updated estimates of biotic diversity and endemism for Madagascar. Oryx, 39, 73-77.
101. Gordon SW, Tammariello RF, Linthicum KJ, Dohm DJ, Digoutte JP, Calvo-Wilson MA. 1992. Arbovirus isolations from mosquitoes collected during 1988 in the Senegal River basin. American Journal of Tropical Medicine and Hygiene, $46,742-748$.

102. Gough LH. 1909. On a collection of Anopheles made at Onderstepoort in the autumn of 1909. Report of the Government Veterinary Bacteriologist for the year 1908-09, Transvaal Department of Agriculture, 1908-1909, 115-121.

103. Grjebine A. 1953. Observations sur les nématocères vulnérants de Madagascar, Régions de Majunga et de la Mandraka. Mémoire de l'Institut Pasteur de Madagascar, série E, 4, 443-503.

104. Grjebine A. 1953. Une nouvelle espèce d'Anopheles de Madagascar (Dipt. Culicidae), Anopheles grassei n. sp. Le Naturaliste Malgache, 5, 203-209.

105. Grjebine A. 1956. Aperçu sommaire du peuplement anophélien de Madagascar. Bulletin de l'Organisation Mondiale de la Santé, 15, 593-611.

106. Grjebine A. 1960. Un nouvel Anophèle de Madagascar, An. griveaudi nov. sp. Bulletin de la Société de Pathologie Exotique, 57, 38-42.

107. Grjebine A. 1964. Anopheles (Neomyzomia) grenieri n. sp. (Diptera, Culicidae), nouvelle espèce de Madagascar. Bulletin de la Société de Pathologie Exotique, 57, 38-42.

108. Grjebine A. 1966. Insectes Diptères Culicidae Anophelinae. Faune de Madagascar. XXII. Éditions ORSTOM et CNRS: Paris.

109. Grjebine A. 1979. Les moustiques des Nepenthes de Madagascar. Espèces nouvelles du genre Uranotaenia (Diptera, Culicidae). Annales de la Société Entomologique de France (N.S.), 15, 53-74

110. Grjebine A. 1986. Insectes Diptères Culicidae Culicinae Ficalbiini. Faune de Madagascar $n^{\circ} 68$. Muséum National d'Histoire Naturelle: Paris.

111. Grjebine A, Brygoo ER. 1958. Contribution à l'étude des moustiques de la région filarienne de la Côte Sud-est de Madagascar. Archives de l'Institut Pasteur de Madagascar, 9, 291-306.

112. Grjebine A, Lacan A. 1953. Anopheles (Myzomyia) milloti $\mathrm{n}$. sp. In Grjebine, A Observations sur les nématocères vulnérants de Madagascar, Régions de Majunga et de la Mandraka. Mémoire de l'Institut Pasteur de Madagascar, 4, 495-501.

113. Haddow A. 1960. Studies on the biting habits and medical importance of east African mosquitos in the genus Aedes. I. Subgenera Aedimorphus, Banksinella and Dunnius. Bulletin of Entomological Research, 50, 759-779.

114. Hamon J, Sales S, Coz J, Ouedraogo CS, Dyemkouma A, Diallo B. 1964. Observations sur les préférences alimentaires des moustiques de la République de Haute-Volta. Bulletin de la Société de Pathologie Exotique, 57, 1133-1150.

115. Harbach RE. 1988. The mosquitoes of the subgenus Culex in Southwestern Asia and Egypt (Diptera: Culicidae). Contribution of the American Entomological Institute, 24, 1-240.

116. Harbach RE. 2004. The classification of genus Anopheles (Diptera: Culicidae): a working hypothesis of phylogenetic relationships. Bulletin of Entomological Research, 94, 537-553.

117. Harbach RE. 2007. The Culicidae (Diptera): a review of taxonomy, classification and phylogeny. Zootaxa, 1668, 591-638. 
118. Harbach RE. 2012. Culex pipiens: species versus species complex-taxonomic history and perspective. Journal of the American Mosquito Control Association, 28, 10-23.

119. Harbach RE. 2015. Mosquito Taxonomic Inventory. http:// mosquito-taxonomicinventoryinfo/, accessed on September 2015.

120. Harbach RE, Howard TM. 2007. Corrections in the status and rank of names used to denote varietal forms of mosquitoes (Diptera: Culicidae). Zootaxa, 1542, 35-48.

121. Harbach RE, Kitching IJ. 1998. Phylogeny and classification of the Culicidae (Diptera). Systematic Entomology, 23, 327-370.

122. Hladik A, Blanc P, Dumetz N, Jeannoda V, Rabenandrianina N, Hladik CM. 2000. Données sur la répartition géographique $\mathrm{du}$ genre Ravenala et sur son rôle dans la dynamique forestière à Madagascar, in Diversity and Endemism in Madagascar, Lourenço WR, Goodman SM, Editors. Mémoires de la Société de Biogéographie de Paris. p. 93-104.

123. Hoogstraal H, Meegan JM, Khalil GM, Adham FK. 1979. The Rift Valley fever epizootic in Egypt 1977-78. Ecological and entomological studies. Transactions of the Royal Society of tropical Medicine and Hygiene, 73, 624-629.

124. Hopkins GHE. 1952. Mosquitoes of the Ethiopian Region. The British Museum (Natural History): London.

125. Huang YM. 2004. The subgenus Stegomyia of Aedes in the Afrotropical Region with keys to the species (Diptera: Culicidae). Zootaxa, 700, 1-120.

126. Huang YM, Mathis WN, Wilkerson RC. 2010. Coetzeemyia, a new subgenus of Aedes, and a redescription of the holotype female of Aedes (Coetzemyia) fryeri (Theobald) (Diptera: Culicidae). Zootaxa, 2638, 1-24.

127. Hubálek Z, Halouzka J. 1999. West Nile Fever, a reemerging mosquito-borne viral disease in Europe. Emerging Infectious Diseases, 5, 643-650.

128. Johansen CA, Van Den Hurk AF, Ritchie SA, Zborowski P, Nisbet DJ, Paru R, Bockarie MJ, MacDonald J, Drew AC, Khromykh TI, Mackenzie JS. 2000. Isolation of Japanese Encephalitis virus from mosquitoes (Diptera, Culicidae) collected in the western province of Papua New Guinea, 1997-1998. American Journal of Tropical Medecine and Hygiene, 62, 631-638.

129. Jupp PG, Kemp A, Grobbelaar A, Leman P, Burt FJ, Alahmed AM, Al Mujalli D, Khamees A, Swanepoel R. 2002. The 2000 epidemic of Rift Valley fever in Saudi Arabia: mosquito vector studies. Medical and Veterinary Entomologie, 16, 245-252.

130. Kengne P, Le Goff G, Fontenille D. 2009. Molecular genetic investigation of morphological species of members of the Neomelaniconion sub-genus (Diptera: Culicidae: Aedini) from Madagascar using ribosomal internal transcribed spacer 2. Journal of Medical Entomology, 46, 403-407.

131. Knight KL. 1978. Supplement to a catalog of the mosquitoes of the world (Diptera: Culicidae). The Thomas Say Foundation, Entomological Society of America: College Park, MD. p. 107.

132. Knight KL, Stone A. 1977. A Catalog of the mosquitoes of the world (Diptera: Culicidae). Volume VI. The Thomas Say Foundation, Entomological Society of America College Park: College Park, MD. p. 611.

133. Kokernot RH, Heyman CS, Muspratt J, Wolstenhoime B. 1957. Studies on arthropod-borne viruses of Tongaland. V. Isolation of Bunyamwera and Rift Valley fever viruses from mosquitoes. South African Journal of Medical Science, 22, 71-80.

134. Kokernot RH, Mcintosh BM, Worth C, De Sousa J. 1962. Isolation of virus from mosquitoes collected at Lumbo, Mozambique. II. Mossuril virus, a new virus isolated from the Culex (Culex) sitiens Wiedmann group. American Journal of Tropical Medicine and Hygiene, 11, 683-684.

135. Lachaise D, Harry M, Solignac M. 1996. Affinités biogéographiques des Drosophilidae de Madagascar et des îles de l'Océan Indien. In: Lourenço WR (ed.) Biogéographie de Madagascar: Biogeography of Madagascar, ORSTOM: Paris. p. 467-478.

136. Laivao MO, Callmander MW. 2006. Sur les Pandanus (Pandanaceae) à stigmates aillants de la côte est de Madagascar. Adansonia, Sér 3, 28, 267-285.

137. Laveran A. 1900. Sur un Anopheles provenant de Madagascar. Comptes Rendus des Séances de la Société de Biologie (Paris, France), 57, 109-110

138. Laveran A. 1904. Anopheles et paludisme à Madagascar. Prophylaxie du paludisme, principalement dans l'armée. Bulletin de 1'Académie de Médecine, 52, 730-732.

139. Leclercq L. 2001. Intérêt et limites des méthodes d'estimation de la qualité de l'eau. Station scientifique des Hautes-Fagnes: Belgique. p. 75.

140. Le Goff G, Rajaonarivelo E, Duchemin JB, Robert V. 2002. Revue du genre Coquillettidia (Diptera : Culicidae) à Madagascar et description de la larve de Cq. grandidieri (Blanchard, 1905). Archives de l'Institut Pasteur de Madagascar, 68, 100-103.

141. Le Goff G, Randimby FM, Rajaonarivelo V, Laganier R, Léong Pock Tsy JM, Ceianu CS, Duchemin JB, Robert V. 2003. Anopheles mascarensis de Meillon 1947, vecteur de paludisme dans le Moyen-Ouest de Madagascar. Archives de l'Institut Pasteur de Madagascar, 69, 57-62.

142. Le Goff G, Léong Pock Tsy JM, Robert V. 2006. Molecular characterization of the malaria vector Anopheles gambiae s.s. in Madagascar. Medical and Veterinary Entomology, 20, 259-260.

143. Le Goff G, Boussès P, Brunhes J. 2007. Révision des Neomelaniconion Newstead (Diptera : Culicidae) de Madagascar : espèces présentes et description de cinq nouvelles espèces. Annales de la Société Entomologique de France (N.S.), 43, 187, 200.

144. Le Goff G, Boussès P, Julienne S, Brengues C, Rahola N, Rocamora G, Robert V. 2012. The mosquitoes (Diptera: Culicidae) of Seychelles: taxonomy, ecology, vectorial, importance, and identification keys. Parasites and Vectors, 5, 207. doi: 10.1186/1756-3305-5-20.

145. Le Goff G, Goodman SM, Elguero E, Robert V. 2014. Survey of the Mosquitoes (Diptera: Culicidae) of Mayotte. Plos One, 9(7), e100696.

146. Léong Pock Tsy JM, Duchemin JB, Marrama L, Rabarison P, Le Goff G, Rajaonarivelo V, Robert V. 2003. Distribution of the species of the Anopheles gambiae complex and first evidence of Anopheles merus as a malaria vector in Madagascar. Malaria Journal, 2, 1-7.

147. Linthicum KJ, Davies FG, Kairo A, Bailey CL. 1985. Rift Valley fever virus (family Bunyaviridae, genus Phlebovirus). Isolations from Diptera collected during an inter-epizootic period in Kenya. Journal of Hygiene, 95, 197-209.

148. Liu H, Li MH, Zhai YG, Meng WS, Sun XH, Cao YX, Fu SH, Wang HY, Xu LH, Tang Q, Liang GD. 2010. Banna Virus, 
China, 1987-2007. Emerging Infectious Diseases, 16, 514-517.

149. Lourenço WR. 2003. Scorpiones, scorpions, in Natural history of Madagascar, Goodman SM, Benstead J-P, Editors. The University of Chicago Press: Chicago, Illinois. p. 575-579.

150. Lutomiah JL, Koka H, Mutisya J, Yalwala S, Muthoni M, Makio A, Limbaso S, Musila L, Clark JW, Turell MJ, Kioko E, Schnabel D, Sang RC. 2011. Ability of selected Kenyan mosquito (Diptera: Culicidae) species to transmit West Nile virus under laboratory conditions. Journal of Medical Entomology, 48, 1197-1201.

151. Lutwama JJ, Kayondo J, Savage HM, Burkot TR, Miller BR. 1999. Epidemic O'nyong-nyong fever in southcentral Uganda, 1996-1997, Entomologic studies in Bbaale village, Rakai District. American Journal of Tropical Medicine and Hygiene, 61, 158-162.

152. Maquart M, Boyer S, Rakotoharinome VM, Ravaomanana J, Tantely ML, Heraud J, Cardinale E. 2016. High Prevalence of West Nile virus in domestic birds and detection in 2 new potential mosquito vectors in Madagascar. PLoS One, 11, e0147589.

153. Marchette NJ, Garcia R, Rudnick A. 1969. Isolation of Zika virus from Aedes aegypti Mosquitoes in Malaysia. American Journal of Tropical Medicine and Hygiene, 18, 411-415.

154. Marrama L, Laventure S, Rabarison P, Roux J. 1999. Anopheles mascarensis (De Meillon, 1947): vecteur principal du paludisme dans la région de Fort-Dauphin (Sud-est de Madagascar). Bulletin de la Société de Pathologie Exotique, 92, 136-138.

155. Mattingly PF. 1949. Studies on West African Forest mosquitos. Part II. The less commonly occurring species. Bulletin of Entomological Research, 40, 387-402.

156. Mattingly PF, Brown ES. 1955. The mosquitos (Diptera: Culicidae) of the Seychelles. Bulletin of Entomological Research, 46, 69-110.

157. Mattingly PF, Grjebine A. 1958. Revision du genre Ficalbia Theobald et discussion de la position systématique des Ravenalites Doucet (Diptera, Culicidae). Mémoire de l'Institut Scientifique de Madagascar, 9, 259-287.

158. Mattingly PF, McCrae AWR. 1977. Mosquito Eggs XXIX Genus Hodgesia Theobald. Mosquito Systematics, 9, 333-336.

159. McIntosh BM, Brookworth C, Kokernot RH. 1961. Isolation of semliki Forest virus from Aedes (Aedimorphus) argenteopunctatus (Theobald) collected in Portuguese East Africa. Transactions of the Royal Society of Tropical Medicine and Hygiene, 55, 192-198.

160. McIntosh BM, Kokernot RH, Paterson HE, Hons BS, De Meillon B. 1961. Isolation of spondweni virus from four species of culicine mosquitoes and a report of two laboratory infections with the virus. South African Medical Journal, 35, 647-650.

161. McIntosh BM, Weinbren MP, Worth C, Kokernot RH. 1962. Isolation of viruses from mosquitoes collected at Lumbo, Mozambique. III. Isolation of Spondweni virus from Aedes (Ochlerotatus) fryeri (Theobald) and/or Aedes (Aedimorphus) fowleri (d'Emmerez de Charmoy). American Journal of Tropical Medicine and Hygiene, 11, 885-886.

162. McIntosh BM, Jupp PG, Dos Santos ISL, Meenehan GM. 1976. Culex (Eumelanomyia) rubinotus Theobald as vector of Banzi, Germiston and Witwatersrand Viruses I. Isolation of virus from wild populations of C. rubinotus. Journal of Medical Entomology, 12, 637-640.

163. McIntosh BM, Jupp PG, Dossantos I, Meenehan GM. 1976. Epidemics of West Nile and Sindbis Viruses in South Africa with Culex (Culex) univittatus Theobald as vector. South African Journal of Science, 72, 295-300.

164. Meegan JM, Digoutte JP, Peters CJ, Shope RE. 1983. Monoclonal antibodies identify Zinga virus as Rift Valley fever virus. Lancet, 1, 641-641.

165. Miller BR, Nasci RS, Godsey MS, Savage HM, Lutwama JJ, Lanciotti RS, Peters CJ. 2000. First field evidence for natural vertical transmission of West Nile virus in Culex univittatus complex mosquitoes from Rift Valley province, Kenya. American Journal of Tropical Medicine and Hygiene, 62, 240-246.

166. Mitchell CJ, Haramis LD, Karabatsos N, Smith GC, Starwalt VJ. 1998. Isolation of LaCrosse, Cache Valley, and Potosi virus from Aedes mosquitoes (Diptera: Culicidae) collected at used-tire site in Illinois during 1994-1995. Journal of Medical Entomology, 35, 573-577.

167. Monier M. 1937. Caractères de l'anophelisme sur les Plateaux de l'Emyrne. Bulletin de l'Institut Pasteur, Tananarive, $63,651$.

168. Mulligan EJ. 1937. Rift Valley fever. Annual Report of the Veterinary Department:Nairobi, Kenya. p. 60-62.

169. Nepomichene T, Tata E, Boyer S. 2015. Malaria case in Madagascar, probable implication of a new vector, Anopheles coustani. Malaria Journal, 14(475), 1-8 doi: 10.1186/s12936015-1004-9.

170. Nepomichene TNJJ, Elissa N, Cardinale E, Boyer S. 2015. Species diversity, abundance, and host preferences of mosquitoes (Diptera: Culicidae) in two different ecotypes of Madagascar with recent RVFV transmission. Journal of Medical Entomology, 52, 962-969.

171. Njabo K, Cornel A, Bonneaud C, Toffelmier E, Sehgal R, Valkiunas G, Russell A, Smith T. 2011. Nonspecific patterns of vector, host and avian malaria parasite associations in a central African rainforest. Molecular Ecology, 20, 1049-1061.

172. Patton WS. 1905. The culicid fauna of the Aden Hinterland, their haunts and habits. Journal of the Bombay Natural History Society, 16, 623-637.

173. Paulian R. 1961. La zoogéographie de Madagascar et des îles voisines. Faune de Madagascar, 13, 1-481.

174. Prehaud C, Bouloy M. 1997. La fièvre de la vallée du Rift- Un modéle d'étude des fièvres hémorragiques virales. Annales de l'Institut Pasteur, 8, 233-244.

175. Quan PL, Junglen S, Tashmukhamedova A, Conlan S, Hutchison SK, Kurth A, Ellerbrok H, Egholm M, Briese T, Leendertz FH, Lipkin WI. 2010. Moussa virus: A new member of the Rhabdoviridae family isolated from Culex decens mosquitoes in Côte d'Ivoire. Virus Research, 147, $17-24$.

176. Raharimalala FN. 2011. Rôle des moustiques Culicidae, de leurs communautés microbiennes, et des réservoirs vertébrés, dans la transmission d'arbovirus à Madagascar. Thèse, Université Claude Bernard Lyon I (France) et Université d'Antananarivo (Madagascar), p. 186.

177. Raharimalala FN, Ravaomanarivo LH, Ravelonandro $\mathrm{P}$, Rafarasoa LS, Zouache K, Tran-Van V, Mousson L, Failloux AB, Hellard E, Moro CV, Ralisoa OB, Mavingui P. 2012. Biogeography of the two mosquito vectors, Aedes aegypti and 
Aedes albopictus (Diptera, Culicidae) in Madagascar. Parasites and Vectors, 5, 1-10.

178. Raharinjanahary R. 2011. La question des ordures à Antananarivo: une gestion en déséquilibre permanent. MadagascarRevue de Géographie, 47, 43-66.

179. Ralisoa OB. 1996. Biogéographie du complexe Anopheles gambiae de Madagascar, vecteur du paludisme, in Biogéographie de Madagascar. ORSTOM Editions, Collection Colloques et Séminaires: Lourenço WR Paris. p. 523-534.

180. Rasgon JL, Cornel AJ, Scott TW. 2006. Evolutionary history of a mosquito endosymbiont revealed through mitochondrial hitchhiking. Proceeding of the Royal Society B, 273, 1603-1611.

181. Ratovonjato J, Olive MM, Tantely ML, Andrianaivolambo L, Tata E, Razainirina J, Jeanmaire EM, Reynes JM, Elissa N. 2010. Detection, isolation, and genetic characterisation of Rift Valley Fever Virus from Anopheles (Anopheles) coustani, Anopheles (Anopheles) squamosus, Culex (Culex) antennatus of the Haute Matsiatra Region, Madagascar. Vector-Borne and Zoonotic Diseases, 11, 753-759.

182. Ravaonjanahary C. 1978. Les Aedes de Madagascar (DipteraCulicidae). Étude monographique du genre. 2. Biologie d'Aedes (Diceromyia) tiptoni. Travaux et Documents de l'ORSTOM, 87, 1-210.

183. Ravaonjanahary C. 1979. Présence à Madagascar de Culex (Culex) watti Edwards 1920 Description de la larve et de la nymphe de l'espèce. Cahiers ORSTOM Série Entomologie Médicale et Parasitologie, 17, 193-194.

184. Ravaonjanahary C, Brunhes J. 1977. Un nouvel Aedes du genre Skusea découvert de Madagascar : Aedes (Skusea) moucheti sp. n. Cahiers ORSTOM Série Entomologie Médicale et Parasitologie, 15, 213-215.

185. Ravoahangimalala RO, Rakotoarivony HL, Le Goff G, Fontenille D. 2003. Écoéthologie des vecteurs et transmission du paludisme dans la région rizicole de basse altitude de Mandritsara, Madagascar. Bulletin de la Société de Pathologie Exotique, 96, 323-328.

186. Reid JA, Knight KL. 1961. Classification within the subgenus Anopheles (Diptera, Culicidae). Annals of Tropical Medicine and Parasitology, 55, 474-488.

187. Reinert JF. 1999. Descriptions of Zavortinkius, a new subgenus of Aedes, and the eleven included species from the Afrotropical region (Diptera, Culicidae). Contributions of the American Entomological Institute, 31, 1-106.

188. Reinert JF. 2001. Revised list of abbreviations for genera and subgenera of Culicidae (Diptera) and notes on generic and subgeneric changes. Journal of the American Mosquito Control Association, 17, 51-55.

189. Reinert JF. 2009. List of abbreviations for currently valid generic-level taxa in family Culicidae (Diptera). European Mosquito Bulletin, 27, 68-76.

190. Ribeiro H. 2004. Les Toxorhynchites Theobald de Madagascar (Diptera : Culicidae). Annales de la Société Entomologique de France (N.S.), 40, 243-257.

191. Robert V, Le Goff G, Ariey F, Duchemin J-B. 2002. A possible alternative method for collecting mosquito larvae in rice fields. Malaria Journal, 1, 1-4.

192. Rodhain F, Boutonnier A. 1982. Description d'un nouvel Aedes endémique de Madagascar: Ae. (Diceromyia) coulangesi nova species. Archives de l'Institut Pasteur de Madagascar, 49, 193-196.
193. Rodhain F, Boutonnier A. 1983. Description d'un nouvel Aedes du sous-genre Ochlerotatus (Diptera Culicidae) de Madagascar Aedes ambreensis nova species et considérations générales sur les femelles du sous-genre Ochlerotatus dans la région Afro-tropicale. Bulletin de la Société de Pathologie Exotique, 76, 825-833.

194. Rodhain F, Boutonnier A. 1983. Aedes, Subgenus Diceromyia (Diptera: Culicidae) in Madagascar. Mosquito Systematics, $15,330-336$.

195. Rodhain F, Perez C, Ranaivosata J, Clerc Y, Coulanges P. 1980. Rapport de mission entomologique sur les arbovirus en 1979. Archives de l'Institut Pasteur de Madagascar, 48, 53-61.

196. Rudnick A, Hammon WM, Sather GE. 1962. A strain of Sindbis virus isolated from Culex bitaeniorhynchus mosquitoes in the Philippines. American Journal of Tropical Medicine and Hygiene, 11, 546-549.

197. Salaün JJ, Rickenbach A, Brès P, Brottes H, Germain M, Eouzan JP, Ferrara L. 1969. Les arbovirus isolés à partir de moustiques au Cameroun. Bulletin de l'Organisation Mondiale de la Santé, 41, 233-241.

198. Sang R, Kioko E, Lutomiah J, Warigia M, Ochieng C, O'Guinn M, Lee JS, Koka H, Godsey M, Hoel D, Hanafi H, Miller B, Schnabel D, Breiman RF, Richardson J. 2010. Rift Valley fever virus epidemic in Kenya, 2006/2007: the entomologic investigations. American Journal of Tropical Medicine and Hygiene, 83, 28-37.

199. Santiago-Alarcon D, Palinauskas V, Schaefer H. 2012. Diptera vectors of avian Haemosporidian parasites: untangling parasite life cycles and their taxonomy. Biological Reviews, 87, 928-964.

200. Savage HM, Ceianu C, Nicolescu G, Karabatsos N, Lanciotti R, Vladimirescu A, Laiv L, Ungureanu A, Romanca C, Tsai TF. 1999. Entomologic and avian investigations of an epidemic of West-Nile fever in Romania in 1996, with serologic and molecular characterization of a virus isolate from mosquitoes. American Journal of Tropical Medicine and Hygiene, 61, 600-611.

201. Service MW. 1970. Studies on the biology and taxonomy of Aedes (Stegomyia) vittatus (Bigot) (Diptera: Culicidae) in northern Nigeria. Transaction of the Royal Entomological Society of London, 122, 101-143.

202. Sirivanakarn S. 1971. Contributions to the mosquito fauna of Southeast Asia. XI. A proposed reclassification of Neoculex Dyar based primarily on the male terminalia. Contributions of the American Entomological Institute, 7, 62-85.

203. Sirivanakarn S. 1976. Revision of the subgenus Culex in the oriental region (Diptera: Culicidae). Contributions of the American Entomological Institute, 12, 272.

204. Soper FL. 1967. Aedes aegypti and yellow fever. Bulletin de l'Organisation Mondiale de la Santé, 36, 521-527.

205. Suman DS, Shrivastava AR, Parashar BD, Pant SC, Agrawal OP, Prakash S. 2008. Scanning electron microscopic studies on egg surface morphology and morphometrics of Culex tritaeniorhynchus and Culex quinquefasciatus (Diptera: Culicidae). Parasitology Research, 104, 173-176.

206. Takken W, Verhulst NO. 2013. Host preferences of bloodFeeding mosquitoes. Annual Review of Entomology, 58, 433-453.

207. Tantely ML. 2013. Biologie des moustiques vecteurs potentiels du virus de la fièvre de la Vallée du Rift (FVR) à 
Madagascar. Thèse de Doctorat de 3ème Cycle. Université d'Antananarivo, Madagascar. p. 213.

208. Tantely ML, Tortosa P, Alout H, Berticat C, Berthomieu A, Rutee A, Dehecq J-S, Makoundou P, Labbé P, Pasteur N, Weill M. 2010. Insecticide resistance in Culex pipiens quinquefasciatus and Aedes albopictus mosquitoes from La Réunion Island. Insect Biochemistry and Molecular Biology, 40, 317-324.

209. Tantely ML, Rakotoniaina JC, Andrianaivolambo L, Tata E, Fontenille D, Elissa N. 2012. Modification of distribution of Anopheles gambiae, a malaria vector, at high altitude in Madagascar. Journal of Vector Ecology, 37, 402-406.

210. Tantely ML, Rakotoniaina JC, Andrianaivolambo L, Tata E, Razafindrasata F, Fontenille D, Elissa N. 2013. Biology of mosquitoes that are potential vectors of Rift Valley fever virus in different biotopes of the Central Highlands of Madagascar. Journal of Medical Entomology, 50, 603-610.

211. Tantely ML, Cêtre-Sossah C, Rakotondranaivo T, Cardinale E, Boyer S. 2016. Mosquito population dynamics in a WNV endemic context with a specific focus on Aedeomyia madagascarica, a potential acting competent vector. Vector-Borne and Zoonotic Diseases (Submitted).

212. Thavara U, Tawatsin A, Pengsakul T, Bhakdeenuan $P$, Chanama S, Anantapreecha S, Molito C, Chompoosri J, Thammapalo S, Sawanpanyalert P, Siriyasatien P. 2009. Outbreak of chikungunya fever in Thailand and virus detection in field population of vector mosquitoes, Aedes aegypti (L.) and Aedes albopictus Skuse (Diptera: Culicidae). Southeast Asian Journal of Tropical Medicine and Public Health, 50, 951-962.

213. Theobald FV. 1901. The classification of mosquitoes. Journal of Tropical Medicine, 4, 229-235.

214. Theobald FV. 1901. Notes on a collection of mosquitoes from West Africa, and descriptions of new species. Memoirs of the Liverpool School of Tropical Medicine A (App.), 1, 1-14.

215. Theobald FV. 1901. A monograph of the Culicidae of the world. Sub family Culicina Culex continued, Vol. 2, British Museum (Natural History): London p. 391.

216. Theobald FV. 1903. A monograph of the Culicidae of the world. General Notes. London, British Museum (Natural History), 3, 1-359.

217. Theobald FV. 1905. New Culicidae from India, Africa, British Guiana, and Australia. Journal of Economic Biology, 1, $17-36$.

218. Theobald FV. 1906. Report on economic entomology. Part I. Second report on the mosquitoes or Culicidae of the Sudan. Report Wellcome Laboratories, Gordon College, Khartoum, 2, 67-83.

219. Theobald FV. 1907. A monograph of the Culicidae or mosquitoes. Vol. 4, British Museum (Natural History): London. p. 639.

220. Theobald FV. 1910. A monograph of the Culicidae of the world. Vol. V. British Museum (Natural History): London. p. 646.

221. Theobald FV. 1912. No. V.- Diptera, Culicidae. Transactions of the Linnean Society of London, 15, 81-94.

222. Traore-Lamizana M, Zeller HG, Mondo M, Hervy JP, Adam F, Digoutte JP. 1994. Isolations of West Nile and Bagaza viruses from mosquitoes (Diptera: Culicidae) in Central Senegal (Ferlo). Journal of Medical Entomology, 5, 934-938.

223. Traoré-Lamizana M, Zeller H, Monlun E, Mondo M, Hervy JP, Adam F, Digoutte JP. 1994. Dengue 2 outbreak in southeastern Senegal during 1990: virus isolations from mosquitoes (Diptera: Culicidae). Journal of Medical Entomology, 31, 623-627.

224. Traoré-Lamizana M, Fontenille D, Diallo M, Ba Y, Zeller H, Mondo M, Adam F, Thonon J, Maïga A. 2001. Arbovirus surveillance from 1990 to 1995 in the Barkedji Area (Ferlo) of Senegal, a possible natural focus of Rift Valley Fever Virus. Journal of Medical Entomology, 38, 480-492.

225. Turell MJ, Linthicum KJ, Patrican LA, Davies FG, Kairo A, Bailey CL. 2008. Vector competence of selected african mosquito (Diptera: Culicidae) species for Rift Valley fever virus. Journal of Medical Entomology, 45, 102-108.

226. Uilenberg G, Hoogstraal H, Klein J-M. 1979. Les tiques (Ixodoidea) de Madagascar et leur rôle vecteur. Archives de l'Institut Pasteur de Madagascar, 00, 1-153.

227. Urbanelli S, Silvestrini F, Sbabatinelli G, Raveloarifera F, Petrarca V, Bullini L. 1995. Characterization of the Culex pipiens Complex (Diptera: Culicidae) in Madagascar. Journal of Medical Entomology, 32, 778-786.

228. van Someren ECC. 1947. The description of a new Anopheles of the Myzorhynchus series from Madagascar with notes on its systematic position in relation to the Ethiopian species of this group. East African Medical Journal, 24, 42-46.

229. van Someren ECC. 1949. Ethiopian Culicidae, description of four new mosquitoes from Madagascar. Proceedings of the Entomological Society of London, 18, 3-8.

230. van Someren ECC. 1956. Undescribed culicine larvae and pupal stage from Uganda. Transactions of the Royal Entomological Society of London, 25, 1-12.

231. Vanlandingham DL, Hong C, Klingler K, Tsetsarkin K, K1 Mcelroy, Powers AM, Lehane MJ, Higgs S. 2005. Differential infectivities of O'nyong-nyong and Chikungunya virus isolates in Anopheles gambiae and Aedes aegypti mosquitoes. American Journal of Tropical Medicine and Hygiene, 72, 616-621.

232. Ventrillon E. 1904. Description de culicides de Madagascar. Bulletin du Muséum National d'Histoire Naturelle, 10, $550-555$.

233. Ventrillon E. 1905. Culicides nouveaux de Madagascar. Bulletin du Muséum National d'Histoire Naturelle, 11, 427-431.

234. Ventrillon E. 1906. Culicidé nouveau de Madagascar (Stegomyia) cartroni. Bulletin du Muséum National d'Histoire Naturelle, 12, 143-145.

235. Ward RA. 1984. Second supplement to a catalog of the mosquitoes of the world (Diptera: Culicidae). Mosquito Systematics, 16, 227-270.

236. Ward RA. 1992. Third supplement to a catalog of the mosquitoes of the world (Diptera: Culicidae). Mosquito Systematics, 24, 177-230.

237. Weinbren MP, Hons DS, S. MRC, P. LRC, Kokernot RH, Smithburn KC. 1956. Satrins of sindbis-like virus isolated from culicine mosquitoes in the union of south Africa. I. Isolation and Properties. South African Medical Journal, 631-636.

238. White GB. 1975. Notes on a catalogue of Culicidae of Ethiopian Region. Mosquito Systematics, 7: 303-344.

239. WHO. 1951. Rapport de la conférence du Paludisme en Afrique Équatoriale. Organisation Mondiale de la Santé, série de rapports techniques, $38,1-81$.

240. WHO. 1988. Lutte contre les vecteurs et les nuisibles en milieu urbain. WHO série de rapports techniques, 767, 786.

241. Wilkerson RC, Linton Y, Fonseca D, Schultz T, Price D, Strickman D. 2015. Making mosquito taxonomy useful: a 
stable classification of tribe Aedini that balances utility with current knowledge of evolutionary relationships. Plos One, 10, e0133602.

242. Wills WM, Jakob WL, Francy DB, Oertley RE, Anani E, Calisher CH, Monath TP. 1984. Sindbis virus isolations from Saudi Arabian mosquitoes. Transactions of the Royal Society of Tropical Medicine and Hygiene, 79, 63-66.
243. Wilson DB. 1947. Malaria in Madagascar. East African Medical Journal, 24, 171-176.

244. WRBU: Walter Reed Biosystematics Unit, Systematic catalog of Culicidae [Internet]. Smithsonian Institution: Washington, DC, Available from: http://wwwmosquitocatalogorg/files/ pdfs/mq_ClassificationNew201309pdf, 2013.

Cite this article as: Tantely ML, Goff GL, Boyer S \& Fontenille D: An updated checklist of mosquito species (Diptera: Culicidae) from Madagascar. Parasite, 2016, 23, 20.

\section{PARASTE}

An international open-access, peer-reviewed, online journal publishing high quality papers on all aspects of human and animal parasitology

Reviews, articles and short notes may be submitted. Fields include, but are not limited to: general, medical and veterinary parasitology; morphology, including ultrastructure; parasite systematics, including entomology, acarology, helminthology and protistology, and molecular analyses; molecular biology and biochemistry; immunology of parasitic diseases; host-parasite relationships; ecology and life history of parasites; epidemiology; therapeutics; new diagnostic tools.

All papers in Parasite are published in English. Manuscripts should have a broad interest and must not have been published or submitted elsewhere. No limit is imposed on the length of manuscripts.

Parasite (open-access) continues Parasite (print and online editions, 1994-2012) and Annales de Parasitologie Humaine et Comparée (1923-1993) and is the official journal of the Société Française de Parasitologie. 